\title{
Beoordeling mogelijke PAS maatregelen: plausibiliteit van werking AgriMestMix systeem
}





\section{Beoordeling mogelijke PAS maatregelen: plausibiliteit van werking AgriMestMix systeem}

N.W.M. Ogink, R.W. Melse

Dit onderzoek is uitgevoerd door Wageningen Livestock Research, in opdracht van en gefinancierd door het Ministerie van Landbouw, Natuur en Voedselkwaliteit, in het kader van het Beleidsondersteunend onderzoekthema 'PAS (Programmatische Aanpak Stikstof)' (projectnummer BO-20-004-022) 
N.W.M. Ogink, R.W. Melse, 2020. Beoordeling mogelijke PAS maatregelen: plausibiliteit van werking AgriMestMix systeem, Wageningen Livestock Research, Rapport 1233.

\section{Samenvatting NL}

In dit rapport wordt een beoordeling gegeven van de plausibiliteit van de werking van het AgriMestMix systeem als mogelijke maatregel om de ammoniakemissie uit stallen met mestopslag onder de roosters tegen te gaan. De maatregel behelst het dagelijks versproeien van een middel over het oppervlak van de mengmest in de mestkelder. Dit middel bestaat volgens opgave van de leverancier uit een mengsel van mineralen en bacteriën. Op basis van de analyse van de beschikbare informatie wordt geconcludeerd dat er onvoldoende onderbouwing is om te concluderen dat dat de toepassing van de AgriMestMix additieven een emissiereductie van ammoniak uit de stal tot gevolg heeft. De beoordeling is uitgevoerd door Wageningen Livestock Research in opdracht van het Ministerie van Landbouw, Natuur en Voedselkwaliteit.

\section{Summary UK}

In this report an evaluation is given of the plausibility of the effectiveness of the AgriMestMix system as possible measure to reduce the ammonia emission from animal houses with manure storage below slatted floors. The measure is based on daily spraying of a mixture of minerals and bacteria on the manure surface in the manure pit, according to the supplier. Based on the available information it is concluded that insufficient evidence is available to conclude that the use of the AgriMestMix additives will lead to a reduction of the ammonia emission from an animal house. The evaluation was carried out by Wageningen Livestock Research, Netherlands, and commissioned by the Ministry of Agriculture, Nature and Food Quality, Netherlands.

Dit rapport is gratis te downloaden op https://doi.org/10.18174/514812 of op www.wur.nl/livestock-research (onder Wageningen Livestock Research publicaties).

\section{(C) 2020 Wageningen Livestock Research}

Postbus 338, 6700 AH Wageningen, T 03174839 53, E info.livestockresearch@wur.nl, www.wur.nl/livestock-research. Wageningen Livestock Research is onderdeel van Wageningen University \& Research.

Wageningen Livestock Research aanvaardt geen aansprakelijkheid voor eventuele schade voortvloeiend uit het gebruik van de resultaten van dit onderzoek of de toepassing van de adviezen.

Alle rechten voorbehouden. Niets uit deze uitgave mag worden vermenigvuldigd en/of openbaar gemaakt worden door middel van druk, fotokopie, microfilm of op welke wijze dan ook zonder voorafgaande toestemming van de uitgever of auteur.

Wageningen Livestock Research is NEN-EN-ISO 9001:2015 gecertificeerd.

Op al onze onderzoeksopdrachten zijn de Algemene Voorwaarden van de Animal Sciences Group van toepassing. Deze zijn gedeponeerd bij de Arrondissementsrechtbank Zwolle. 


\section{Inhoud}

$\begin{array}{lr}\text { Samenvatting } & \mathbf{5}\end{array}$

$\begin{array}{lr}\text { Summary } & 7\end{array}$

$\begin{array}{llr}1 & \text { Inleiding } & 9\end{array}$

$\begin{array}{llr}2 & \text { Werkwijze } & 10\end{array}$

$3 \quad$ Beoordeling AgriMestMix systeem $r$

3.1 Inleiding $\quad 12$

3.2 Beschrijving systeem en werkingsprincipe 12

$\begin{array}{ll}3.3 & \text { Wetenschappelijk onderzoek en metingen } \\ 3.4 & 14\end{array}$

$\begin{array}{ll}3.4 & \text { Overige aspecten } \\ 3.5 & \text { Discussie en conclusie }\end{array}$

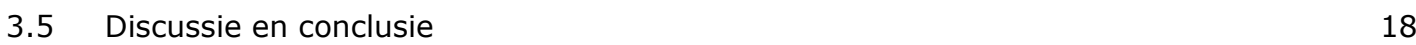

4

$\begin{array}{lr}\text { Bijlagen } & 19\end{array}$

4.1 Brief van leverancier / aanvrager aan WLR met bijlagen en documenten (89 pagina's)

4.2 Samenvatting rapport Blauw (BL2012.5216.02-V04, maart 2013) 109

4.3 Abstract Van Vliet et al., $2006 \quad 112$

4.4 Abstract Van der Stelt et al., $2007 \quad 113$

4.5 Patent WO 2014/104883 A1, verleend aan aanvrager / leverancier
(25 pagina's) 



\section{Samenvatting}

De Programmatische Aanpak Stikstof (hierna: PAS) heeft tot doel economische ontwikkeling mogelijk te maken, de vergunningverlening te vereenvoudigen en natuurdoelen in kader van Natura 2000 te realiseren. Een van de instrumenten om de uitstoot van ammoniak uit de landbouwsector te verminderen is het publiceren van een "overzicht PAS-maatregelen", waarin voer- en managementmaatregelen opgenomen die bewezen effectief en controleerbaar zijn. Door bedrijfsleven en belangenorganisaties is een aantal mogelijke maatregelen onder de aandacht gebracht bij het Ministerie van Landbouw, Natuur en Voedselkwaliteit (LNV) die mogelijk opgenomen zouden kunnen worden in het overzicht PAS-maatregelen. Een van deze maatregelen betreft het zogenaamde AgriMestMix systeem.

Het Ministerie van LNV heeft aan Wageningen Livestock Research (WLR) gevraagd om een beoordeling van de plausibiliteit van de werking van het AgriMestMix systeem uit te voeren op basis van de door de leverancier beschikbaar gestelde informatie en op basis van de geldende wetenschappelijke inzichten. De leverancier heeft er mee ingestemd dat alle aangeleverde informatie openbaar gemaakt wordt.

Het AgriMestMix systeem richt zich op de behandeling van mengmest in een stal met mestopslag onder de roosters. Het systeem bestaat erin dat dagelijks een middel versproeid wordt over het oppervlak van de mengmest in de mestkelder. Dit middel bestaat volgens de leverancier uit een mengsel van mineralen en bacteriën. In het rapport wordt een analyse gemaakt van het mogelijke effect van de toepassing van dit additief, gebaseerd op de door de leverancier aangeleverde informatie en overige wetenschappelijke literatuur.

Uit de analyse blijkt dat het beschreven werkingsmechanisme geen plausibele verklaring geeft voor het terugdringen van ammoniakemissie en tegenstrijdigheden bevat. Daarnaast wordt het beschreven werkingsmechanisme niet ondersteund door effecten op mestsamenstelling in het emissie-onderzoek dat werd uitgevoerd in twee varkensstallen. Verder laat het betreffende emissie-onderzoek geen uitspraken toe over het eventuele effect van het toegediende AgriMestMix omdat in de control-case opzet behandelings- en afdelingseffecten waren verstrengeld.

Op basis van de analyse van de beschikbare informatie wordt geconcludeerd dat er onvoldoende onderbouwing is om te concluderen dat de toepassing van de AgriMestMix additieven een emissiereductie van ammoniak uit de stal tot gevolg heeft.

Een externe, onafhankelijke partij heeft een wetenschappelijke review van het rapport uitgevoerd. 


\section{Summary}

The Dutch Ministry of Agriculture, Nature and Food Quality has commissioned Wageningen Livestock Research to evaluate several possible measures for ammonia emission reduction from animal houses. One of these measures aims to mitigate the ammonia emission from animal houses with manure storage below the slatted floor and is based on the daily spraying of an additive (called AgriMestMix) on the surface of the manure pit. According to the manufacturer, the additive is a mixture of minerals and bacteria.

Based on the information supplied by the manufacturer available scientific literature, the plausibility of the effectiveness of the AgriMestMix additive was evaluated. The manufacturer agreed upon publication of all information that was provided by them.

The evaluation shows that the described working mechanism does not give a plausible explanation for ammonia emission reduction. Furthermore, the described working mechanism is not supported by the findings of the emission research that was performed carried out in two pig compartments. Finally, the performed emission research does not allow any conclusion on the effect of the addition of AgriMestMix as in the control-case setup of the research the treatment and location effects were intertwined.

Based on the available information it is concluded that insufficient evidence is available to conclude that the use of the AgriMestMix addtives will lead to a reduction of the ammonia emission from an animal house.

An external, independent party has carried out a scientific review of this report. 


\section{$1 \quad$ Inleiding}

De Programmatische Aanpak Stikstof (hierna: PAS) heeft tot doel economische ontwikkeling mogelijk te maken, de vergunningverlening te vereenvoudigen en natuurdoelen in kader van Natura 2000 te realiseren. Om dit doel te bereiken moeten alle sectoren hun steentje bijdragen. De bijdrage van de landbouwsector richt zich op het verminderen van de uitstoot van ammoniak via stalmaatregelen, voer- en managementmaatregelen en het uitrijden van dierlijke mest.

Een van de instrumenten om de uitstoot van ammoniak uit de landbouwsector te verminderen is het publiceren van een "overzicht PAS-maatregelen" in bijlage 2 van de Regeling Ammoniak en Veehouderij. In dit overzicht worden voer- en managementmaatregelen opgenomen die bewezen effectief en controleerbaar zijn. Dit betekent dat de uitstoot van ammoniak uit de stal met minimaal $10 \%$ dient te verminderen ten opzichte van de emissiefactor van overige stalsystemen voor de betreffende diercategorie, zoals opgenomen in bijlage 1 van de Rav.

Door bedrijfsleven en belangenorganisaties is een aantal mogelijke maatregelen onder de aandacht gebracht bij het Ministerie van Landbouw, Natuur en Voedselkwaliteit (LNV) die mogelijk opgenomen zouden kunnen worden in het overzicht PAS-maatregelen. Het Ministerie van LNV heeft aan Wageningen Livestock Research (WLR) gevraagd om een beoordeling van de plausibiliteit van de werking van een aantal van deze maatregelen uit te voeren. 


\section{Werkwijze}

Namens het Ministerie van LNV heeft WLR een brief gestuurd aan de bedrijven en organisaties die aangegeven hebben een potentiële PAS maatregel te hebben ontwikkeld of te willen toepassen. In deze brief werd aan de partijen (hierna genoemd: aanvrager) verzocht om nadere informatie over de maatregel te verschaffen.

Verder werd in de brief aangegeven dat WLR op basis van de beschikbaar gestelde informatie en op basis van de geldende wetenschappelijke inzichten zou beoordelen of het aannemelijk is dat de voorgestelde maatregel de uitstoot van ammoniak uit de stal zal verminderen met minimaal $10 \%$. Verzocht werd om aan de hand van een vragenlijst alle relevante informatie in verband met de beoordeling aan te leveren. De vragenlijst was als volgt opgesteld:

1) Kunt u de maatregel kort beschrijven? Ga hierbij s.v.p. in op de grote lijnen van de wijze waarop de maatregel werkt. Geef tevens aan op welke diersoort(en) of diercategorie(ën) de maatregel zich richt,

2) Kunt $u$ het werkingsprincipe van de maatregel in chemische/fysische termen toelichten (incl. relevante reactievergelijking, balansen, wetenschappelijke literatuur etc.) voor wat betreft de beoogde emissiereductie van ammoniak?

3) Is er reeds een indicatieve beoordeling uitgevoerd door een onafhankelijke wetenschappelijk instantie waaruit blijkt dat er voldoende wetenschappelijke informatie voorhanden is die het werkingsprincipe van de maatregel bevestigt en inzicht biedt in de vermindering van de uitstoot van ammoniak? Zo ja, s.v.p. deze informatie bijvoegen.

4) Is de maatregel (mede) gebaseerd op een modelmatige aanpak waarmee de mogelijke emissiereductie wordt berekend? Zo ja, is het gebruikte model wetenschappelijk onderbouwd / geaccepteerd, zijn de gebruikte inputwaarden van de modelparameters realistisch en vallen deze binnen de waarden waarvoor het model geldig is?

5) (Deze vraag is vervallen in verband met incorrecte nummering)

6) Zijn er metingen uitgevoerd in Nederlandse praktijkomstandigheden die het werkingsprincipe van de maatregel bevestigen en die inzicht bieden in de hoogte van de vermindering van de uitstoot van ammoniak. Zo ja, s.v.p. deze informatie bijvoegen.

7) Voor zover nog niet beantwoord onder vraag 4: Zijn er metingen uitgevoerd volgens de huidige meetprotocollen zoals die gehanteerd worden voor opname van een systeem in de Regeling ammoniak en veehouderij (zie http://www.agentschapnl.nl/content/rav-ammoniakemissie-meetprotocol)? Zo ja, s.v.p. deze informatie bijvoegen.

8) Is er sprake van neveneffecten bij toepassing van de maatregel (bijvoorbeeld afwenteling naar andere milieucompartimenten, emissie van broeikasgassen etc.)?

9) Op welke wijze kan naar uw mening de invoering en toepassing van de maatregel worden gecontroleerd en gehandhaafd door het bevoegde gezag? Is er bijvoorbeeld sprake van het vastleggen van relevante procesparameters?

Verder werd in de brief aangegeven:

- dat een concept van de rapportage met de beoordeling van de voorgestelde maatregel zou worden aangeboden aan de aanvrager ter controle op feitelijke onjuistheden;

- dat het Ministerie van LNV aan WLR heeft verzocht om de beoordelingen te publiceren in een openbaar rapport; dit betekent dat de aanvrager ermee instemt dat alle door hem aangeleverde informatie openbaar gemaakt wordt; 
- dat wanneer de aanvrager de ingevulde vragenlijst en eventuele aanvullende informatie aan WLR retourneert, daarmee aangeeft dat hij instemt met deze voorwaarden;

- dat het Ministerie van LNV de beoordeling door WLR vervolgens kan gebruiken om te beslissen om de voorgestelde maatregel al dan niet opgenomen wordt in het "overzicht PAS-maatregelen"; het ministerie zal bij de besluitvorming hierover advies vragen aan de Technische adviescommissie Regeling ammoniak en veehouderij (TacRav).

Een aantal bedrijven heeft hiermee ingestemd en een ingevulde vragenlijst en aanvullende informatie aan WLR toegestuurd. Een van deze bedrijven betreft de leverancier van het mestadditief AgriMestMix. Vervolgens heeft WLR een beoordeling van de plausibiliteit van de werking van het AgriMestMix systeem uitgevoerd en het concept-rapport voorgelegd aan de leverancier. Daarnaast is het concept-rapport voorgelegd aan een externe, onafhankelijke partij, die een wetenschappelijke review van het rapport heeft uitgevoerd.

De reacties hierop zijn, voor zover van toepassing, verwerkt en hebben geleid tot voorliggend rapport. 


\section{Beoordeling AgriMestMix systeem}

\section{$3.1 \quad$ Inleiding}

De beoordeling van het mestadditief AgriMestMix is gebaseerd op de door de leverancier aangeleverde informatie (zie Bijlage 4.1), en op relevante wetenschappelijke inzichten. In de door de leverancier aangeleverde documentatie wordt zowel de benaming AgriMest als AgriMestmix gebruikt en wordt in een aantal gevallen ook de naam van een andere leverancier vermeld.

Aangezien de aanvrager deze documentatie ter ondersteuning van de aanvraag inzendt wordt er in deze beoordeling van uitgegaan dat het hier om hetzelfde product gaat.

\subsection{Beschrijving systeem en werkingsprincipe}

\section{Beschrijving systeem}

Het systeem is gebaseerd op het dagelijks sprayen van een mineralenmengsel (AgriMestMix) over de opgeslagen mest onder de roosters in het dierenverblijf. In Figuur 1 wordt de wijze van dosering in een varkensstal toegelicht. Volgens opgave (Blauw, 2013 ${ }^{1}$ ) dient er dagelijks 15 ml AgriMestMix toegediend te worden (afdelingsgrootte 80-96 dieren).

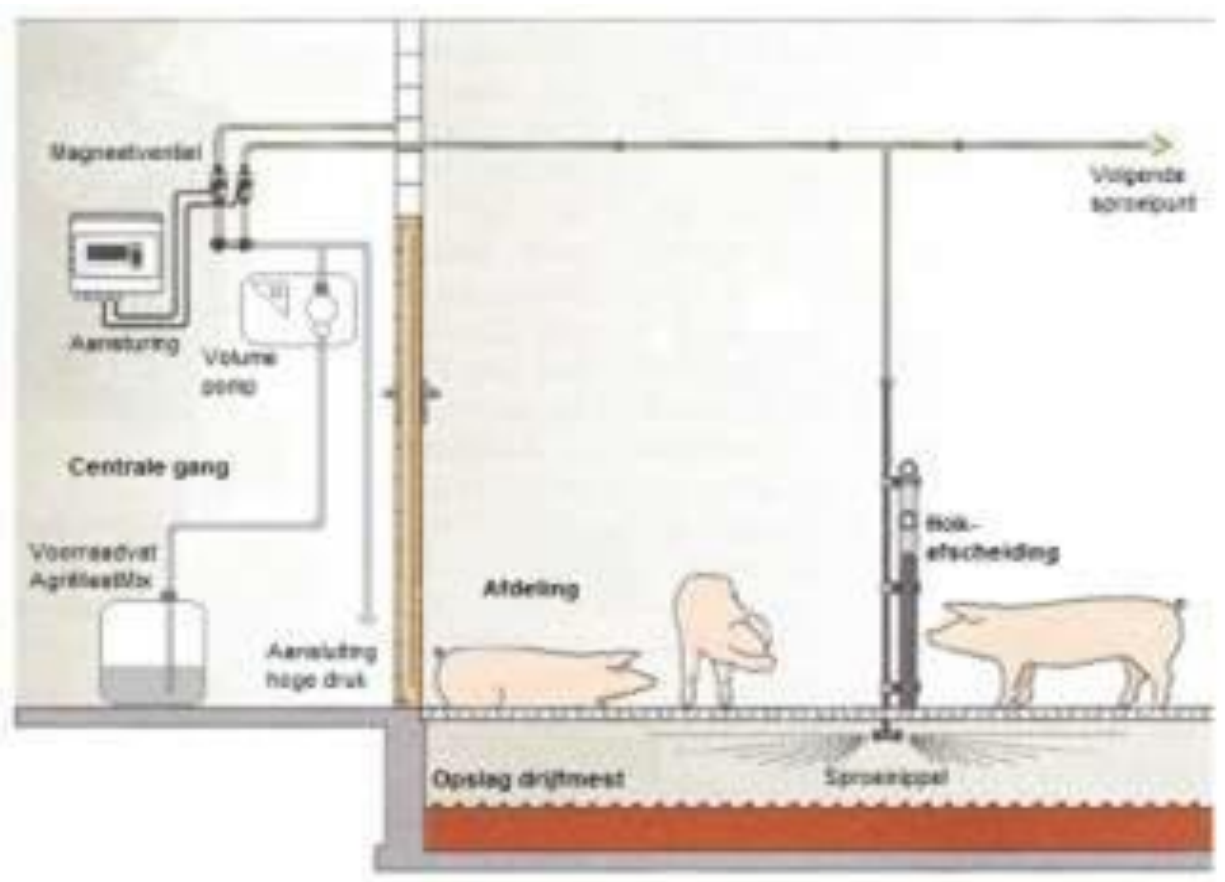

Figuur 1 Toediening van AgriMestMix in een varkensafdeling (bron: rapport Blauw, 2013).

\section{Beschrijving werkingsprincipe}

De aanvrager geeft in een begeleidend schrijven de volgende informatie over het werkingsprincipe. 'AgriMestMix veranderd de biochemische processen in de mest, het natuurlijke mineralenmengsel heeft een sterke remming op de methanogene fase (gasproductie) door het stoppen van het anaerobe proces in de mest en het opstarten van een aerobe proces vindt er een reductie van broeikas gassen plaats zoals ammoniak, methaan en lachgas. (Zie rapporten) Door de reductie van zowel ammoniak,

\footnotetext{
${ }^{1}$ Blauw (2013). Onderzoek ammoniakemissiereductie door installatie van mestbewerking. Case-control metingen bij 2 bedrijven. Rapportnummer: BL2012.5216.02-V04, 27 maart 2013. Bureau Blauw, Wageningen. Het volledige rapport is opgenomen als onderdeel van Bijlage 4.1, een samenvatting van het rapport is opgenomen als Bijlage 4.2.
} 
methaan en lachgas word het verdringing principe bevestigt. Ook als er in de mest een afwenteling plaats vind naar een andere gasvorm bv van ammoniak naar methaan of lachgas dan vind er met de AgriMestMix maatregel een reductie plaats (zie rapport Blauw) Omdat het om een verdringing principe gaat werkt de maatregel in drijfmest van alle diersoorten en vaste mest van alle diersoorten en ander te composteren materialen. Als er AgriMestMix aan de drijfmest word toegevoegd, vind door de processen een afbraak van organisch materiaal plaats, de stikstof die hier bij vrij komt bindt zich net als de andere minerale stikstof aan de kali en de zwavel in de mest, en vormt daardoor een ammoniumnitraat.'

In het door de aanvrager ingezonden meetrapport van het meetbureau Blauw (zie Bijlage 4.1) wordt het werkingsprincipe van AgriMestMix als volgt omschreven in hoofdstuk 2.3:

'De mestbewerkingsinstallatie reduceert de ammoniakuitstoot door dagelijks een hoeveelheid natuurlijk mineralenmengsel te sprayen over de drijfmest. Door dit dagelijks te herhalen verandert het proces in de mest. Hierdoor stopt de gasvorming in de mest en wordt de emissie van onder andere ammoniak sterk gereduceerd. De stikstof blijft in de mest en komt later beschikbaar voor de planten. Het droge stofgehalte van de mest en het organisch stofgehalte nemen door toevoeging van het mineralenmengsel af.

Het natuurlijk mineralenmengsel bestaat uit natuurlijke mineralen, minerale zuurstof en een aantal specifieke specifieke bacteriën. De natuurlijke mineralenmengsel heeft een sterke remming op de methanogene fase (gasproductie). Door het stoppen van het anaerobe proces in de mest en het opstarten van een aerobe proces vindt er een reductie plaats van de ammoniakemissie.'

In het artikel "Effectieve Micro-organismen verbeteren kwaliteit runderdrijfmest niet" uit het vakblad V-Focus (juni 2006, zie Bijlage 4.1) wordt het volgende opgemerkt over de werking van Agri-Mest: "Volgens leverancier Agriton (Noordwolde) bestaat Agri-Mest uit 'geënergetiseerde mineralen die een belangrijke rol spelen bij enkele gecompliceerde biochemische processen'. Agri-Mest kan de omstandigheden in drijfmest zodanig beïnvloeden dat onder ander meer energie beschikbaar komt en micro-organismen een anaërobe fermentatie kunnen uitvoeren. " De resultaten uit dit onderzoek zijn eveneens gepubliceerd in een wetenschappelijk artikel van Vliet et al. $\left(2006^{2}\right.$ ), wat door de aanvrager was bijgevoegd. Hierin wordt het volgende opgemerkt: "According to the company Agriton, Agri-mest contains "energized minerals" and can effect the manure environment in such a manner that "more energy becomes available", which will lead to a better anaerobic fermentation by micro-organisms in the manure."

In een wetenschappelijk artikel van Van der Stelt et al. $\left(2007^{3}\right)$ waarin de werking van Agri-Mest eveneens is onderzocht (dit document was niet door de aanvrager bijgevoegd), wordt gezegd dat volgens de producent van AgriMest de anaërobe fermentatie wordt bevorderd door meer energie beschikbaar te stellen.

Tenslotte is een beschrijving beschikbaar van een aan de leverancier verleend patent ${ }^{4}$ (dit document was niet door de aanvrager bijgevoegd) waarin gewag gemaakt van het werkingsresultaat in de vorm van het verminderen van ammoniak- en methaanemissie door toevoeging van gespecificeerde microorganismen aan mest, maar het werkingsprincipe zelf niet nader toegelicht wordt.

\section{Bespreking werkingsprincipe}

Het werkingsprincipe staat beschreven in 5 bronnen. De derde, vierde en vijfde bron wijken af van de eerste twee doordat deze aangeven dat AgriMestMix / Agri-Mest de anaerobe fermentatie zou ondersteunen, terwijl de eerste twee bronnen aangeven dat het anaerobe proces juist wordt afgeremd. In de bespreking hier wordt uitgegaan van de meest recente opgave van het werkingsprincipe zoals opgegeven in het begeleidend schrijven bij de aanvraag (zie de eerste 4

\footnotetext{
${ }^{2}$ Vliet, P. C. J. van, J. Bloem, R. G. M. de Goede (2006). Microbial diversity, nitrogen loss and grass production after addition of Effective Micro-organisms (EM) to slurry manure. Applied Soil Ecology 32, 188-198. In Bijlage 4.3 is een samenvatting van dit artikel opgenomen.

${ }^{3}$ Stelt, B. van der, E.J.M. Temminghoff, P.C.J. Van Vliet, W.H. Van Riemsdijk (2007). Volatilization of ammonia from manure as affected by manure additives, temperature and mixing, Bioresource Technology 98(18), 3449-3455. In Bijlage 4.4 is een samenvatting van dit artikel opgenomen.

${ }^{4}$ Patent WO 2014/104883 A1. In Bijlage 4.5 is dit patent opgenomen.
} 
pagina's van Bijlage 4.1). Deze beschrijving komt grotendeels overeen met de beschrijving in het rapport van Blauw (2013).

Het werkingsprincipe is gebaseerd op de gedachte dat de anaerobe fermentatie en verbonden gasproductie wordt afgeremd waardoor (meer) stikstof in de mest zou blijven. De hier mogelijk achterliggende gedachte is dat de emissie is gebaseerd op minerale stikstof uit afgebroken organische stof dat als ammoniakgas emitteert. De ammoniakemissie uit stallen is echter volgens de wetenschappelijke literatuur (zie bijv. Aarnink en Elzing, $1998^{5}$ ) hoofdzakelijk afkomstig van ureum dat via de urine is uitgescheiden en in korte tijd (1-2 uur) wordt omgezet naar ammonium (minerale stikstof). De op deze wijze gevormde ammonium emitteert zowel van de stalvloer als vanaf het oppervlak van de mestopslag onder de stalvloer. Slechts een zeer beperkt deel $(<5 \%)$ van de ammoniakemissie uit de stal ontstaat uit minerale $\mathrm{N}$ dat vrij is gekomen uit afgebroken organische stof in de drijfmest (Bruggen et al., 20136; Velthof et al., 20097). Het remmen van anaerobe fermentatie kan op deze wijze niet of nauwelijks effect hebben op de ammoniakemissie.

Volgens de beschrijving neemt door toevoeging van het middel het drogestofgehalte van de mest en het organisch stofgehalte af. Blijkbaar verdwijnen, met uitzondering van stikstof, de overige drogestof-bestanddelen uit de mest. Hoe tegelijkertijd gasvorming wordt afgeremd en het gehalte aan drogestof kan afnemen wordt niet uitgelegd. Afname van drogestofgehalte in een biologisch proces zal normaliter plaatsvinden door gasvormige emissie van omgezette componenten, waarbij het hoofdzakelijk gaat om vorming van gassen zoals $\mathrm{CO}_{2}, \mathrm{CH}_{4}$ en $\mathrm{NH}_{3}$. Een groot deel van de anorganische fractie in de drogestof, bijv. $\mathrm{P}_{2} \mathrm{O}_{5}$, zal niet kunnen emitteren. In een gesloten massabalans zal een afname van drogestof in de vloeibare mest dus altijd samen moeten gaan met gasvorming. Het beschreven werkingsprincipe bevat hiermee redeneringen die strijdig met elkaar zijn.

In de beschrijving wordt gesproken over het opstarten van een aeroob proces in de mest. Omdat de mest niet wordt belucht en omdat minerale zuurstof via het toevoegmiddel ( $15 \mathrm{ml} / \mathrm{dag}$ per afdeling) geen noemenswaardige bijdrage kan leveren is het niet aannemelijk dat proces zonder een extra zuurstofbron op gang kan komen.

De aanvrager geeft aan dat de vrijgekomen stikstof na organische afbraak zich bindt aan 'de kali en de zwavel in de mest, en vormt daardoor een ammoniumnitraat'. Vrijgekomen stikstof zal in de mest voorkomen in de vorm van opgelost ammoniak en ammonium, waarbij de $\mathrm{pH}$ de ligging van dit evenwicht bepaalt en daarmee de vervluchtiging van ammoniak. Een vastlegging van stikstof welke niet vervluchtigt zou een omzetting naar nitraat kunnen zijn via een nitrificatie-proces. Een dergelijk proces kan slechts een significante betekenis hebben indien er voldoende zuurstof beschikbaar is; hiervoor zou een substantiële beluchting noodzakelijk zijn. In het geschetste procedé is hier echter geen sprake van.

\subsection{Wetenschappelijk onderzoek en metingen}

\section{Algemeen}

Onder de door leverancier aangedragen informatie (zie Bijlage 4.1) bevindt zich de volgende onderzoeksinformatie:

1) Rapport van Buro Blauw (2013), vergelijkend emissie-onderzoek op twee varkensbedrijven:

"Onderzoek ammoniakemissiereductie door installatie van mestbewerking. Case-control metingen bij 2 bedrijven".

\footnotetext{
${ }^{5}$ Aarnink, A. J. A., A. Elzing (1998). Dynamic model for ammonia volatilization in housing with partially slatted floors, for fattening pigs. Livestock Production Science, 53, 153-169.

${ }^{6}$ Bruggen, C.van, P. Bikker, C.M. Groenestein, B.J. de Haan, M.W. Hoogeveen, J.F.M. Huijsmans, S.M. van der Sluis, G.L. Velthof (2013). Ammoniakemissie uit dierlijke mest en kunstmest in 2011 : berekeningen met het Nationaal emissiemodel voor Ammoniak (NEMA). WOt-werkdocument 330. Wettelijke Onderzoekstaken Natuur \& Milieu, Wageningen.

${ }^{7}$ Velthof, G.L., C. van Bruggen, C.M. Groenestein, B.J. de Haan, M. W. Hoogeveen, J.F.M. Huijsmans, 2009: Methodiek voor berekening van ammoniakemissie uit de landbouw in Nederland. WOt-rapport 70. Wettelijke Onderzoekstaken Natuur en Milieu, Wageningen, maart 2009.
} 
2) Rapport van Hall instituut (2005), potten- en bemestingsproef uitgevoerd door van Hall: "Onderzoek naar de invloed van Agri-Mest op mest en gras".

3) Rapport van Hall Larenstein (2007), potten- en bemestingsproef uitgevoerd door van Hall Larenstein: "Haalbaarheidsonderzoek verbeterde vergisting door Rinagro producten".

4) Vakbladartikel V-Focus (2006), potten- en bemestingsproef uitgevoerd door Wageningen UR: "Effectieve Micro-organismen verbeteren kwaliteit runderdrijfmest niet". Dit onderzoek is tevens gepubliceerd in een wetenschappelijk tijdschrift door Vliet et al., zoals beschreven in de volgende bron.

5) Wetenschappelijk artikel: Vliet et al. (2006): Microbial diversity, nitrogen loss and grass production after addition of Effective Micro-organisms (EM) to slurry manure (tevens is in Bijlage 4.3 een samenvatting van dit artikel opgenomen)

Niet aangedragen door de leverancier maar wel mee beschouwd in deze beoordeling, omdat het een studie betreft naar hetzelfde product als genoemd in het artikel van Vliet et al., is de reeds eerder genoemde bron:

6) Wetenschappelijk artikel: Stelt et al. (2007): "Volatilization of ammonia from manure as affected by manure additives, temperature and mixing" (in Bijlage 4.4 is een samenvatting van dit artikel opgenomen).

De beschikbare octrooi-beschrijving (zie Bijlage 4.5) verwijst voor ondersteuning van de claims naar het rapport van Buro Blauw en bevat naast een specificatie van het DNA-profiel van in het product voorkomende micro-organismen geen andere onderzoekinformatie die de werking van het product verklaart of ondersteunt.

\section{1: Rapport Buro Blauw}

Buro Blauw is een in Wageningen gevestigd meetbureau dat luchtkwaliteitsmetingen in opdracht uitvoert. Het aangeleverde meetrapport wordt aangeduid als versie 4, en is gedateerd op 27 maart $2013^{8}$. In de eindverantwoording wordt aangegeven dat deze versie alle voorgaande vervangt. Behalve dat het complete rapport is opgenomen in Bijlage 4.1, is de samenvatting van het rapport in Bijlage 4.2 opgenomen. Het rapport bevat een verslag van emissiemetingen op twee varkensbedrijven volgens het case-control principe zoals dat is beschreven in het VERA-meetprotocol (VERA, 2011 ${ }^{9}$ ) en het Nederlandse meetprotocol voor ammoniakemissiefactoren (Ogink et al., $2013^{10}$ ).

De volgende onderdelen van het betreffende meetrapport zullen hier worden besproken: de uitvoering van de case-control opzet, de interpretatie van de resultaten en de daaraan verbonden conclusies.

\section{Uitvoering van de case-control meting}

De meetopzet is gebaseerd op het control-case principe met meerdere over het jaar verspreide vergelijkende metingen. In dit principe is de gelijkheid van afdelingen voor controle en proefbehandeling essentieel voor het verkrijgen van een zuiver behandelingseffect. In de gerapporteerde uitvoering van de meetopzet bleek het volgende:

a) Op beide bedrijven waren de controle-afdelingen tussen andere afdelingen gesitueerd en de proefafdelingen aan de buitenzijde van de stal. Klimaattechnisch leidt dit in de praktijk tot verschillen door het grotere buitenoppervlak van de buitenafdeling. De ventilatieregelingen zijn afgestemd op het voldoende afvoeren van warmte om binnen de temperatuurcomfortzone te blijven. Buitenafdelingen zullen hierdoor lagere ventilatiedebieten hebben. De gerapporteerde gegevens laten een gemiddeld hoger debiet zien voor de controle-afdelingen (gemiddeld $17-27 \%$ hoger). Hogere debieten kunnen aanleiding geven tot hogere luchtsnelheden over emitterende oppervlaktes en daarmee tot hogere emissies. Dit betekent dat het waargenomen case-control verschil deels of volledig zou kunnen worden toegeschreven aan een hoger staldebiet.

\footnotetext{
${ }^{8}$ Het Blauw-rapport was oorspronkelijk niet openbaar maar door publicatie van voorliggend beoordelingsrapport (waarin het is opgenomen in Bijlage 4.1) is het alsnog openbaar gemaakt.

${ }^{9}$ VERA (2011). Test Protocol for Livestock Housing and Management Systems, version 2. Zie VERA-website:

http://www.veracert.eu/en/technology-manufacturers/test-protocols.

${ }^{10}$ Ogink, N.W.M., J. Mosquera Losada, J.M.G. Hol (2013). Protocol voor meting van ammoniakemissie uit huisvestingssystemen in de veehouderij 2013. Rapport 726. Wageningen UR Livestock Reseach, Lelystad.
} 
b) Het gehalte drogestof (ds) van de mest op bedrijf 1 bleek in de proefafdeling vanaf het begin van de metingen structureel lager te zijn dan in de controleafdeling (94 versus $121 \mathrm{~g} \mathrm{ds} / \mathrm{kg}$ mest). Hetzelfde geldt voor het ammonium- $\mathrm{N}$ gehalte in de mest $(4,4$ versus $5,1 \mathrm{~g} \mathrm{NH} 4-\mathrm{N} / \mathrm{kg}$ mest). Op bedrijf 2 waren deze parameters op een gelijk niveau. Dit kan een belangrijke verklaring zijn voor het verschil in ammoniakemissie wat gemeten is tussen de beide afdelingen op bedrijf 1 . Volgens het rapport weerspiegelt het verschil in ds-gehalte op bedrijf 1 het effect van het additief (afbraak van drogestof). Om redenen die hierna worden toegelicht is het echter onwaarschijnlijk dat dit aan het behandelingseffect kan worden toegeschreven, en moet het verschil toegeschreven worden aan een andere managementfactor.

Allereerst is het opmerkelijk dat als de behandeling daadwerkelijk het ds-gehalte verlaagt bedrijf 1 wel $(9,4$ tegen $12,1 \%$ ds) en bedrijf 2 geen (beide $13,2 \%$ ds) verschil vertoont tussen proef- en referentieafdeling.

Volgens het rapport wordt het in vergelijking met bedrijf 1 hogere ds-gehalte van de mest op bedrijf 2 veroorzaakt door de hygroscopische werking van de nieuwe kelderopslag. Om een toename in ds-gehalte van bv. 9,5 naar $12,5 \%$ te realiseren moet echter ca. een kwart van de hoeveelheid water in de mest in de muren worden opgenomen, hetgeen bijzonder onwaarschijnlijk is. (De proportie $p$ van het water in de mest dat in dit geval in de muren van de mestkelder zou zijn opgenomen kan berekend worden uit de vergelijking: $0.125=$ $0.095 /[0.095+0.905 \times(1-p)]$; oplossing van deze vergelijking geeft $p=0.265)$. Tevens verklaart een eventueel hygroscopisch effect niet waarom het verwachte behandelingseffect op de mest achterwege blijft.

De gesuggereerde afbraak van drogestof op bedrijf 1 als resultaat van het additief is eveneens zeer onwaarschijnlijk. In Tabel 4.2 van het rapport is te zien dat het ruwe asgehalte (maat voor anorganische bestanddelen) en de mineralen $\mathrm{P}, \mathrm{K}$ en magnesium, allen stoffen die niet kunnen kunnen vervluchtigen, in de behandelde afdeling van bedrijf 1 gelijkmatig met het drogestof-gehalte afnemen. De fractie ruwe as in de drogestof op bedrijf 1 is nagenoeg constant, respectievelijk 24,5 en $26 \%$ in proef- en referentieafdeling. Bij een gasvormige afbraak van de organische stof en een gelijkblijvende anorganische component zou dit gehalte echter moeten oplopen naar ca. $45 \%$. De cijfers laten veeleer een algeheel verdunningseffect zien. De conclusie is daarom dat het verschil niet zozeer verklaard kan worden door een afbraakeffect als gevolg van het toedieningsmiddel, maar eerder dat een andere managementfactor, bijv. drinkwaterinrichting, hieraan ten grondslag ligt.

\section{Interpretatie van de resultaten en conclusies}

In het rapport wordt de gevonden gemiddelde ammoniakreductie van 26\% uitsluitend toegeschreven aan de behandeling met AgriMestMix. Zoals hiervoor beschreven zitten er echter belangrijke manco's in de case-control opzet van deze meting. $\mathrm{Er}$ is op beide bedrijven sprake van een verstrengeling van afdelingseffecten (verschillen in ventilatieniveau en mestsamenstelling) en potentiële behandelingseffecten. De conclusie in deze beoordeling is dat geen uitspraken over het eventuele effect van het toegediende mestadditief mogelijk zijn door verstorende emissiereducerende factoren in de control-case opzet.

Het geclaimde werkingsmechanisme in de vorm van een afbraak van organische stof en drogestofverlaging in de mest werd niet ondersteund door de mestsamenstelling op het tweede bedrijf. Het verschil in droge stof gehalte van de mest tussen profafdeling en referentieafdeling op het eerste bedrijf weerspiegelt eerder een algeheel verdunningseffect dan een effect dat kan duiden op een hogere afbraak van organische stof.

\section{2 en 3: Potten- en bemestingsproeven}

In deze proeven is vergelijkend onderzoek uitgevoerd naar het effect van AgriMestMix op de mestsamenstelling onder laboratoriumcondities en zijn bemestingsproeven uitgevoerd. In geen van deze onderzoeken is sprake van het meten van ammoniakemissie. 
Van Hall instituut (2005):

In dit onderzoek werd het effect van AgriMest onderzocht op labschaal en via proefveldjes op praktijkschaal. De proef op labschaal bevatte geen herhalingen en laat daarmee geen conclusies toe. De toepassing op proefveldjes bevatte een beperkt aantal herhalingen (drie met en drie zonder behandeling). In de rapportage is geen statistische uitwerking van de resultaten opgenomen. T.a.v. de bemestingsproef wordt opgemerkt: 'Geconcludeerd kan worden dat mest behandeld met Agri-Mest stikstof bevat, welke sneller beschikbaar komt voor de plant. De mest is beter mixbaar doordat de drogestof afneemt'.

Van Hall Larenstein (2007):

In dit onderzoek werd het effect van AgriMest op de biogasproductie van mest onder mesofiele omstandigheden onderzocht. Het onderzoek was gebaseerd op 3 batches mest waarvan één onbehandeld, één met AgriMest en één met Agrimest + micro-organismen. De biogasproductie (aantal liters) werd vervolgens in duplo per batch gemeten; het ammoniakgehalte van het biogas werd niet gemeten. De mestsamenstelling werd geanalyseerd voor en na de experimenten. Door het ontbreken van herhalingen op batch-niveau en de ongelijke mestsamenstelling bij aanvang van de proef zijn echter geen goed onderbouwde uitspraken mogelijk wat betreft de invloed van de gebruikte toevoegmiddelen op het vergistingsproces of de mestsamenstelling.

Uit deze 2 onderzoeken komt geen coherent beeld naar voren met betrekking tot de mogelijke werking van AgriMest of AgriMestmix richting ammoniakemissie.

4 en 5: Peer-reviewed artikel Vliet et al. (2006), eveneens gepubliceerd in vakbladartikel In dit onderzoek werd het effect van zogenoemde Effectieve Micro-organismen in samenhang met Agrimest onderzocht door de mestsamenstelling in potten met mest in de tijd te volgen. Daarnaast werd een pottenproef uitgevoerd om de effecten op grasopbrengst te onderzoeken. Het onderzoek bevatte geen metingen van de ammoniakemissie uit de mest. Eén van de resultaten in dit labonderzoek was dat het minerale $\mathrm{N}$ gehalte $\left(\mathrm{NH}_{4}-\mathrm{N}\right.$ of TAN) in met Agrimest behandelde mest na 56 dagen hoger was dan in onbehandelde mest (significant verschil). In de tekst wordt hierover opgemerkt dat de ammoniakvervluchtiging in deze mest misschien lager was. Dit zou volgens de auteurs veroorzaakt kunnen worden doordat een (deel) van de ammonium gebonden wordt aan de (klei)mineralen. In de pottenproef met grasopbrengst bleek dat de $\mathrm{N}$-opname in gras bij de Agrimestbehandeling lager uitviel. Voor het overige werden geen effecten gevonden.

\section{6: Peer-reviewed artikel Van der Stelt et al. (2007)}

In dit onderzoek zijn de effecten van 3 mestadditieven, waaronder AgriMest, op de mestsamenstelling (rundermest) onderzocht in een laboratoriumproef met mestpotten. De factoriële proef bestond naast de 3 behandelingen en een onbehandelde referentie, uit 3 temperatuurbehandelingen en een mix- en een niet-mix behandeling $(4 \times 3 \times 2)$. In aanvulling op de mestsamenstelling werd tevens de $\mathrm{NH}_{3}$-emissie uit deze potten gemeten. De werking van AgriMest is volgens opgave van de producent in dit artikel gebaseerd op bevordering van de anaerobe afbraak door de hoeveelheid beschikbare energie voor deze afbraak te vergroten. De conclusie van het artikel is dat er geen aantoonbare effecten van de additieven op de mestsamenstelling, waaronder N-mineralisatie, zijn. Het N-mineralisatie effect gerapporteerd door Vliet et al. (2006) wordt niet bevestigd. Van de 18 behandelingscombinaties is er 1 combinatie die een significant lagere $\mathrm{NH}_{3}$-emissie geeft t.o.v. de referentie $(p<0,05)$. Het betreft hier een effect van AgriMest bij $4{ }^{\circ} \mathrm{C}$ en niet-mixen. Voor de andere temperatuurniveaus ( 20 en $35^{\circ} \mathrm{C}$ ) zijn geen effecten van AgriMest aangetoond. Gezien de inconsistentie van effecten en het aantal behandelingscombinaties kan hier sprake zijn van een statistische toevalstreffer. Nader onderzoek zou nodig zijn om dit effect te bevestigen en een eventueel verklarend mechanisme te vinden. 


\subsection{Overige aspecten}

Naast het mogelijke effect op de stikstofhouding en ammoniakvervluchtiging uit de stal, zoals besproken in voorgaande paragraaf, stelt de aanvrager dat de emissie van methaan en lachgas zal afnemen. In het rapport van Buro Blauw wordt een reductie van de methaanemissie gerapporteerd. Dit emissie-onderzoek in twee varkensstallen laat echter geen uitspraken toe over het eventuele effect van het toegediende AgriMestMix omdat in de control-case opzet behandelings- en afdelingseffecten waren verstrengeld (zie paragraaf 3.3).

Op de vraag of de aanvrager ideeën heeft met betrekking tot de wijze waarop toepassing van de additieven kan worden gecontroleerd of gehandhaafd, geeft de aanvrager aan dat het aankopen van de additieven geen garantie is voor het toepassen ervan. De suggestie wordt geopperd om het toedienen van het middel in handen te geven van een gecertificeerde instantie, vergelijkbaar met een ongediertebestrijder in de veevoedersector.

\subsection{Discussie en conclusie}

In de voorgaande paragrafen is een analyse gemaakt van het mogelijke effect van de toepassing van het AgriMestMix systeem, waarbij additieven worden toegevoegd aan de mest. De analyse is gebaseerd op de door de aanvrager aangeleverde informatie en overige beschikbare (wetenschappelijke) literatuur.

Het beschreven werkingsmechanisme geeft geen plausibele verklaring voor het terugdringen van ammoniakemissie. De beschrijving van dit mechanisme bevat onderdelen die strijdig met elkaar zijn. Op geen enkele manier wordt duidelijk gemaakt via welke microbiële omzettingsstappen, bijbehorende omzettingsproducten en chemische evenwichten het beoogde effect zou kunnen worden verklaard. Het beschreven werkingsmechanisme wordt niet ondersteund door effecten op mestsamenstelling in het emissie-onderzoek dat werd uitgevoerd in twee varkensstallen (Blauw, 2013). Dit emissieonderzoek in twee varkensstallen (Blauw, 2013) laat geen uitspraken toe over het eventuele effect van het toegediende AgriMestMix omdat in de control-case opzet behandelings- en afdelingseffecten waren verstrengeld. Verder wordt het door Vliet et al. (2006) waargenomen effect op N-mineralisatie in de mest niet bevestigd in het onderzoek van Stelt et al. (2007).

Op basis hiervan wordt geconcludeerd dat er onvoldoende onderbouwing is om te concluderen dat toepassing van het AgriMestMix systeem een emissiereductie van ammoniak uit de stal tot gevolg heeft. 


\section{Bijlagen}

4.1 Brief van leverancier / aanvrager aan WLR met bijlagen en documenten (89 pagina's) 
Piaam 01-10-2013

Onderwerp: PAS maatregelen

Ons kenmerk: 13/R00477/MELS/nk

Bijlagen: Onderzoek ammoniakreductie door installatie van mestbewerking Buro Blauw

: Onderzoek naar de invloed van Agri-Mest op mest en gras

: Haalbaarheidsonderzoek verbeterde vergisting door Rinagro producten

: Microbial diversity, nitrogen loss and grass production after addition of effective Microorganismen (EM) to slurry manure

: Effectieve Micro-organismen verbeteren kwaliteit runderdrijfmest niet.

: Octrooinummer 2009019

: Versgras analyses van onbehandelde mest bemest gras versus behandeld mest.

: Foto materiaal van demo velden DLV plant en de veen koloniën.

:Verkenning vermindering uitstoot broeikasgassen uit opslag vaste mest.

: Lopende proeven demo velden DLV Plant zomer 2013 met E.H.Emmens 06-53175863

: Lopende proef demo veld veenkoloniën

Geachte heren,

Naar aanleiding van uw verzoek, tot het beantwoorden van uw vragen voor de aanpak van P.A.S., zal ik proberen de informatie aan te leveren over de werking van onze maatregel mestbewerking met AgriMestMix en de vragen te beantwoorden.

Het ontwikkelen van een product voor in de mest is ontstaan, omdat de mest niet goed benut werd tijdens de groeiperiode van de gewassen.

Voor drijfmest geldt dat bij de aanwending van de mest in februari er van het minerale gedeelte van de mest een gedeelte uitspoelt of verluchtigt voor het benutten van de eerste snede, er blijft van de $2,2 \mathrm{~kg}$ maar $1 \mathrm{~kg}$ over, het organische deel van de mest komt na mineralisatie pas na augustus vrij. Hiervan kan nog 1 maaisnede van benut worden; de rest spoelt uit in de winter, door nitraat uitspoeling.

Daardoor moet het jaar daarop, voor de eerste gras snede weer volop bemest worden.

Door na te gaan denken over een mogelijkheid om tijdens de winter opslagtijd van drijfmest, deze tijd te benutten om de mest te bewerken of te laten rijpen.

Dit geldt ook voor het composteren of het omzetten van de vaste mest.

Het verbaasde mij dat melkveehouders duizenden euro's uitgeven om hun voorraad kuilgras te behandelen om te voorkomen dat deze gaat broeien of warm wordt, is dit het geval dan verliest het kuilgras zijn voedingswaarde en de energie.

Is deze veehouder in het bezit van vaste mest, dan wordt hem geadviseerd om deze regelmatig om te zetten, hierdoor word de mest warm en gaat broeien zo verteerd het organische materiaal deze moet afbreken zodat het beter is voor het land/grond bodem.

Door het composteren op deze manier gaat veel waardevolle energie verloren en gaan broeikas gassen de lucht in, stikstof energie in vorm van methaan belangrijke voedingselementen voor de bodem. Grote tegenstrijdigheden in mijn beleving. Niemand kon mij uitleggen waarom. 
Vraag 1

AgriMestMix veranderd de biochemische processen in de mest, het natuurlijk mineralenmengsel heeft een sterke remming op de methanogene fase (gasproductie) door het stoppen van het anaerobe proces in de mest en het opstarten van een aerobe proces vindt er een reductie van broeikas gassen plaats zoals ammoniak, methaan en lachgas.( zie rapporten )

Door de reductie van zowel ammoniak, methaan en lachgas word het verdringing principe bevestigt. Ook als er in de mest een afwenteling plaats vind naar een andere gasvorm bv van ammoniak naar methaan of lachgas dan vind er met de AgriMestMix maatregel een reductie plaats (zie rapport blauw)

Omdat het om een verdringing principe gaat, werkt de maatregel in drijfmest van alle diersoorten en vaste mest van alle diersoorten en ander te composteren materialen.

Als er AgriMestMix aan de drijfmest word toegevoegd, vind door de processen een afbraak van organisch materiaal plaats, de stikstof die hier bij vrij komt bindt zich net als de andere minerale stikstof aan de kali en de zwavel in de mest, en vormt daardoor een ammoniumnitraat.

De behandelde mest komt hierdoor sneller beschikbaar voor planten en word beter benut tijdens het groeiseizoen.

Door de aerobe omstandigheden in de mest worden er ook micro-organismen in de mest gekweekt die ook in de bodem passen zoals de micoritza schimmel welke zeer belangrijk is voor de wortelgroei. Meer wortelvorming zorgt voor een hoger organische stof in de bodem, en een hoger organische stof in de bodem geeft weer een hogere stikstof levering vanuit de bodem en hierdoor een besparing op kunstmest stoffen. (zie foto's demoveld DLV plant.)

In de versgras analyses zorgt deze ontwikkeling in de bodem voor verrassende eiwit vormen in het gras, die makkelijker opneembaar zijn voor de koe.

Dit geeft een efficiëntere $\mathrm{N}$ benutting via het ruwvoer ( zie vers gras analyse ).

Ook methaan uitstoot op koe niveau zou lager kunnen zijn, dit vraagt om meer onderzoek.

De maatregel zou in dit geval dus altijd in aanmerking moeten komen voor de hoogste emissiereductie met de laagste energieverbruik tijdens het gebruik, daar komt nog bij dat met het uitrijden van de behandelde mest er ook een lagere uitstoot van broeikas gassen is (zie test vaste mest ).

Daarmee is de maatregel geen end-of-pipe maatregel maar een procesgeintergreerd.

Een procesgeintergeerd systeem heeft naast boven genoemde resultaten nog als voordeel dat het goed is voor dierwelzijn en menswelzijn. 
Vraag 2:

Het werkingsprincipe is gebaseerd op het verdringingsprincipe. Het verdringt fysisch het anaerobe proces. Dit wordt bevestigd door de meet resultaten die laten chemisch zien dat er een reductie optreedt van zowel ammoniak, methaan en lachgas. (zie haalbaarheidsonderzoek Bureau Blauw en het Haalbaarheidsonderzoek verbeterde vergisting door Rinagro producten)

Uitstoot van broeikas gassen zoals ammoniak,methaan en lachgas is een puur anaerobe bacteriee proces, relevante reactievergelijkingen zijn nauwelijks te maken, omdat door de wisselende samenstellingen van de verschillende mestsoorten ook al afwentelingen plaats vinden naar andere broeikas gassen vanuit de ammoniak.

Petra van Vliet heeft aangetoond in haar onderzoek van 2005 dat er met AgriMest significant meer stikstof in de mest blijft dan zonder toediening. In dit zelfde jaar is aangetoond met een afstudeeropdracht dat deze meer stikstof hogere eiwitwaarden in gras laat zien. Deze 2 onderzoeken hebben geleid tot een verder zoeken van mogelijkheden. In genoemde onderzoeken werd naast een vloeibaar AgriMestMix ook een mineraal poeder, genaamd AgriMest Mineraal, gebruikt. Na verder onderzoek is gebleken dat de resultaten uit de onderzoeken toe te schrijven waren aan uitsluitend de vloeibare versie van AgriMest. De verdere onderzoeken zijn dan ook uitsluitend met de vloeibare versie uitgevoerd. De dosering van de vloeibare versie is verhoogd en er zijn micro-organismen aan toegevoegd. Dit heeft de werking verbeterd; tegelijkertijd geeft dit aan dat de resultaten van het onderzoek van Petra van Vliet en het afstudeerproject maar een minimale hoeveelheid aan werkzaam product is gebruikt. Het gaat om ongeveer een kwart van de dosering nu. Zie ook andere onderzoeken.

Vraag 3:

Ja, zie literatuur van bijlagen.

Vraag 4:

Niet van toepassing

Vraag 6:

Ja, zie literatuur van: Onderzoek naar de invloed van Agri-Mest op mest en gras.

: Onderzoek Buro Blauw

: zie vers gras analyses.

: Lopende onderzoek DLV Plant van E.H Emmens

: project veenkoloniën. 


\section{Vraag 7:}

Ja, zie rapport Buro Blauw

\section{Vraag 8:}

De neveneffecten zijn dat bij toepassing van de maatregel naast ammoniak ook de methaan en het lachgas gereduceerd worden. (zie meting Haalbaarheidsonderzoek verbeterde vergisting door Rinagro producten en Buro Blauw). Het kent dus een veel hogere reductie van broeikasgassen. Dit komt ten goede aan de brandveiligheid en de volksgezondheid.

\section{Vraag 9:}

Het kan door automatische toediening geregistreerd worden.(zie octrooi met nummer 2009019), Door vastleggen van hoeveelheid product per $\mathrm{m}^{3}$, en de behandelde mest van een certificaat voorzien, de bewerkte mest krijgt dan de naam for-profit.

De toediening kent financiële voordelen voor gebruiker. De behandelde mest kent een meerwaarde en vertoond bij gras een hoger eiwit en in de akkerbouw een hogere opbrengst, en een betere werking coëfficiënt. Er wordt geld verdiend aan deze mest en de toedienende partij zal er dus alles aan doen om het systeem te laten werken.

Mochten er nog vragen zijn over de antwoorden die gegeven zijn, dijn zijn wij altijd bereid deze te Beantwoorden.

Met vriendelijke groet,

Rinze Joustra

RINAGRO

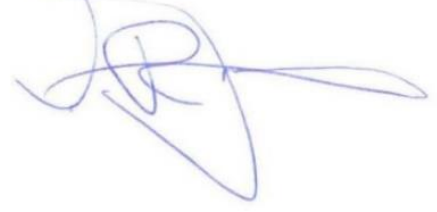




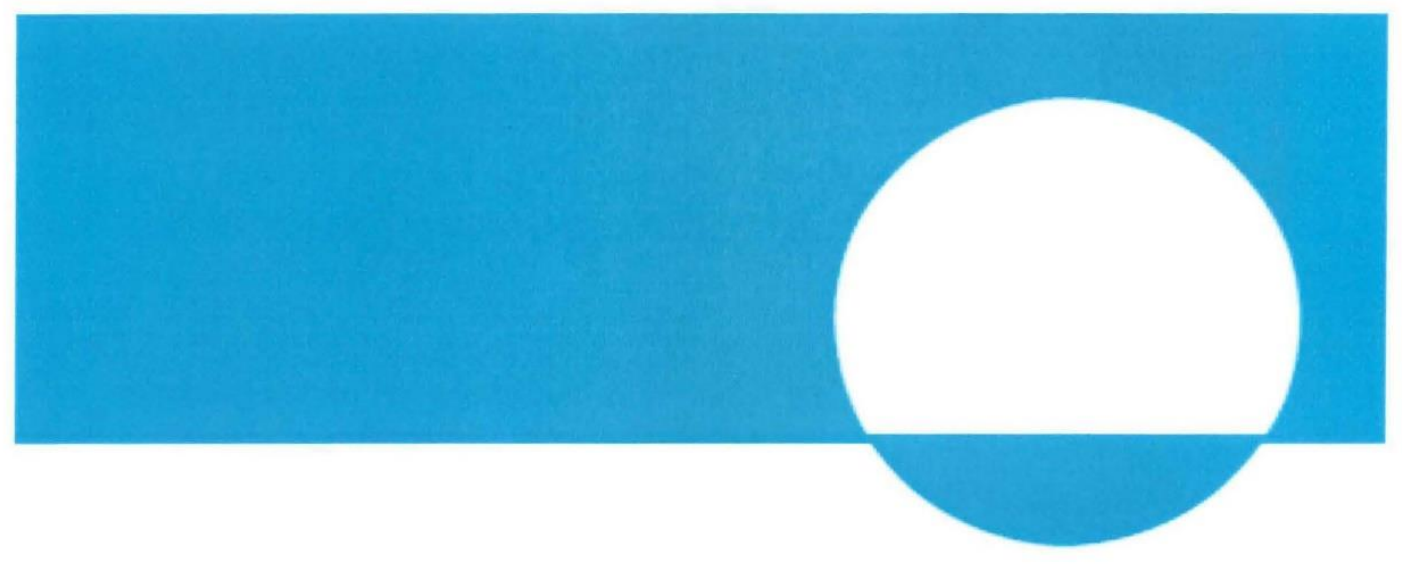

ONDERZOEK AMMONIAKEMISSIEREDUCTIE DOOR INSTALLATIE VAN MESTBEWERKING

Case -control metingen bij 2 bedrijven

Rapportnummer: $\quad$ BL2012.5216.02-V04

27 maart 2013 


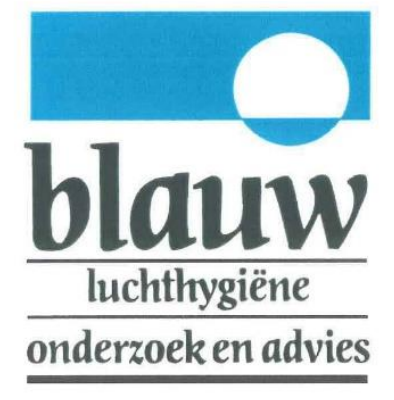

ONDERZOEK AMMONIAKEMISSIEREDUCTIE DOOR INSTALLATIE VAN MESTBEWERKING

Case -control metingen bij 2 bedrijven

Rapportnummer: $\quad$ BL2012.5216.02-V04

27 maart 2013

खUA

IESTING

Nude 54 - 6702 DN Wageningen $\begin{array}{ll}\text { IESTING } & \text { telefoon } 0317466699-\text { fax } 0317426111 \\ \text { RVA L 400 } & \text { email info@buroblauw.nl - internet www.buroblauw.nl }\end{array}$ 


\section{VOORWOORD}

Buro Blauw heeft in opdracht van Rinagro uit Piaam een onderzoek uitgevoerd naar de ammoniakemissies van varkensstallen waarin een mestbewerkingsinstallatie geïnstalleerd is. Bij de uitvoering van het meetprogramma is nauw samengewerkt met de heer Arjen Dijkstra van adviesbureau Dijkstra Agrimarketing.

Arjen Dijkstra heeft de t.b.v. de rapportage benodigde zoötechnische gegevens verzameld. $\mathrm{Hij}$ is ook verantwoordelijk voor de rapportage van de zoötechnische gegevens in hoofdstuk 2 en 3 en heeft de verschillen in de gemeten ammoniak emissiefactoren bij de twee stallen vanuit zoötechnisch oogpunt beoordeeld.

Buro Blauw heeft de ammoniakemissiemetingen uitgevoerd en gerapporteerd en is eindverantwoordelijke voor de gehele rapportage

Wageningen, 27 maart 2013

Frans de Bree

Directeur Buro Blauw

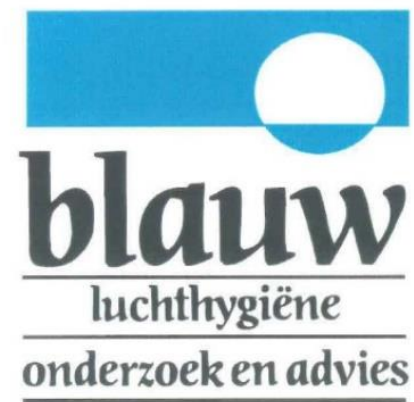




\section{SAMENVATTING}

Buro Blauw heeft in opdracht van Rinagro uit Piaam een meetprogramma uitgevoerd voor het vaststellen van de ammoniakemissiereductie voor stalsystemen voor vleesvarkens met een installatie voor mestbewerking.

De doelstelling van de metingen is de ammoniakemissie van deze installatie vast te stellen die opgenomen kan worden in de Regeling Ammoniak Veehouderij (RAV). Hiertoe is door Buro Blauw een meetplan opgesteld, welke positief geadviseerd is door de Technische Advies Commissie RAV. Het meetplan bestond uit het uitvoeren van ammoniakemissiemetingen gedurende $6 * 24$ uur bij 2 stallen met 2 identieke lokalen. Dit is de zogenaamde case - control methode. De metingen zijn uitgevoerd bij de volgende veehouderij bedrijven:

1. Van de Beek - Putten

2. Van de Brandhof - Ede -

De diercategorie in de lokalen waar de metingen zijn uitgevoerd bij Van de Beek in Putten valt onder Rav code D.3.2.1.2. De door Buro Blauw gemeten emissiefactor van de referentieafdeling van Van de Beek in Putten bedraagt 6,3. $\mathrm{Kg} \mathrm{NH}_{3}$ per dier per jaar (incl. $10 \%$ leegstand). Dit is hoger dan de emissiefactor die is opgenomen in bijlage 1 van de Rav (4,0 Kg NH 3 per dier per jaar). Dit kan verklaard worden door het feit dat de varkens al zwaarder zijn als ze het lokaal in komen.

De diercategorie in de lokalen waar de metingen zijn uitgevoerd bij Van de Brandhof in Ede valt onder Rav code D.3.2.1.1. De door Buro Blauw gemeten emissiefactor van de referentieafdeling van Van de Brandhof in Ede bedraagt 1,8. $\mathrm{Kg} \mathrm{NH}_{3}$ per dier per jaar (incl. $10 \%$ leegstand). Dit is lager dan de emissiefactor die is opgenomen in bijlage 1 van de Rav (3,0 $\mathrm{Kg} \mathrm{NH}_{3}$ per dier per jaar). Dit verschil wordt verklaard door de nieuwheid van de stal.

Het meetprogramma is conform het meetplan uitgevoerd in de periode juli $2011 \mathrm{t} / \mathrm{m}$ maart 2012. De metingen zijn storingsvrij verlopen. Bij de 2 bedrijven zijn metingen uitgevoerd in de zes delen van de groeicyclus van vleesvarkens. Er zijn in totaal 4 metingen in de winter, 4 metingen in de zomer en 4 metingen in het voor- of najaar uitgevoerd. De metingen op de twee locaties zijn voor wat betreft de groeifase redelijk verdeeld over de seizoenen uitgevoerd. Hiermee is voldaan aan de organisatorische vereisten voor de uitvoering van het onderzoek.

Bij beide bedrijven is sprake van een gelijk aantal dieren in de case- en controlafdeling. Ook is sprake van een klein acceptabel verschil in gewicht van de dieren in beide afdelingen. Hierbij is sprake van een geslaagde meetopzet voor de case - control methode.

Uit de metingen is een duidelijk verschil naar voren gekomen in de ammoniakemissiereductie bij de beide bedrijven. Bij Van de Beek in Putten is een gemiddelde reductie gemeten van $35 \%$ en bij Van de Brandhof in Ede van $17 \%$. Hiermee is een gemiddelde ammoniakemissiereductie van $26 \%$ aangetoond. 


\section{blauw}

Het verschil in de gemeten ammoniakemissiereductie bij van de Beek en van de Brandhof kan worden toegeschreven aan de invloed van het nieuwe beton op de mestsamenstelling bij van de Brandhof in Ede. Bovendien is bij van de Brandhof sprake van een lage ammoniak emissiefactor. Hierdoor heeft het verlagen van de putemissie door de installatie van mestbewerking nog slechts een beperkt effect op de totale emissie van de stal.

In het onderzoek zijn diverse factoren die van invloed kunnen zijn op de gemeten ammoniakemissiereductie onderzocht. Dit betreft:

- $\quad$ het verschil in gewicht van de dieren tussen de case en control afdeling;

- het verschil in ventilatiedebiet van de case en control afdeling;

- het verschil in de samenstelling van de mest tussen de case en control afdeling;

- $\quad$ het verdunnen van de mest door de installatie voor bewerking.

Uit de analyse van de meetresultaten blijkt dat de gemeten ammoniakemissiereductie niet toegeschreven kan worden aan bovengenoemde factoren.

Bij van de Beek wordt een methaanemissiereductie gemeten van $16 \%$. Er wordt geen lachgasemissiereductie gemeten. Bij Van de Brandhof wordt in de stal met de installatie voor mestbewerking een 35\% lagere methaanemissie en een $20 \%$ lagere lachgasemissie gemeten ten opzichte van de referentieafdeling. Gemiddeld is er bij beide bedrijven een methaanemissiereductie gemeten van $20 \%$ en een lachgasemissiereductie van $8 \%$.

Uit het onderzoek wordt geconcludeerd dat de gemeten emissiereductie van ammoniak, methaan en lachgas toegeschreven moet worden aan de invloed van de installatie voor mestbewerking. 


\section{INHOUDSOPGAVE}

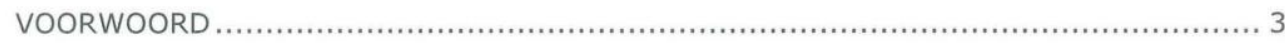

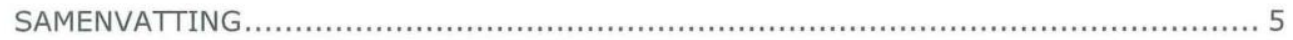

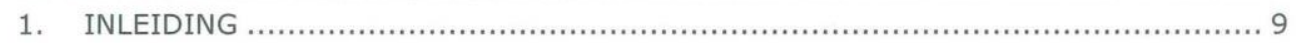

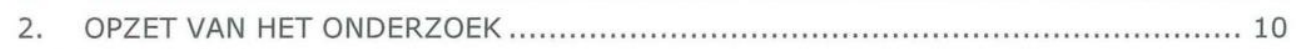

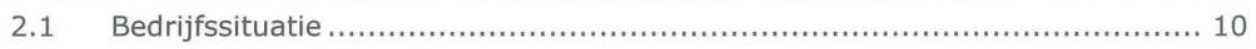

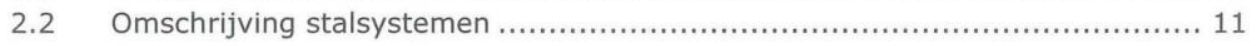

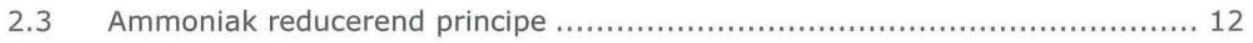

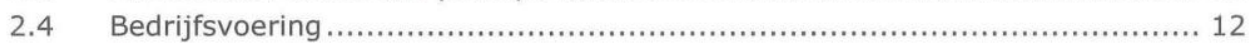

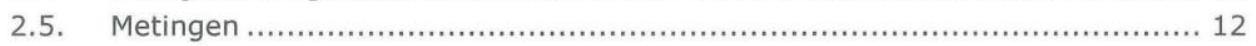

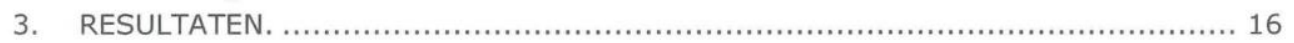

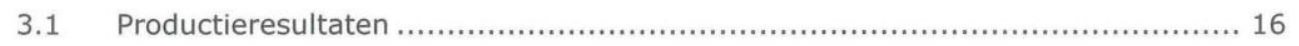

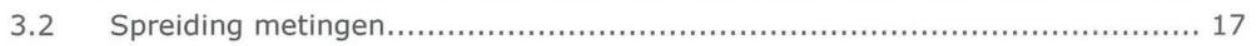

3.3 Resultaten van de ventilatiedebietmetingen ........................................... 18

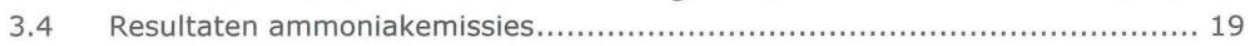

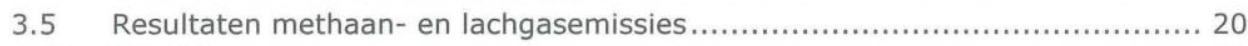

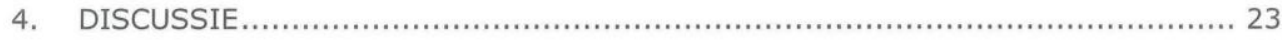

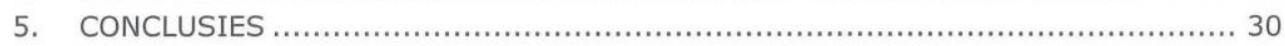

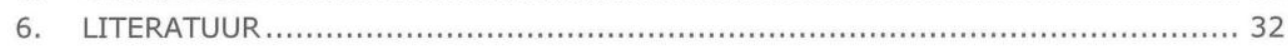

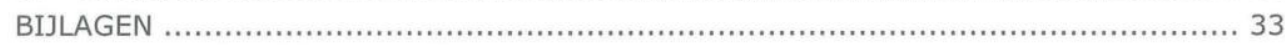

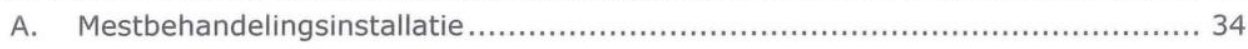

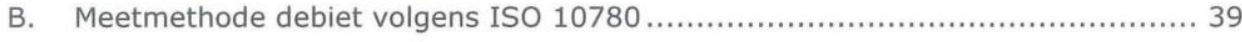

C. Meetmethode ammoniak ................................................................. 40

D.1 Technische gegevens Van de Beek in Putten ..................................... 41

D.2 Technische gegevens Van de Brandhof in Ede ............................... 44

E.1 Gedetailleerde gegevens metingen Van de Beek Putten .......................... 47

E.2 Gedetailleerde meetgegevens Van de Brandhof Ede .............................. 49

F Resultaten ammoniakconcentratiemetingen met een ammoniakmeter ............ 51

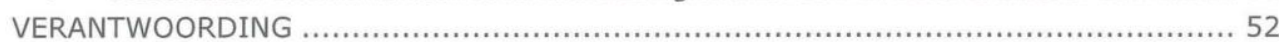


Pagina 8 van 52 


\section{INLEIDING}

Buro Blauw heeft in opdracht van Rinagro uit Piaam een onderzoek uitgevoerd naar de ammoniakemissies uit varkensstallen waarbij de mest in de mestput door de installatie voor mestbewerking wordt voorzien van AgriMestMix. Het betreft varkensstallen met de diercategorie vleesvarkens (D.3.2.1.1 en D.3.2.1.2).

De doelstelling van de metingen is de ammoniakemissiereductie vast te stellen voor de installatie voor mestbewerking zodat de gemeten ammoniakemissiereductie opgenomen kan worden in de Regeling Ammoniak Veehouderij (RAV). Hiertoe is door Buro Blauw een meetplan opgesteld welke positief geadviseerd is door de Technische Advies Commissie RAV (RAV10063). Het meetplan bestond uit het uitvoeren van ammoniak,- lachgas en methaanemissiemetingen volgens de case-controlmethode. Hierbij wordt gedurende 6 * 24 uur de ammoniakemissie gemeten bij 2 stallen met 2 vergelijkbare afdelingen waar bij 1 afdeling de mest is behandeld door de installatie voor mestbewerking (case-afdeling) en bij 1 afdeling niet (controlafdeling). Ook zijn er mestmonsters op de meetdagen genomen. Dit betreft volgende veehouderij bedrijven:

1. Van de Beek - Putten

2. Van de Brandhof - Ede

De metingen zijn verdeeld over de groeicyclus en verdeeld over de seizoen uitgevoerd, waarbij de lente en herfst als vergelijkbare seizoenen zijn beschouwd. De eerste meting is uitgevoerd op 27 juli 2011 en de laatste meting is uitgevoerd op 5 maart 2012.

In dit rapport worden de resultaten van de metingen gerapporteerd. In hoofdstuk 2 wordt de onderzoeksopzet besproken. Hierbij wordt ingegaan op het stalsysteem, het ammoniakreducerend principe van de installatie voor mestbewerking, de bedrijfsvoering in de stallen tijdens de metingen, de meetopzet en de gehanteerde meetmethoden en de dataverwerking.

In hoofdstuk 3 worden de resultaten van het onderzoek gepresenteerd. Hierbij worden de productiegegevens, de zoötechnische gegevens, het klimaat en de ventilatie van de stallen en de resultaten van de ammoniak concentratiemetingen besproken.

In hoofdstuk 4 wordt de gemiddelde ammoniakemissiereductie voor de installatie voor mestbewerking bepaald. Hierbij wordt tevens ingegaan op de gerealiseerde ammoniakreductie van deze installatie en wordt deze verklaard vanuit het opgegeven ammoniak reducerend principe. Ook wordt gekeken naar verschillen tussen de case en control afdeling en de mogelijke invloed van deze verschillen op de gemeten ammoniakreductie door de installatie voor mestbewerking.

In hoofdstuk 5 worden de conclusies van het onderzoek geformuleerd.

In de bijlagen staan gedetailleerde gegevens over de stalsystemen, de landbouwkundige parameters van de stallen tijdens de meetperiode en de resultaten van de metingen. 


\section{OPZET VAN HET ONDERZOEK}

\subsection{Bedrijfssituatie}

De metingen zijn bij 2 bedrijven uitgevoerd, te weten:

- Het varkensbedrijf van de heer J. van de Beek ligt aan de Houtweg 5 in Putten. Op het bedrijf zijn voornamelijk varkens aanwezig. De metingen zijn uitgevoerd aan een stal met 5 lokalen. De metingen zijn uitgevoerd in lokaal 3 (referentie) en lokaal 5 (installatie voor mestbewerking). In bijlage D wordt het stalsysteem van de heer Van de Beek waarin de metingen zijn uitgevoerd uitgebreid omschreven. In figuur 2.1 wordt de ligging van het bedrijf gegeven. De stal is in de figuur met een prikker aangegeven.

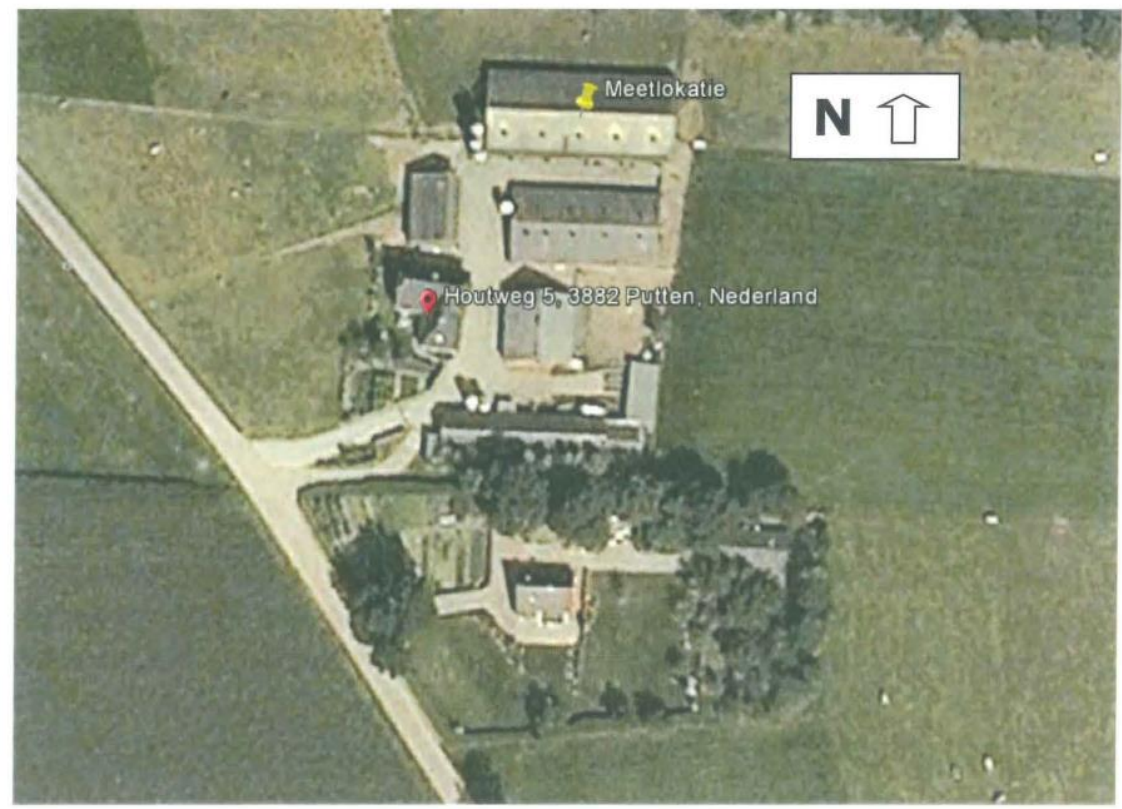

Figuur 2.1 Overzichtfoto van de ligging van het varkensbedrijf J. van de Beek in Putten (foto overgenomen van Google Earth).

Het varkensbedrijf van de heer D. van de Brandhof ligt aan de Peteweg 9 in Ede. Op het bedrijf zijn alleen varkens aanwezig..De metingen zijn uitgevoerd in lokaal 23 (referentie) en lokaal 21 (installatie voor mestbewerking). In bijlage D wordt het stalsysteem van de heer Van de Brandhof waarin de metingen zijn uitgevoerd uitgebreid omschreven. In figuur 2.2 wordt de ligging van het bedrijf gegeven. Op de foto is de stal waar de metingen uitgevoerd zijn nog niet te zien. De locatie waar de stal gebouwd is, is in de figuur aangegeven met een prikker. 


b10WW $\begin{array}{r}\text { Rapportnr. BL2012.5216.02-V04 } \\ 27 \text { maart } 2013 \\ \text { Pagina } 11 \text { van } 52 \\ \end{array}$

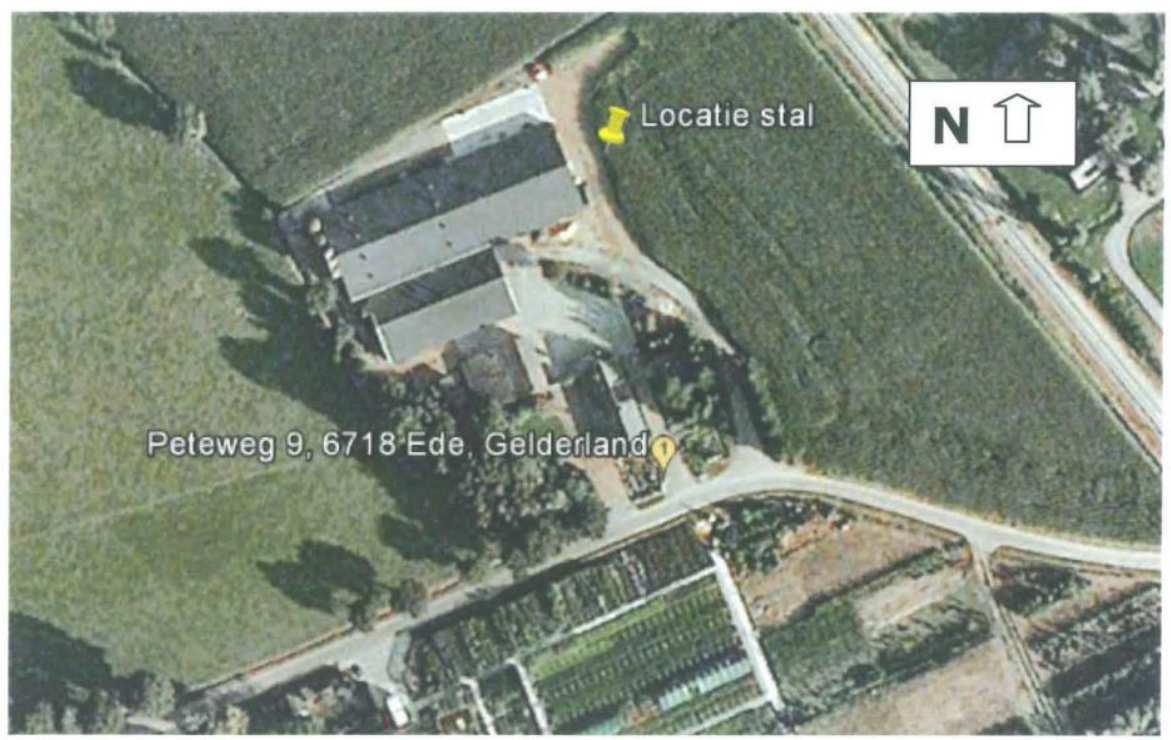

Figuur 2.2 Overzichtfoto van de ligging van het varkensbedrijf $D$. van de Brandhof in Ede (foto overgenomen van Google Earth).

\subsection{Omschrijving stalsystemen}

\subsubsection{SYSTEEMOMSCHRIJVING}

In de volgende paragrafen worden de stalsystemen van de twee bedrijven beschreven. In bijlage $\mathrm{A}$ wordt de werking van de installatie van mestbewerking beschreven.

\subsubsection{STALSYSTEEM J. VAN DE BEEK IN PUTTEN}

De stal heeft een halfroostervoer met een traditionele mestafvoer. Er worden maximaal 400 varkens gehuisvest verdeeld over 5 lokalen met een maximum aantal van 80 varkens per lokaal. Elk lokaal heeft 8 hokken, 4 aan elke kant van de voergang. De drinkwatervoorziening is onbeperkt. Per lokaal is 1 ventilator aanwezig die op temperatuur in de stal geregeld wordt. De aanvoer van verse lucht vindt via de deur plaats.

\subsubsection{STALSYSTEEM D. VAN DE BRANDHOF IN EDE}

De stal heeft een halfroostervloer met een traditionele mestafvoer. Er worden maximaal 576 varkens gehuisvest verdeeld over 6 lokalen met een maximum aantal van 96 varkens per lokaal. Elk lokaal heeft 8 hokken, 4 aan elke kant van de voergang. De drinkwatervoorziening is onbeperkt. Per lokaal is 1 ventilator aanwezig die op temperatuur in de stal geregeld wordt. De aanvoer van verse lucht gebeurt via de vloer. 


\section{blauw \\ Rapportnr. BL2012.5216.02-V04 \\ 27 maart 2013 \\ Pagina 12 van 52}

\subsection{Ammoniak reducerend principe}

De mestbewerkingsinstallatie reduceert de ammoniakuitstoot door dagelijks een hoeveelheid natuurlijk mineralenmengsel te sprayen over de drijfmest. Door dit dagelijks te herhalen verandert het proces in de mest. Hierdoor stopt de gasvorming in de mest en wordt de emissie van onder andere ammoniak gereduceerd. De stikstof blijft in de mest en komt later beschikbaar voor de planten. Het droge stofgehalte van de mest en het organisch stofgehalte nemen door toevoeging van het mineralenmengsel af. Het natuurlijk mineralenmengsel bestaat uit natuurlijke mineralen, minerale zuurstof en een aantal specifieke bacteriën.

De natuurlijke mineralenmengsel heeft een sterke remming op de methanogene fase (gasproductie). Door het stoppen van het anaerobe proces in de mest en het opstarten van een aerobe proces vindt er een reductie plaats van de ammoniakemissie.

\subsection{Bedrijfsvoering}

\subsubsection{ZOÖTECHNIEK}

In de bijlagen D.1 en D. 2 staan gegevens over de bedrijfsvoering van de twee bedrijven van alle productieronden waar in gemeten is.

\subsubsection{VOORWAARDEN}

De meetlocaties moesten aan de volgende voorwaarden voldoen:

- De afdelingen waar gemeten wordt zijn tenminste twee maanden in gebruik;

- De vleesvarkens worden gehouden volgens de geldende welzijnsnormen;

- Het aantal varkens in een hok ligt tussen 10 en 40;

- Drinkwater is onbeperkt beschikbaar

- De groei van de varkens van $25-115 \mathrm{~kg}$ is minimaal $750 \mathrm{~g} / \mathrm{dag}$;

- De uitval is maximaal $5 \%$;

- Het minimum aantal varkens per lokaal is 50 .

Beide meetlocaties voldoen aan al deze eisen.

\subsection{Metingen}

\subsubsection{KWALITEITSBORGING}

De Raad voor Accreditatie heeft Buro Blauw B.V. met ingang van 28 juli 2004 de accreditatie verleend voor de uitvoering van verschillende verrichtingen door de meetdienst conform NEN-EN-ISO/IEC 17025 (nl) (2005), Algemene eisen voor de competentie van beproevings- en kalibratielaboratoria. Buro Blauw staat geregistreerd onder nummer L400. De geaccrediteerde verrichtingen hebben enkel betrekking op de uitvoering van metingen en de analyse ervan.

Buro Blauw B.V. is lid van de Vereniging Kwaliteit Lucht. Deze vereniging zet zich in voor een permanente ontwikkeling en borging van een goede kwaliteit van luchtmetingen en bestaat uit vooraanstaande meet- en inspectie-instanties in Nederland. 
Buro Blauw heeft de derdelijnscontrole georganiseerd door de VKL bij VITO in België de onderdelen debiet en ammoniak met succes afgelegd.

Tabel 2.1 geeft een overzicht van de toegepaste meetmethoden in dit onderzoek.

Tabel 2.1 De bij het onderzoek gehanteerde meetmethoden

\begin{tabular}{|c|c|c|c|c|}
\hline Bepaling & Verrichting & Norm & Accreditatie $^{1}$ & Bijlage \\
\hline Afgasdebiet & Afgassnelheid, temperatuur, druk en vochtgehalte & ISO 10780 & Q & B \\
\hline Bepaling $\mathrm{NH}_{3}$ & $\begin{array}{l}\text { Bemonstering over gaswasflessen met } \\
\text { absorptievloeistof }\end{array}$ & NEN 2826 & $Q^{2}$ & C \\
\hline $\begin{array}{l}\text { Methaan + } \\
\text { lachgas }\end{array}$ & Bemonstering met longmethode & & & \\
\hline
\end{tabular}

1: $\quad$ De met $Q$ gemerkte verrichtingen zijn geaccrediteerd door de Raad voor Accreditatie

2 De metingen zijn uitgevoerd volgens het door de TAC-RAV goedgekeurde meetplan. Hierdoor is op sommige punten afgeweken van de NEN 2826.

De $\mathrm{NH}_{3}$ analyses zijn uitbesteed aan AL-West, een geaccrediteerd extern laboratorium. De lachgas en methaan analyses zijn uitgevoerd door het Milieulaboratorium van de Agrotechnology \& Food Sciences Group van Wageningen Universiteit en Research Center.

\subsubsection{CONCENTRATIEMETINGEN AMMONIAK}

De ammoniakmetingen zijn gedurende 24-uur uitgevoerd door middel van de absorptiemethode en natchemische analyse. Een uitgebreide beschrijving van de meetmethode wordt gegeven in bijlage C. De concentratiemetingen hebben plaatsgevonden in de ventilatiekoker. Op beide locaties was er sprake van 1 ventilatiekanaal per afdeling.

\subsubsection{Ventilatiedebiet}

Bij Van de Brandhof in Ede zijn de ventilatiedebieten continu geregistreerd door de aansturingssoftware van fabrikant Hotraco. Per ventilator werd per minuut een waarde geregistreerd. De werking van de ventilatoren is gecontroleerd met debietmetingen volgends de ISO 10780 (1994), Stationary source emissions -Measurement of velocity and volume flowrate of gas streams in ducts. In bijlage B is een gedetailleerde beschrijving van deze meetmethode gegeven. $\mathrm{Er}$ is een meetkoker geplaatst om debietmetingen uit te voeren. In figuur 2.3 wordt in een grafiek de relatie tussen de ventilatiestand en het debiet onder bedrijfsomstandigheden van lokaal 23 gegeven. 


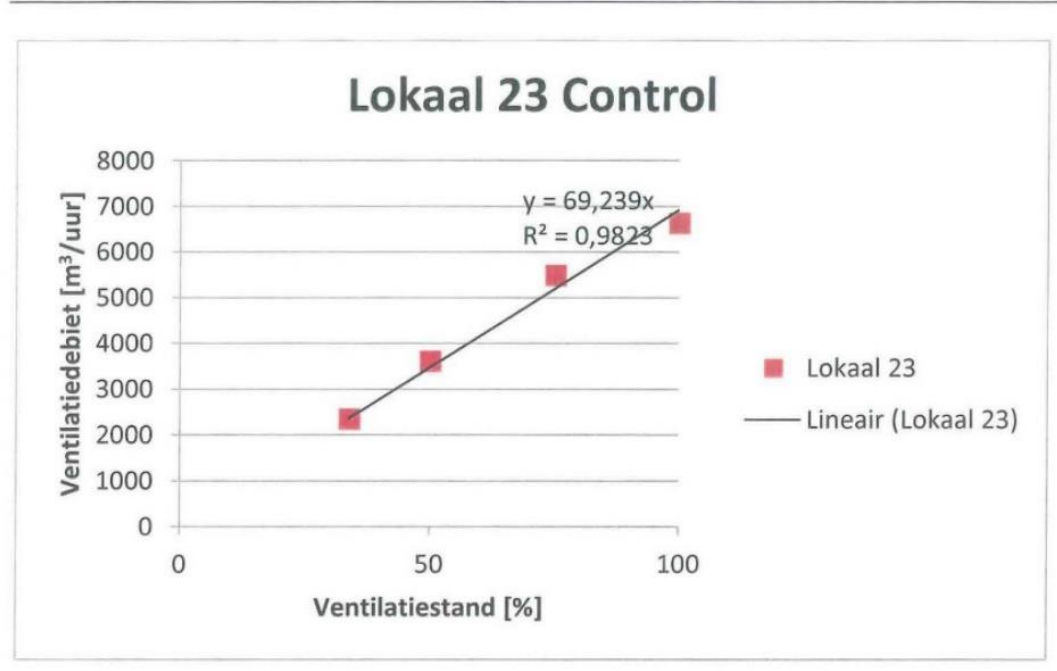

Figuur 2.3 Relatie tussen ventilatiestand en debiet van lokaal 23

In figuur 2.4 is wordt in een grafiek de relatie tussen de ventilatiestand en het debiet onder bedrijfsomstandigheden van lokaal 21 gegeven.

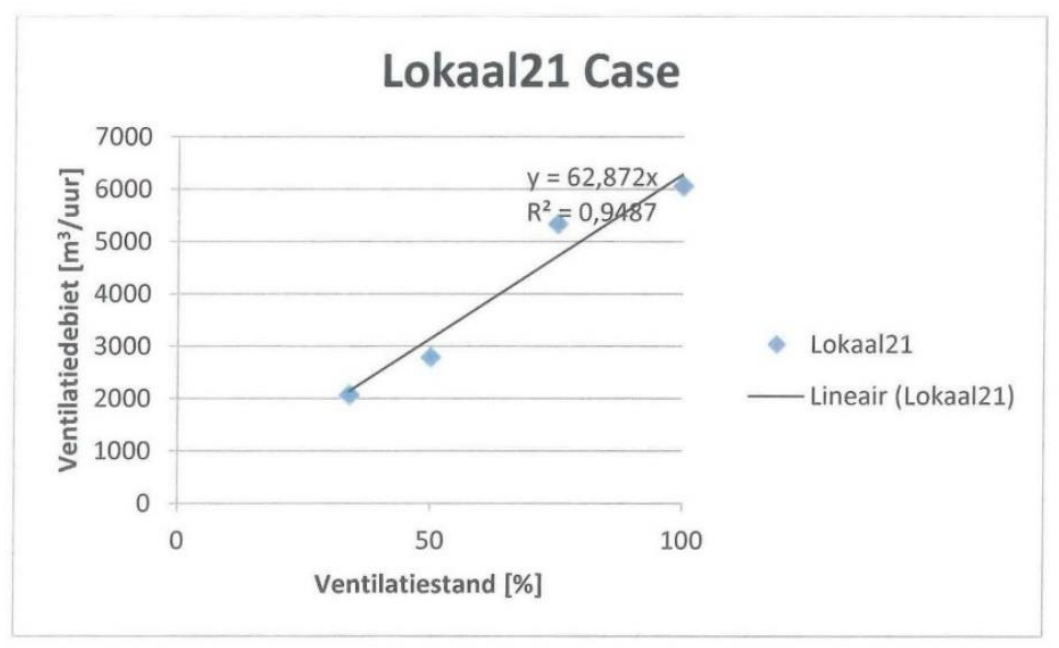

Figuur 2.4 Relatie tussen ventilatiestand en debiet van lokaal 21

Bij Van de Beek in Putten is het debiet bepaald in de bestaande ventilatiekoker. Bij de ventilatoren is de gemiddelde luchtsnelheid met een anemometer over een tijdseenheid gelogd. Voor de meting is eerst een meetvlakbeoordeling uitgevoerd aan de ventilatoren. Hier is bepaald waar de luchtsnelheid in de meetkoker gelijk is aan de gemiddelde luchtsnelheid in het meetvlak. Op die plek is de anemometer geplaatst om tijdens de 24uursmeting de luchtsnelheid te registreren. 


\subsubsection{MeEtMethode LaChGas EN MEthaAN}

De lachgas- en methaanmetingen zijn gedurende 24 uur uitgevoerd met behulp van de longmethode. De lachgas en methaan analyses zijn uitgevoerd door het Milieulaboratorium van de Agrotechnology \& Food Sciences Group van Wageningen Universiteit en Research Center.

\subsubsection{MeEtopzet}

De metingen zijn uitgevoerd volgens de case -control methodiek. Dit houdt in dat per bedrijf aan 2 vergelijkbare afdelingen gemeten is waarbij bij het ene lokaal is voorzien van een installatie voor mestbewerking in het andere lokaal geen installatie. Bij Van de Beek in Putten betreft het lokaal 3 (control) en lokaal 5 (case). Bij van de Brandhof in Ede betreft het lokaal 23 (control) en 21 (case). Naast ammoniakmetingen zijn ook de componenten lachgas en methaan meegenomen. Een productieronde van vleesvarkens in de betreffende afdeling duurt bij Van de Beek ongeveer 12 weken en bij Van de Brandhof in Ede ongeveer 17 weken. De metingen zijn verdeeld over de groeicyclus en verdeeld over de seizoen uitgevoerd, waarbij de lente en herfst als vergelijkbare seizoenen zijn beschouwd. De eerste meting is uitgevoerd op 26 juli 2011 en de laatste meting is uitgevoerd op 5 maart 2012. Ook zijn er op de meetdagen mestmonsters genomen en deze zijn ter analyse aangeboden aan het laboratorium BLGG te Wageningen. De resultaten van de mestmonsteranalyses zijn in bijlage $\mathrm{E}$ gegeven. 


\section{RESUltaten.}

\subsection{PRODUCTIERESULTATEN}

In tabel 3.1 staan de gemiddelde gegevens van de bedrijven gedurende de periode van de 6 metingen. De productiegegevens per productieronde en per bedrijf staan in de bijlagen D.1. t/m D.2.

Tabel 3.1 Gemiddelde gegevens van de 2 bedrijven gedurende de meetperiode

\begin{tabular}{|c|c|c|c|c|}
\hline & \multicolumn{2}{|c|}{ Van de Beek Putten } & \multicolumn{2}{|c|}{ Van de Brandhof Ede } \\
\hline & $\begin{array}{l}\text { Control } \\
\text { Lokaal } 3\end{array}$ & $\begin{array}{c}\text { Case } \\
\text { Lokaal } 5\end{array}$ & $\begin{array}{l}\text { Control } \\
\text { Lkal } 23\end{array}$ & $\begin{array}{c}\text { Case } \\
\text { Lkaal } 21\end{array}$ \\
\hline Aantal varkens in per afdeling & 80 & 80 & 96 & 96 \\
\hline Aantal hokken per stal & 8 & 8 & 8 & 8 \\
\hline Aantal dieren per hok & 10 & 10 & 12 & 12 \\
\hline Opleggewicht $(\mathrm{kg})$ & 22,2 & 23,2 & 24,2 & 24,7 \\
\hline Uitval (\%) & 2,5 & 1,7 & 2,5 & 2,0 \\
\hline Aflevergewicht (g) & 116 & 116 & 91,4 & 92,1 \\
\hline $\begin{array}{l}\text { Gezondheidsproblemen voor } \\
\text { meetperiode[\%] }\end{array}$ & 18,1 & 15,0 & n.b. & n.b. \\
\hline $\begin{array}{l}\text { Gezondheidproblemen tijdens } \\
\text { meetperiode }\end{array}$ & 9,2 & 3,8 & n.b. & n.b. \\
\hline Bezettingsgraad $\left(/ \mathrm{m}^{2}\right)$ & 0,9 & 0,9 & 0,8 & 0,8 \\
\hline Groei per dag (g) & 772 & 789 & 824 & 804 \\
\hline Totale hoeveelheid verstrekt voer $(\mathrm{kg})$ & 26.468 & 25.449 & 21.197 & 22.143 \\
\hline Hoeveelheid verstrekt water $(I)$ & n.b. ${ }^{1}$ & n.b. & 55,960 & 58.457 \\
\hline Water-voerverhouding (-) & n.b. & n.b. & $25 \%$ ds & $25 \%$ ds \\
\hline
\end{tabular}

1. N.b. $=$ niet bekend

Opgemerkt wordt dat bij Van de Beek in Putten de varkens bij opleg eerst in twee andere lokalen verblijven voordat ze naar lokaal 3 en 5 gaan. De varkens verblijven per productieronde ongeveer 12 weken in de lokaal 3 en 5 . Het medicijngebruik op koppelniveau is gegeven in bijlage D.1 en D.2.

Uit de tabel en de bijlagen D.1 en D.2 volgt dat bij beide bedrijven sprake is van kleine verschillen in landbouwkundige randvoorwaarden tussen de case en control afdeling. Het aantal varkens per afdeling, de hokbezetting, het drinkwaterverbruik, het verstrekte voer en de veterinaire behandeling waren voor de case en control gelijk. De lengte van de productieronde, de groei per dag, het aflevergewicht, de hoeveelheid verstrekt voer en het percentage uitval verschilt bij beide bedrijven minder dan $5 \%$ tussen case en control. Hieruit wordt geconcludeerd dat bij beide bedrijven voor de case en control afdeling voor wat betreft de landbouwkundige randvoorwaarden vergelijkbaar zijn. 


\subsection{Spreiding metingen}

De metingen zijn verspreid over de seizoenen en de groeicyclus van de dieren uitgevoerd. In figuur 3.1 zijn de meetdata van de metingen en de verdeling over de meetperiode gegeven.

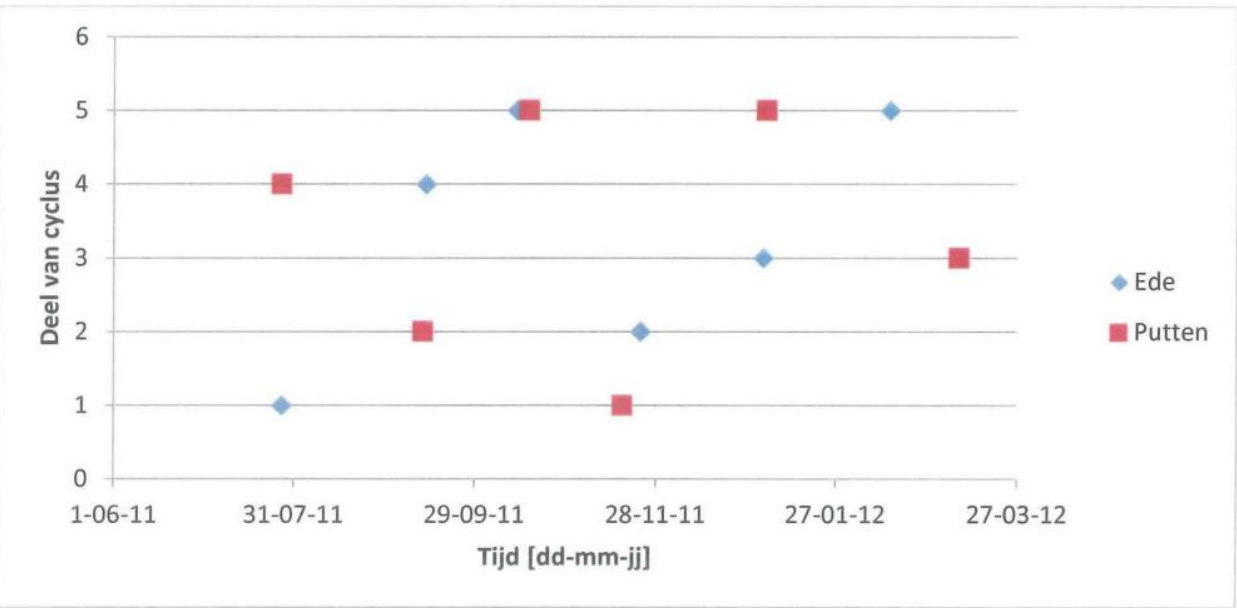

Figuur 3.1 Spreiding van de metingen over de meetperiode

$\mathrm{Er}$ is bij beide bedrijven niet gemeten in het zesde deel van de groeicyclus omdat de kop dan al uit de stal is en er een ongelijk aantal varkens in beide hokken aanwezig is. Hierdoor ontstaat een onvergelijkbare situatie.

$\mathrm{Er}$ is per bedrijf twee maal in het vijfde deel van de groeifase gemeten. Bij Van de Brandhof in Ede waar de varkens gemiddeld 17 weken in lokaal 21 en 23 verblijven, is de groeicyclus opgedeeld in delen van 3 weken. Omdat bij Van de Beek in Putten de varkens na de opleg eerst in twee andere lokalen vertoeven en pas later naar lokaal 3 en 5 gaan, bedraagt de verblijftijd in lokaal 3 en 5 ongeveer 12 weken. De groeifase is opgedeeld delen van 2 weken.

Er zijn in totaal 4 metingen in de zomer, 4 metingen in de winter en 4 metingen in het voor- of najaar uitgevoerd.

Ook volgt uit de figuur dat de metingen op de 2 bedrijven voor wat betreft de groeifase redelijk verdeeld over de seizoenen zijn uitgevoerd. Hiermee is voldaan aan de organisatorische vereisten voor de uitvoering van het onderzoek. Bij de eerste meting bij Van de Beek was de kop al uit lokaal 3 (control). Het gewijzigde dieraantal is meegenomen in de berekening van de emissiefactor. 


\subsection{Resultaten van de ventilatiedebietmetingen}

In tabel 3.3 zijn de resultaten van de ventilatiedebieten gegeven.

Tabel 3.3 Resultaten van de metingen van het ventilatiedebiet en de staltemperatuur.

\begin{tabular}{|c|c|c|c|c|c|c|}
\hline \multirow{2}{*}{$\begin{array}{l}\text { Datum } \\
\text { [dd-mm-jj] }\end{array}$} & \multirow[t]{2}{*}{ Locatie } & \multirow{2}{*}{$\begin{array}{c}\text { Deel in } \\
\text { cyclus } \\
{[-]}\end{array}$} & \multicolumn{2}{|c|}{ Control } & \multicolumn{2}{|c|}{ Case } \\
\hline & & & $\begin{array}{l}\text { Debiet } \\
{\left[\mathrm{m}_{0}^{3} / \mathrm{u}\right]}\end{array}$ & $\begin{array}{c}\text { Temperatuur } \\
{\left[{ }^{\circ} \mathrm{C}\right]}\end{array}$ & $\begin{array}{l}\text { Debiet } \\
{\left[\mathrm{m}_{0}{ }^{3} / \mathrm{u}\right]}\end{array}$ & $\begin{array}{c}\text { Temperatuur } \\
{\left[{ }^{\circ} \mathrm{C}\right]}\end{array}$ \\
\hline $26-07-11$ & Van de Beek & 4 & 2833 & 26,4 & 1876 & 28,7 \\
\hline $12-09-11$ & Van de Beek & 2 & 2049 & 27,6 & 1760 & 27,6 \\
\hline $17-10-11$ & Van de Beek & 5 & 2251 & 25,9 & 1936 & 25,4 \\
\hline $23-11-11$ & Van de Beek & 1 & 2184 & 25,0 & 1937 & 24,0 \\
\hline $03-01-12$ & Van de Beek & 5 & 1792 & 24,1 & 1768 & 23,9 \\
\hline \multirow[t]{2}{*}{$05-03-12$} & Van de Beek & 3 & 2275 & 21,5 & 2139 & 21,2 \\
\hline & Gemiddeld & & 2231 & 25,1 & 1903 & 25,1 \\
\hline $27-07-11$ & Van de Brandhof & 1 & 1571 & 27,1 & 1191 & 27,4 \\
\hline $14-09-11$ & Van de Brandhof & 4 & 2639 & 25,4 & 2063 & 25,9 \\
\hline $13-10-11$ & Van de Brandhof & 5 & 2587 & 24,0 & 2308 & 23,4 \\
\hline $07-12-11$ & Van de Brandhof & 2 & 1257 & 24,4 & 875 & 24,8 \\
\hline $05-01-12$ & Van de Brandhof & 3 & 1791 & 24,4 & 1322 & 23,7 \\
\hline \multirow[t]{2}{*}{$10-02-12$} & Van de Brandhof & 5 & 1200 & 21,6 & 1097 & 21,4 \\
\hline & Gemiddeld & & 1841 & 24,5 & 1476 & 24,4 \\
\hline
\end{tabular}

Uit de tabel volgt dat er sprake is van een positieve correlatie $(R=0,3)$ tussen de groeifase van het dier en het ventilatiedebiet van de stallen. Dit is in overeenstemming met de verwachtingen.

Ook is sprake van en positieve correlatie $(R=0,3)$ tussen het seizoen en het ventilatiedebiet van de stallen. In de winter is het debiet het laagst en in de zomer het hoogst. Ook dit is in overeenstemming met de verwachting.

Uit de tabel volgt verder dat zowel bij van de Beek in Putten, als bij van de Brandhof het ventilatiedebiet in de control afdeling groter dan in de case afdeling. De temperatuur in de case en control afdelingen in Putten en Ede is echter gelijk. 


\subsection{Resultaten ammoniakemissies}

In tabel 3.4 zijn de resultaten van de ammoniakemissiemetingen bij Van de Beek in Putten weergegeven.

Tabel 3.4 Resultaten van de ammoniakemissiemetingen bij Van de Beek in Putten

\begin{tabular}{cccc}
\hline \multicolumn{3}{c}{$\begin{array}{c}\text { Jaaremissie [kg/dier*i] } \\
\text { Van de Beek Putten }\end{array}$} \\
\hline $\begin{array}{c}\text { Deel van } \\
\text { cyclus }\end{array}$ & $\begin{array}{c}\text { Lokaal 3 } \\
\text { Control }\end{array}$ & $\begin{array}{c}\text { Lokaal 5 } \\
\text { Case }\end{array}$ & $\begin{array}{c}\text { Rendement } \\
{[\%]}\end{array}$ \\
\hline 4 & 11,3 & 6,2 & 45 \\
2 & 5,5 & 3,5 & 35 \\
5 & 7,2 & 4,3 & 39 \\
1 & 5,8 & 4,2 & 26 \\
5 & 6,2 & 4,7 & 25 \\
3 & 4,8 & 2,9 & 38 \\
\hline Gemiddeld & $\mathbf{6 , 8}$ & $\mathbf{4 , 3}$ & $\mathbf{3 5}$ \\
\hline
\end{tabular}

In tabel 3.5 zijn de resultaten van de ammoniakemissiemetingen bij Van de Brandhof in Ede weergegeven.

Tabel 3.5 Resultaten van de ammoniakemissiemetingen bij Van de Brandhof in Ede.

\begin{tabular}{cccc}
\hline \multicolumn{3}{c}{$\begin{array}{c}\text { Jaaremissie [kg/dier*i] } \\
\text { Van de Brandhof Ede }\end{array}$} \\
\hline Deel van & $\begin{array}{c}\text { Lokaal 23 } \\
\text { Control }\end{array}$ & $\begin{array}{c}\text { Lokaal 21 } \\
\text { Case }\end{array}$ & $\begin{array}{c}\text { Rendement } \\
{[\%]}\end{array}$ \\
\hline 4 & 1,4 & 1,0 & 27 \\
2 & 1,9 & 1,5 & 21 \\
5 & 3,0 & 2,3 & 25 \\
1 & 1,1 & 1,0 & 7 \\
5 & 1,4 & 1,2 & 10 \\
3 & 2,1 & 1,8 & 11 \\
\hline Gemiddeld & $\mathbf{1 , 8}$ & $\mathbf{1 , 5}$ & $\mathbf{1 7}$ \\
\hline
\end{tabular}

Uit tabel 3.4 volgt dat de gemiddelde ammoniakemissiereductie bij Van de Beek in Putten door gebruik de installatie voor de mestbewerking gelijk is aan $35 \%$. Uit tabel 3.5 volgt dat de gemiddelde ammoniakemissiereductie bij Van de Brandhof in Ede door toepassing van de installatie voor mestbewerking gelijk is aan $17 \%$. De gemiddeld gemeten ammoniakreductie van beide bedrijven bedraagt $26 \%$.

Tijdens de leegstand tussen twee cycli in zijn door Dijkstra Agrimarketing met een elektrochemisch handapparaat ammoniakconcentratiemetingen verricht op verschillende plekken in de lokalen. In tabel 3.6 zijn de gemiddelde waardes van deze metingen gegeven. De gedetailleerde gegevens zijn in bijlage F gegeven. 


\section{blauw}

Tabel 3.6 Resultaten van de elektrochemische ammoniakconcentratiemetingen.

\begin{tabular}{ccccc}
\hline & & Ammoniakconcentraties [ppm] & \\
Bedrijf & $\begin{array}{c}\text { Datum } \\
\text { [dd-mm-ji] }\end{array}$ & Case & Control & Rendement \\
[\%]
\end{tabular}

Ook bij deze metingen blijkt een verschil in ammoniakverwijderingsrendement tussen de twee bedrijven. Het gemeten rendement Bij Van de Beek in Putten is met de ammoniakmeter is hoger dan bij de officiële metingen. Dit kan verklaard worden doordat de totale ammoniakemissie is samengesteld uit de putemissie en de hokemissie. Tijdens de leegstand wordt het aandeel van de putemissie hoger ten opzichte van de hokemissie. De installatie voor mestbewerking heeft alleen een ammoniakemissiereducerende werking op de putemissie.

\subsection{Resultaten methaan- en lachgasemissies}

In tabel 3.7 zijn de resultaten van de methaanemissiemetingen bij Van de Beek in Putten weergegeven.

Tabel 3.7 Resultaten van de methaanemissiemetingen bij Van de Beek in Putten

\begin{tabular}{cccc}
\hline \multicolumn{3}{c}{$\begin{array}{c}\text { Jaaremissie [kg/dier*i] } \\
\text { Van de Beek Putten }\end{array}$} \\
\hline $\begin{array}{c}\text { Deel van } \\
\text { cyclus }\end{array}$ & $\begin{array}{c}\text { Lokaal 3 } \\
\text { Control }\end{array}$ & Lokaal 5 & Rendement \\
\hline 4 & 21 & 23 & {$[\%]$} \\
2 & 21 & 21 & -14 \\
5 & 25 & 19 & 3 \\
1 & 14 & 18 & 22 \\
5 & 24 & 18 & -29 \\
3 & 23 & 19 & 25 \\
\hline Gemiddeld & $\mathbf{2 2}$ & $\mathbf{1 9}$ & 19 \\
\hline
\end{tabular}

In tabel 3.8 zijn de resultaten van de methaanemissiemetingen bij Van de Brandhof in Ede weergegeven. 
Tabel 3.8 Resultaten van de methaanemissiemetingen bij Van de Brandhof in Ede.

\begin{tabular}{cccc}
\hline \multicolumn{3}{c}{$\begin{array}{c}\text { Jaaremissie [kg/dier*j] } \\
\text { Van de Brandhof Ede }\end{array}$} \\
\hline $\begin{array}{c}\text { Deel van } \\
\text { cyclus }\end{array}$ & $\begin{array}{c}\text { Lokaal 23 } \\
\text { Control }\end{array}$ & $\begin{array}{c}\text { Lokaal 21 } \\
\text { Case }\end{array}$ & $\begin{array}{c}\text { Rendement } \\
{[\%]}\end{array}$ \\
\hline 4 & 1,6 & 1,0 & 37 \\
2 & 2,5 & 1,9 & 25 \\
5 & 3,3 & 3,4 & -3 \\
1 & 3,9 & 1,9 & 51 \\
5 & 3,3 & 1,6 & 50 \\
3 & 4,3 & 2,1 & 52 \\
\hline Gemiddeld & 3,1 & $\mathbf{2 , 0}$ & $\mathbf{3 5}$ \\
\hline
\end{tabular}

Uit tabel 3.7 volgt dat de gemiddelde methaanemissiereductie bij Van de Beek in Putten door gebruik de installatie voor de mestbewerking gelijk is aan $4 \%$. Uit tabel 3.8 volgt dat de gemiddelde methaanemissiereductie bij Van de Brandhof in Ede door toepassing van de installatie voor mestbewerking gelijk is aan $35 \%$. De gemiddeld gemeten methaanemissiereductie van beide bedrijven bedraagt $20 \%$.

In tabel 3.9 zijn de resultaten van de lachgasemissiemetingen bij Van de Beek in Putten weergegeven.

Tabel 3.9 Resultaten van de lachgasemissiemetingen bij Van de Beek in Putten

\begin{tabular}{cccc}
\hline \multicolumn{3}{c}{$\begin{array}{c}\text { Jaaremissie [kg/dier*j] } \\
\text { Van de Beek Putten }\end{array}$} \\
\hline $\begin{array}{c}\text { Deel van } \\
\text { cyclus }\end{array}$ & $\begin{array}{c}\text { Lokaal 3 } \\
\text { Control }\end{array}$ & Case & Rendement \\
\hline 4 & 0,17 & 0,16 & 5 \\
2 & 0,14 & 0,14 & -2 \\
5 & 0,21 & 0,20 & 4 \\
1 & 0,18 & 0,20 & 13 \\
5 & 0,16 & 0,18 & -11 \\
3 & 0,16 & 0,17 & -4 \\
\hline Gemiddeld & $\mathbf{0 , 1 7}$ & $\mathbf{0 , 1 8}$ & -4 \\
\hline
\end{tabular}

In tabel 3.10 zijn de resultaten van de lachgasemissiemetingen bij Van de Brandhof in Ede weergegeven. 
Tabel 3.10 Resultaten van de lachgasemissiemetingen bij Van de Brandhof in Ede.

\begin{tabular}{cccc}
\hline \multicolumn{3}{c}{$\begin{array}{c}\text { Jaaremissie [kg/dier }{ }^{*} \text { j] } \\
\text { Van de Brandhof Ede }\end{array}$} \\
\hline $\begin{array}{c}\text { Deel van } \\
\text { cyclus }\end{array}$ & $\begin{array}{c}\text { Lokaal 23 } \\
\text { Control }\end{array}$ & $\begin{array}{c}\text { Lokaal 21 } \\
\text { Case }\end{array}$ & $\begin{array}{c}\text { Rendement } \\
{[\%]}\end{array}$ \\
\hline 4 & 0,10 & 0,08 & 23 \\
2 & 0,15 & 0,12 & 24 \\
5 & 0,19 & 0,18 & 8 \\
1 & 0,11 & 0,07 & 38 \\
5 & 0,15 & 0,11 & 23 \\
3 & 0,08 & 0,08 & 7 \\
\hline Gemiddeld & $\mathbf{0 , 1 3}$ & $\mathbf{0 , 1 0}$ & $\mathbf{2 0}$ \\
\hline
\end{tabular}

Uit tabel 3.9 volgt dat de gemiddelde lachgasemissiereductie bij Van de Beek in Putten door gebruik de installatie voor de mestbewerking gelijk is aan $-4 \%$. Uit tabel 3.10 volgt dat de gemiddelde lachgasemissiereductie bij Van de Brandhof in Ede door toepassing van de installatie voor mestbewerking gelijk is aan $20 \%$. De gemiddeld gemeten lachgasemissiereductie van beide bedrijven bedraagt $8 \%$. 


\section{DISCUSSIE}

In dit hoofdstuk worden de effecten op de gemeten ammoniakemissiereductie van verschillen in landbouwkundige randvoorwaarden tussen de case en control afdelingen bij de beide bedrijven besproken. Hieronder wordt ingegaan op de effecten van:

1. het verschil in gewicht van de dieren tussen de case en control afdeling;

2. het verschil in ventilatiedebiet van de case en control afdeling;

3. het verschil in de samenstelling van de mest tussen de case en control afdeling;

4. verschillen in ammoniakemissiereductie tussen de beide bedrijven;

5. relatie ammoniakemissiereductie en werkingsmechanisme;

6. reductie van methaan en lachgasemissies.

Op basis van de bespreking van bovenstaande punten worden aanbevelingen voor verder onderzoek gedaan.

\section{Ad 1. Verschil in gewicht}

In tabel 4.1 wordt het gewicht van de dieren in beide afdelingen bij de beide bedrijven met elkaar vergeleken. 


\section{blauw}

Tabel 4.1 Vergelijking aantal dieren en gewicht dieren in de control en case afdeling

\begin{tabular}{|c|c|c|c|c|c|c|c|}
\hline \multirow[t]{2}{*}{ Meting } & \multirow[t]{2}{*}{ Afdeling } & \multirow{2}{*}{$\begin{array}{l}\text { Aantal } \\
\text { varkens }\end{array}$} & \multicolumn{2}{|c|}{ Datum } & \multicolumn{2}{|c|}{ Gewicht [kg] } & \multirow{2}{*}{$\begin{array}{c}\text { Verschil } \\
\text { [\%] }\end{array}$} \\
\hline & & & Opleg & Meting & Opleg & Meting & \\
\hline \multirow{3}{*}{1} & Van de Beek & & & & & & \\
\hline & Control & 78 & $8-7-2011$ & $26-07-2011$ & 16,0 & 109 & $-11 \%$ \\
\hline & Case & 78 & $29-6-2011$ & $26-07-2011$ & 15,2 & 97 & \\
\hline \multirow[t]{2}{*}{2} & Control & 79 & $8-7-2011$ & $12-09-2011$ & 16,0 & 67 & $-11 \%$ \\
\hline & Case & 79 & $29-6-2011$ & $12-09-2011$ & 15,2 & 75 & \\
\hline \multirow[t]{2}{*}{3} & Control & 79 & $14-9-2011$ & $17-10-2011$ & 25,6 & 96 & $-7 \%$ \\
\hline & Case & 79 & 29-9-2011 & $17-10-2011$ & 31,8 & 102 & \\
\hline \multirow[t]{2}{*}{4} & Control & 79 & $14-9-2011$ & $23-11-2011$ & 25,6 & 81 & $7 \%$ \\
\hline & Case & 80 & 29-9-2011 & $23-11-2011$ & 31,8 & 75 & \\
\hline \multirow[t]{2}{*}{5} & Control & 79 & $21-12-2011$ & 3-01-2012 & 25,9 & 109 & $2 \%$ \\
\hline & Case & 79 & 7-12-2011 & $3-01-2012$ & 24,9 & 106 & \\
\hline \multirow[t]{4}{*}{6} & Control & 79 & $21-12-2011$ & 5-03-2012 & 16,0 & 82 & $-14 \%$ \\
\hline & Case & 80 & $7-12-2011$ & 5-03-2012 & 15,2 & 94 & \\
\hline & Gemiddeld & & & & & & $-6 \%$ \\
\hline & Van de Bran & Ihof & & & & & \\
\hline \multirow[t]{2}{*}{1} & Control & 96 & $5-7-2011$ & $27-07-2011$ & 22 & 40 & $13 \%$ \\
\hline & Case & 96 & $13-7-2011$ & 27-07-2011 & 23 & 35 & \\
\hline \multirow[t]{2}{*}{2} & Control & 96 & $5-7-2011$ & $14-09-2011$ & 22 & 80 & $6 \%$ \\
\hline & Case & 96 & $13-7-2011$ & $14-09-2011$ & 23 & 76 & \\
\hline \multirow[t]{2}{*}{3} & Control & 96 & $5-7-2011$ & $13-10-2011$ & 22 & 105 & $4 \%$ \\
\hline & Case & 96 & $13-7-2011$ & $13-10-2011$ & 23 & 100 & \\
\hline \multirow[t]{2}{*}{4} & Control & 96 & 2-11-2011 & $7-12-2011$ & 25 & 52 & $9 \%$ \\
\hline & Case & 96 & $9-11-2011$ & $7-12-2011$ & 25 & 48 & \\
\hline \multirow[t]{2}{*}{5} & Control & 96 & 2-11-2011 & $5-1-2012$ & 25 & 73 & $5 \%$ \\
\hline & Case & 96 & $9-11-2011$ & $5-1-2012$ & 25 & 70 & \\
\hline \multirow[t]{3}{*}{6} & Control & 96 & $2-11-2011$ & $10-02-2012$ & 25 & 103 & $2 \%$ \\
\hline & Case & 96 & $9-11-2011$ & $10-02-2012$ & 25 & 101 & \\
\hline & Gemiddeld & & & & & & $5 \%$ \\
\hline
\end{tabular}

Uit de tabel volgt dat het aantal dieren in de case en control afdeling van de beide bedrijven bij alle metingen gelijk was Ook is er sprake van een klein gewichtsverschil tussen de dieren van de beide afdelingen. Bij van de Beek was het gewicht van de dieren in de control afdeling gemiddeld $6 \%$ hoger dan in de case afdeling. Hierdoor wordt de gemeten ammoniakemissiereductie bij van de Beek enigszins overschat.

$\mathrm{Bij}$ van de Brandhof is sprake van een nagenoeg omgekeerd effect. Hier is het gewicht van de varkens in de case afdeling gemiddeld $5 \%$ groter dan in de control afdeling. Hierdoor wordt de gemeten ammoniakemissiereductie bij van de Brandhof enigszins onderschat.

Overall heeft het gewichtsverschil van de dieren in de control en case afdeling nauwelijks invloed op de gemeten ammoniakemissiereductie. 


\section{Ad 2. Verschil in ventilatiedebiet}

In paragraaf 3.3 is geconstateerd dat bij beide bedrijven het ventilatiedebiet in de control afdeling groter is als in de case afdeling. De temperatuur in de case en control afdelingen in Putten en Ede is wel gelijk. In figuur 4.1 wordt het effect op de ammoniakemissiereductie van het verschil in ventilatiedebiet tussen de control en case afdeling grafisch weergegeven.

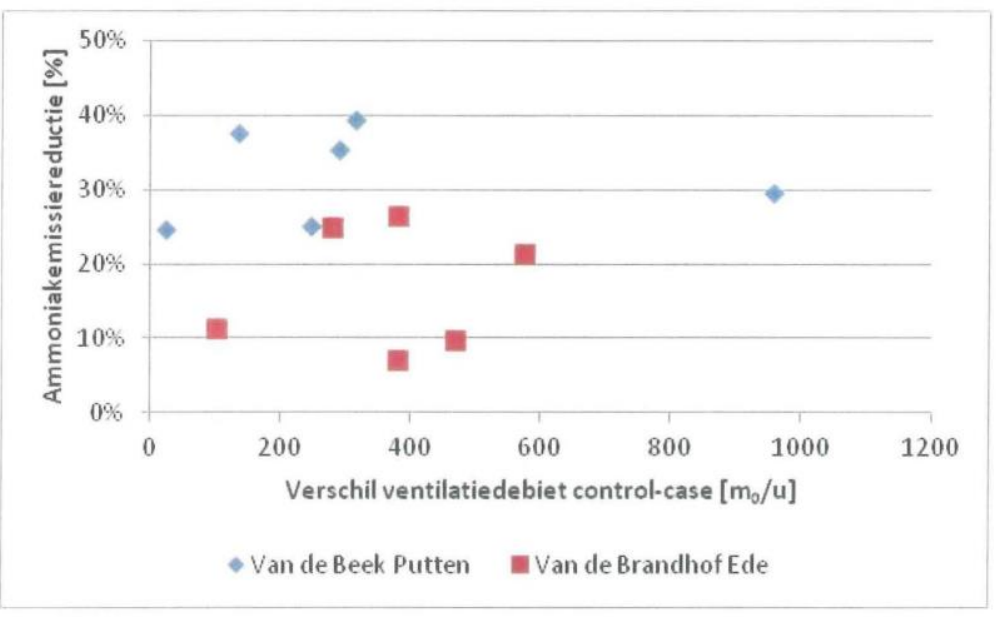

Figuur 4.1 Relatie tussen het verschil in ventilatiedebiet tussen de control en case afdeling en de ammoniakemissiereductie

Uit de figuur blijkt duidelijk dat er geen systematisch effect van het verschil in ventilatiedebiet op de ammoniakemissiereductie gevonden wordt. De correlatiecoëfficiënt tussen beide grootheden is gelijk aan $-0,03$.

Geconcludeerd wordt dat het verschil in ventilatiedebiet geen invloed heeft op de gemeten ammoniakemissiereductie. Dit is in lijn met het feit dat er geen verschil in staltemperatuur is opgestreden tussen de case en control afdelingen.

\section{Ad 3. Verschil in samenstelling van de mest}

In tabel 4.2 wordt de samenstelling van de mest bij van de Beek en van de Brandhof met elkaar vergeleken. Tevens wordt gekeken naar het verschil in mestsamenstelling tussen de control en case afdeling per bedrijf. Tot slot wordt ook de "gemiddelde" samenstelling van de mest gegeven. Hierbij wordt opgemerkt dat in de vrij toegankelijke literatuur nauwelijks publicaties aanwezig zijn over de samenstelling van onbehandelde mest. In geen van de gevonden rapporten over de ammoniakemissiereductie van andere systemen is informatie over de samenstelling van de mest opgenomen. Ook is geen informatie gevonden over de spreiding in samenstelling van onbehandelde vleesvarkensmest. 
Tabel 4.2 Vergelijking van de samenstelling van de mest in de control en case afdeling en de gemiddelde samenstelling van dunne vleesvarkensmest ${ }^{(1)}$.

\begin{tabular}{|c|c|c|c|c|c|c|}
\hline \multirow[t]{2}{*}{ Samenstelling mest } & & \multicolumn{2}{|c|}{ Van der Beek } & \multicolumn{2}{|c|}{ Van de Brandhof } & \multirow{2}{*}{$\begin{array}{l}\text { Gemiddelde } \\
\text { samenstelling }\end{array}$} \\
\hline & & control & case & control & case & \\
\hline Droge stof & [g DS/kg] & 121 & 94 & 132 & 132 & 93 \\
\hline Ruwe as & [g RAS/kg] & 32 & 23 & 27 & 28 & \\
\hline Organische stof & [g OS/kg] & 90 & 71 & 105 & 104 & 43 \\
\hline Stikstof & [g N/kg] & 9 & 8 & 9 & 9 & 7 \\
\hline $\mathrm{C} / \mathrm{N}$ ratio & {$[-]$} & 4 & 4 & 5 & 5 & \\
\hline Stikstof-ammoniak & {$\left[\mathrm{g} \mathrm{N}-\mathrm{NH}_{3} / \mathrm{kg}\right]$} & 5 & 4 & 5 & 5 & \\
\hline Stikstof-organisch & [g N-org/kg] & 4 & 3 & 4 & 4 & 3 \\
\hline Fosfor & [g P/kg] & 3 & 2 & 2 & 2 & \\
\hline Fosfaat & {$\left[\mathrm{g} \mathrm{P}_{2} \mathrm{O}_{5} / \mathrm{kg}\right]$} & 7 & 5 & 5 & 5 & 5 \\
\hline Kalium & {$[\mathrm{g} \mathrm{K} / \mathrm{kg}]$} & 6 & 5 & 5 & 5 & \\
\hline Kali & {$\left[\mathrm{g} \mathrm{K}_{2} \mathrm{O} / \mathrm{kg}\right]$} & 7 & 5 & 6 & 7 & 6 \\
\hline Magnesium & [g Mg/kg] & 2 & 1 & 1 & 1 & \\
\hline Magnesia & [g MgO/kg] & 3 & 2 & 2 & 2 & 2 \\
\hline Natrium & [g Na/kg] & 1 & 1 & 1 & 1 & \\
\hline Natron & {$\left[\mathrm{g} \mathrm{Na}{ }_{2} \mathrm{O} / \mathrm{kg}\right]$} & 2 & 1 & 2 & 2 & 1 \\
\hline
\end{tabular}

Uit de tabel worden de volgende conclusies getrokken:

- Het droge stofgehalte en het gehalte organisch stof zijn voor zowel de control en case afdeling bij van de Beek lager dan bij van de Brandhof.

- Het droge stofgehalte en het gehalte organische stof zijn in de control afdeling bij van de Beek lager dan in de case afdeling, terwijl deze bij van de Brandhof in beide afdelingen gelijk zijn.

- Alle mestparameters, met uitzondering van de $\mathrm{C} / \mathrm{N}$-verhouding en het stikstofammoniak, zijn bij van de Beek in de control afdeling 15-25\% hoger dan in de case afdeling. Bij van de Brandhof is de waarde van alle mestparameters, inclusies de $\mathrm{C} / \mathrm{N}$-verhouding in beide afdelingen gelijk.

- Door de lage ammoniakemissie bij van de Brandhof sprake van absoluut kleine verschillen in hoeveelheden in de mest en zijn verschillen moeilijker aantoonbaar.

Hieronder wordt op de oorzaken van bovenstaande verschillen ingegaan. Tevens wordt het effect van de geconstateerde verschillen op de gemeten ammoniakemissiereductie besproken.

\section{Drogestofgehalte mest}

Het hogere drogestofgehalte van de mest bij van de Brandhof kan veroorzaakt zijn door het effect van het nieuwheid van de stal bij van de Brandhof. Nieuw beton heeft een hygroscopische werking en zuigt vocht uit de mest aan. De metingen zijn uitgevoerd na de eerste mestronde in de stal. Het is onbekend hoelang de hygroscopische werking van nieuw beton aanhoudt. 


\section{Verschillen tussen droge stofgehalte tussen case en control}

Bij van de Beek wordt een duidelijk verlaging van het droge stof en organisch stofgehalte in de case afdeling gevonden ten opzichte van de control afdeling. Bij van de Brandhof worden geen verschillen gevonden.

Eerder is al beschreven dat de landbouwkundige randvoorwaarden bij van de Beek gelijk zijn bij de control en case afdeling. Het verschil in droge stof kan niet verklaard worden uit een verschil in drinkwatervoorzieningen. De verlaging van het droge stofgehalte en het organisch stofgehalte in de case afdeling bij van de Beek is wel in lijn met het in §2.3 beschreven werkingsmechanisme.

Hierbij is het de vraag waarom deze verlaging niet optreedt bij van de Brandhof. Een mogelijke verklaring is de hierboven genoemde hygroscopische werking van het nieuwe beton bij van de Brandhof. Uit tabel 4.2 blijkt dat het droge stofgehalte bij van de Brandhof, en in veel mindere mate bij van de Beek, duidelijk verhoogd is ten opzichte van het gemiddelde. Door de vochtaanzuigende werking van het beton kan het droge stofgehalte verlagend effect van de mestverwerkingsinstallatie bij van de Brandhof te geniet gedaan zijn.

\section{Verschillen in andere mestparameters}

De overige mestparameters, met uitzondering van de $\mathrm{C}-\mathrm{N}$ verhouding en het stikstof ammoniak verschillen weinig. Dit geldt zowel ten opzichte van de gemiddelde samenstelling, als voor verschillen tussen de control en case per bedrijf en verschillen tussen de bedrijven.

Dit is in overeenstemming met het beschreven werkingsmechanisme in §2.3. Door de toevoeging van het minerale mengsel worden droge stof en organische stof afgebroken en wordt ammoniak-stikstof in de mest gebonden. Met andere woorden de $\mathrm{C} / \mathrm{N}$ verhouding in de behandelde mest neemt af ten opzichte van de onbehandelde mest. Dit is wat te zien is in de data van tabel 4.2.

De verschillen in de mestsamenstelling tussen de control en case afdeling bij van de Beek zijn niet voor alle mestparameters gelijk. Bij magnesium en natrium is het verschil statistisch niet significant. Dit betekent dat de verschillen niet veroorzaakt kunnen zijn door het verdunnen van de mest, omdat dan alle parameters in de case afdeling gelijke mate moeten afnemen ten opzichte van de control afdeling. Ook kan, gezien het fluctuerende droge stofgehalte geen sprake zijn van een structurele lekkage van drinkwater bij van de Beek.

Samenvattend wordt geconcludeerd dat de geconstateerde verschillen in de samenstelling van de mest bij van de Beek overeenstemmen met het omschreven werkingsmechanisme van de installatie voor mestbewerking. Bij van de Brandhof heeft de hygroscopische werking van het relatief nieuwe beton een grote invloed op het droge stofgehalte van de mest. Dit is een mogelijke verklaring dat de samenstelling van de mest bij de control en case afdeling bij van de Brandhof niet van elkaar verschillen. 


\section{Ad 4. Verschil in ammoniakreductie tussen de bedrijven}

Uit de metingen is een duidelijk verschil naar voren gekomen in de ammoniakemissiereductie bij de beide bedrijven. Bij Van de Beek in Putten is een gemiddelde reductie gemeten van $35 \%$ en bij Van de Brandhof in Ede van 17\%. Uit het voorgaande kan geconcludeerd worden dat dit verschil in werking toegeschreven kan worden aan de invloed van het nieuwe beton op de mestsamenstelling bij van de Brandhof in Ede. Bij Van de Brandhof is een gemiddelde ammoniak emissiefactor in de referentieafdeling gemeten van $1,8 \mathrm{~kg} \mathrm{~N}$ per dierplaats per jaar. Dit terwijl voor het type stal in de RAV-lijst een emissiefactor van $3 \mathrm{~kg} \mathrm{~N}$ per dierplaats per jaar. De ammoniakemissie vindt plaats in de stal en in de put. De installatie voor mestbewerking beïnvloedt vooral de putemissie. Als, zoals bij van de Brandhof het geval is, de overall ammoniakemissie al aanzienlijk verlaagd is, heeft het verlagen van de putemissie door de installatie van mestbewerking nog slechts een beperkt effect op de totale emissie van de stal.

\section{Ad 5. Relatie ammoniakreductie en werkingsmechanisme}

De gemeten emissiereductie kan naast in de installatie voor mestbewerking ook door andere factoren zoals de meetopzet veroorzaakt kan zijn. Echter hiervoor is aangetoond dat de gemeten ammoniakemissiereductie niet door systematische verschillen tussen case en controlafdeling veroorzaakt zijn.

Ook kunnen verschillen in de mestsamenstelling tussen de control en case afdeling een deel van de gemeten emissiereductie verklaren. Bij van de Brandhof is geen verschil in mestsamenstelling opgetreden. Toch is bij dit bedrijf een ammoniakemissiereductie van $17 \%$ gemeten.

Mogelijk kan de emissiereductie verklaard worden door louter verdunnen van de mest. Bij van de Beek is èn een duidelijk verschil in droge stof tussen control en case gevonden èn een ammoniakemissiereductie van 35\%. Verdunnen van mest is een op de stopperslijst opgenomen methode voor ammoniakemissiereductie ${ }^{(2)}$. Door verdunnen van de mest kan een ammoniakemissiereductie gerealiseerd worden van $45 \%^{(3)}$. Met de installatie voor mestbewerking worden minieme hoeveelheden vocht aan de mest toegevoegd, te weten $15,3 \mathrm{ml}$ per dag of te wel 0,07 liter per dierplaats per jaar. Volgens de publicatie van Infomil ${ }^{(3)}$ moet minimaal 1000 liter per dierplaats per jaar water aan de mest toegevoegd worden. Bovendien mag het droge stofgehalte maximaal $70 \mathrm{~g} / \mathrm{kg}$ bedragen. Zowel bij van de Beek, als bij van de Brandhof is dit gehalte voor de onbehandelde en behandelde mest aanzienlijk hoger. De gemeten ammoniakemissiereductie kan dus ook niet aan het verdunnen van de mest toegeschreven worden.

Uit de analyseresultaten van mest blijkt dat de installatie de samenstelling van de mest wijzigt. Volgens het beschreven werkingsmechanisme (§2.3) wordt de gasvorming in de mest verminderd, wat in lijn is met de verminderde methaanemissie. Bij van de Beek is stikstof vooral gebonden in $\mathrm{NH}_{3}$ en heeft dit niet geresulteerd in verminderde lachgas emissies. Bij van de Brandhof is de ammoniakemissiereductie kleiner dan bij van de Beek, maar is er wel een grotere lachgasemissiereductie gemeten van $20 \%$. 


\section{Ad 6. Reductie overige gassen}

De resultaten van de methaan en lachgasmetingen staan in $\S 3.5$ en in bijlage E. Hieruit blijkt dat bij Van de Beek er gemiddeld over de metingen geen verschil in methaan- en lachgasemissies gemeten wordt door toepassing van de installatie voor mestbewerking. Wel kan opgemerkt worden dat bij 4 van de 6 metingen een methaanemissiereductie door de installatie voor mestverwerking gemeten is. Meting 4, waarbij een grote negatieve methaanemissiereductie door de installatie voor mestbewerking is aangetoond, kan statistisch als uitbijter beschouwd worden. Als deze meting buiten beschouwing gelaten wordt, wordt bij van de Beek een methaanemissiereductie van $16 \%$ gemeten.

Bij Van de Brandhof wordt in de stal met de installatie voor mestbewerking een $35 \%$ lagere methaanemissie en een $20 \%$ lagere lachgasemissie gemeten ten opzichte van de referentieafdeling.

Gemiddeld is er bij beide bedrijven een methaanemissiereductie gemeten van $20 \%$ en een lachgasemissiereductie van $8 \%$.

\section{Ad 7. Aanbevelingen}

Uit het voorgaande volgt dat de gemeten emissiereductie van ammoniak, methaan en lachgas toegeschreven moet worden aan de invloed van de installatie voor mestbewerking. De wijze waarop de installatie voor mestbewerking de samenstelling van de mest verandert en welke factoren hierop van invloed zijn, is op dit moment niet bekend. Nader onderzoek kan dit aantonen, bijvoorbeeld door de massabalans van de behandelde mest in kaart te brengen. Dit kan door het uitvoeren van laboratoriumproeven. 


\section{CONCLUSIES}

1. Bij de twee bedrijven zijn 2 metingen in de zomer, 2 in de lente/najaar en 2 in de winter uitgevoerd. De metingen op de twee locaties zijn voor wat betreft de groeifase redelijk verdeeld over de seizoenen uitgevoerd. Er is sprake van een klein acceptabel verschil in gewicht van de dieren in de case en control afdeling van de beide bedrijven. Hiermee is voldaan aan de organisatorische vereisten voor de uitvoering van het onderzoek.

2. Uit de metingen is een duidelijk verschil naar voren gekomen in de ammoniakemissiereductie bij de beide bedrijven. Bij Van de Beek in Putten is een gemiddelde reductie gemeten van $35 \%$ en bij Van de Brandhof in Ede van $17 \%$. Hiermee is een gemiddelde ammoniakemissiereductie van $26 \%$ aangetoond.

3. Het verschil in de gemeten ammoniakemissiereductie bij van de Beek en van de Brandhof kan worden toegeschreven aan de invloed van het nieuwe beton op de mestsamenstelling bij van de Brandhof in Ede. Bovendien is bij van de Brandhof sprake van een lage ammoniak emissiefactor. Hierdoor heeft het verlagen van de putemissie door de installatie van mestbewerking nog slechts een beperkt effect op de totale emissie van de stal.

4. In het onderzoek zijn diverse factoren die van invloed kunnen zijn op de gemeten ammoniakemissiereductie onderzocht. Dit betreft:

- $\quad$ het verschil in gewicht van de dieren tussen de case en control afdeling;

- $\quad$ het verschil in ventilatiedebiet van de case en control afdeling;

- $\quad$ het verschil in de samenstelling van de mest tussen de case en control afdeling;

- $\quad$ het verdunnen van de mest door de installatie voor bewerking.

Uit de analyse van de meetresultaten blijkt dat de gemeten ammoniakemissiereductie niet toegeschreven kan worden aan bovengenoemde factoren.

5. Bij van de Beek wordt een methaanemissiereductie gemeten van $16 \%$. Er wordt geen lachgasemissiereductie gemeten. Bij Van de Brandhof wordt in de stal met de installatie voor mestbewerking een 35\% lagere methaanemissie en een $20 \%$ lagere lachgasemissie gemeten ten opzichte van de referentieafdeling. Gemiddeld is er bij beide bedrijven een methaanemissiereductie gemeten van $20 \%$ en een lachgasemissiereductie van $8 \%$. 
6. De gemeten emissiereductie van ammoniak, methaan en lachgas moet toegeschreven moet worden aan de invloed van de installatie voor mestbewerking. De wijze waarop de installatie voor mestbewerking de samenstelling van de mest verandert en welke factoren hierop van invloed zijn, is op dit moment niet volledig bekend. Nader onderzoek kan dit aantonen, bijvoorbeeld door de massabalans van de behandelde mest in kaart te brengen. Dit kan door het uitvoeren van laboratoriumproeven 


\section{LITERATUUR}

1. voedergewassen, Commissie bemesting grasland en. Mestsamenstelling in Adviesbasis Bemesting Grasland en Voedergewassen. 2012. Rapport 1.

2. Ministerie van Infrastructuur en milieu. Lijst alternatieve maatregelen voor stoppende bedrijven, Actieplan ammoniak veehouderij. 19 december 2012.

3. Infomil. Ammoniak en agrarische bedrijven - Tabel met maatregelen. Infomil. [Online] [Citaat van: ] http://www.infomil.nl/onderwerpen/landbouwtuinbouw/ammoniak-en/actieplan-ammoniak/stoppersmaatregelen/tabel-maatregelen/. AAV 2012.07. 


\section{BIJLAGEN}




\section{A. Mestbehandelingsinstallatie}

\section{Werkingsprincipe}

De installatie voor mestbewerking reduceert de ammoniakuitstoot door dagelijks een hoeveelheid natuurlijk mineralenmengsel te sprayen over de drijfmest. Door dit dagelijks te herhalen verandert het proces in de mest. Hierdoor stopt de gasvorming in de mest en wordt de emissie van onder andere ammoniak sterk gereduceerd. De stikstof blijft in de mest en komt later beschikbaar voor de planten.

Het natuurlijk mineralenmengsel bestaat uit natuurlijke mineralen, minerale zuurstof en een aantal specifieke bacteriën.

De natuurlijke mineralenmengsel heeft een sterke remming op de methanogene fase (gasproductie). Door het stoppen van het anaerobe proces in de mest en het opstarten van een aerobe proces vindt er een reductie van de ammoniakemissie.

De technische uitvoering van het systeem

Aansturing

De aansturing verzorgd het tijdstip van toediening en de duur van de toediening van de AgriMestMix. Hiervoor worden zowel de magneetventielen als de volumepomp aangestuurd.

Magneetventielen

Op basis van een elektrisch signaal wordt het ventiel geopend en gesloten. Per magneetventiel wordt één afdeling aangesloten.

Volume pomp

De volumepomp zorgt voor toevoegen van de AgriMestMix aan de luchtstroom. De volumepomp is van $0 \%$ tot $100 \%$ instelbaar.

Luchtcompressor

De luchtcompressor levert een continue druk op het systeem van minimaal 3 bar.

Voorraadvat AgriMestMix

De AgriMestMix wordt opgezogen uit het voorraadvat.

Sproeinippels

De sproeinippels voor en achter in de stal dienen eenzijdig te worden uigevoerd. De sproeinippel in het midden van de afdeling wordt tweezijdig uitgevoerd.

Controle

Wekelijks dient het scherm van de aansturing te worden gecontroleerd op foutmelding. Jaarlijks wordt de installatie gecontroleerd op de werking door de leverancier/deskundige partij.

Onderhoud

Het systeem is vrij van onderhoud. 


\section{Registratie}

De registratie wordt in overleg met het ministerie bepaalt.

Voor het systeem is het aflezen van de gebruikte hoeveelheid AgriMestMix relevant. Dit kan door:

a. Het registreren van de hoeveelheid door de volumemeter.

b. Het registreren van de hoeveelheid dat wordt opgezogen uit het volumevat.

c. Het certificeren van de mest door de leverancier/deskundige partij. Hiervoor wordt regelmatig door de leverancier/deskundige partij de installatie gecontroleerd en de voorraad AgriMestMix wordt aangevuld. In deze werkwijze wordt tevens de mest gecertificeerd en als speciale mest aangeboden op de markt. Uit proeven blijkt dat de behandelde mest gunstig is voor het bodemleven, een betere benutting geeft van de stikstof en een betere ontwikkeling van het wortelstelsel. Dit laatste geeft een hoger organisch stof gehalte in de grond.

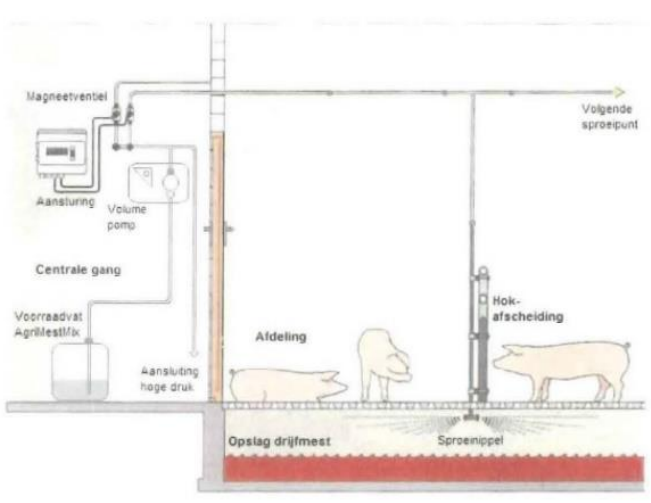




blaut

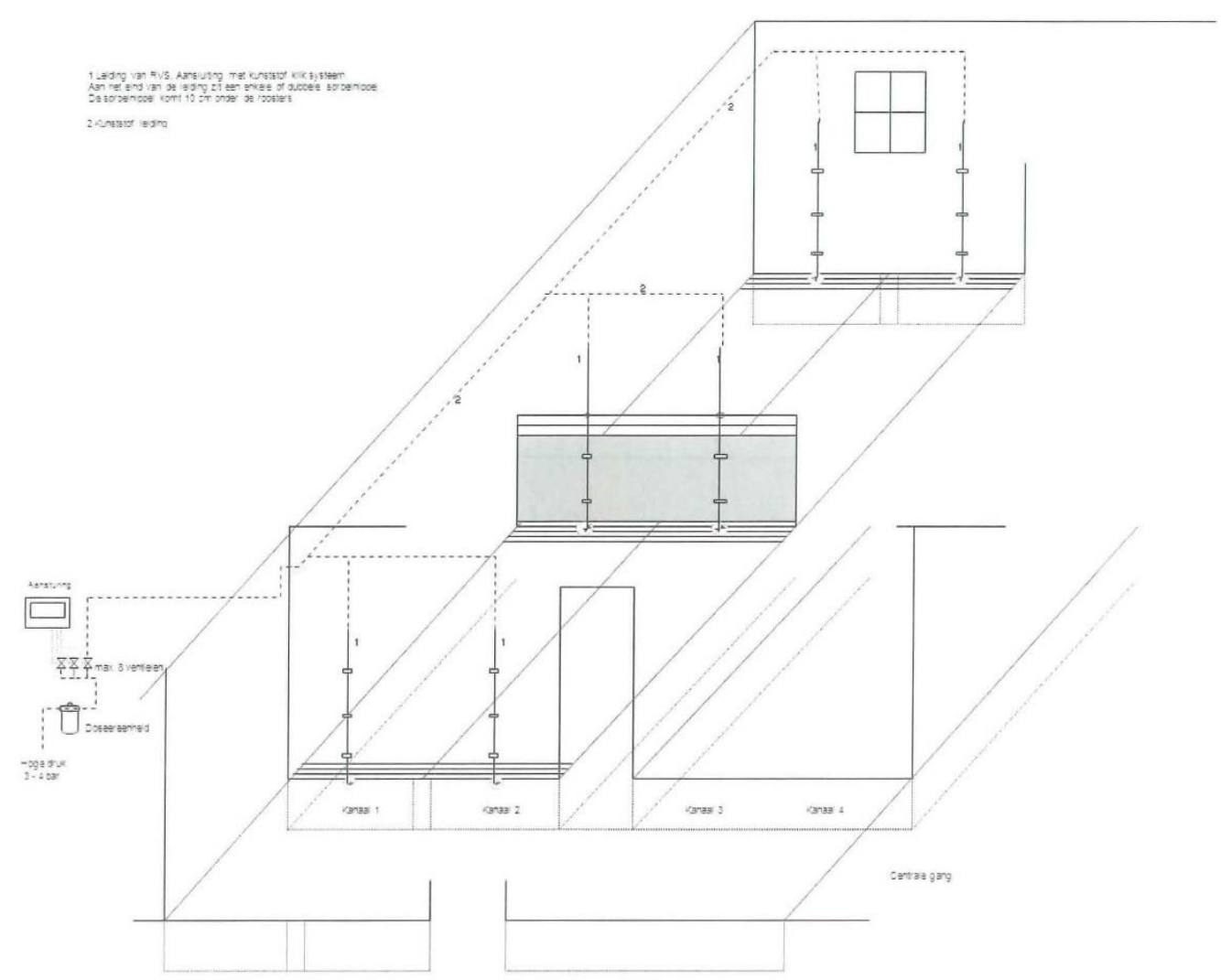


Installatie voor mestbewerking op het bedrijf van Van de Beek in Putten.

\section{Proefopstelling}

In onderstaande schema is een overzicht gegeven van de stal van Van de Beek in Putten

\begin{tabular}{|l|l|l|l|l|}
\hline Lokaal 1 & Lokaal 2 & Lokaal 3 & Lokaal 4 & Lokaal 5 \\
& & & & \\
\hline & & & & \\
\hline
\end{tabular}

In de afdeling 5 is de installatie voor mestbewerking geïnstalleerd. De afdelingen 3 en 5 worden met elkaar vergeleken.

Per afdeling worden er 80 varkens gehouden. Bij aankomst in de stal wegen de varkens ongeveer $40 \mathrm{~kg}$. Bij het verlaten van de stal wegen de varkens naar schatting $110 \mathrm{~kg}$. In een afdeling worden 4 sprayventielen aangebracht, op elke roostervloer twee. Aan de muurzijde bij de ingang wordt een sprayventiel geplaatst die in één richting sproeit. Op de derde hokafscheiding wordt een sprayventiel geplaatst die in twee richtingen sproeit.

Vanaf 27 juni is dagelijks $77 \mathrm{ml}$ ( 1 deel AgriMestMix en 4 delen water) gedoseerd.

Op 17 augustus 2011 is overgeschakeld van het toedienen van verdunde AgriMestMix naar onverdunde AgriMestMix. De dosering bedroeg 15,3 ml AgriMestMix per dag.

Op de meetdagen is door Buro Blauw gecontroleerd of de installatie voor mestbewerking in bedrijf was. 
Installatie voor mestbewerking op het bedrijf van Van den Brandhof in Ede. Proefopstelling

In onderstaande schema is een overzicht gegeven van de stal van Van de Brandhof in Ede

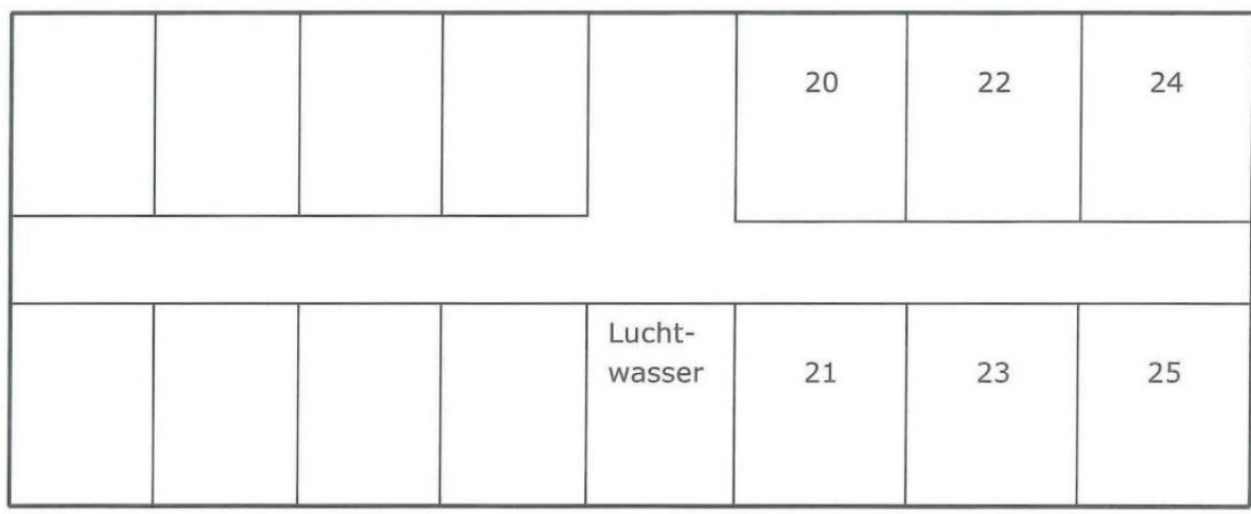

In de afdelingen 21 en 20 is de installatie voor mestbewerking geïnstalleerd. De afdelingen 21 en 23 worden met elkaar vergeleken.

Per afdeling worden er 96 varkens gehouden. Bij aankomst in de stal wegen de varkens ongeveer $25 \mathrm{~kg}$. Bij het verlaten van de stal wegen de varkens naar schatting $110 \mathrm{~kg}$. In een afdeling worden 4 sprayventielen aangebracht, op elke roostervloer twee. Aan de muurzijde bij de ingang wordt een sprayventiel geplaatst die in één richting sproeit. Op de derde hokafscheiding wordt een sprayventiel geplaatst die in twee richtingen sproeit.

Vanaf 11 juni is dagelijks $80 \mathrm{ml}$ ( 1 deel AgriMestMix en 4 delen water) gedoseerd.

Op 17 augustus 2011 is overgeschakeld van het toedienen van verdunde AgriMestMix naar onverdunde AgriMestMix. De dosering bedroeg 15,3 ml AgriMestMix per dag.

Op de meetdagen is door Buro Blauw gecontroleerd of de installatie voor mestbewerking in bedrijf was. 


\section{B. Meetmethode debiet volgens ISO 10780}

De debietmetingen van de geforceerde emissies zijn uitgevoerd zoals beschreven in de norm ISO 10780 (1994), Stationary source emissions -Measurement of velocity and volume flowrate of gas streams in ducts. De luchtsnelheid is met een radanenometer of pitotbuis gemeten, de temperatuur met een K-type voeler, het drukverschil met een druksonde, vocht met een capacitieve sensor of met de natte bol/droge bol methode en de druk met een precisie barometer. Tabel C.1 geeft een overzicht van de toegepaste debietmeetapparatuur.

Tabel B.1. Meetapparatuur voor de metingen van de afgaskarakteristieken

\begin{tabular}{|c|c|c|c|c|}
\hline Grootheid & Dimensie & Apparatuur & Meetbereik & Nauwkeurigheid \\
\hline Luchtsnelheid & $\mathrm{hPa}$ & $\begin{array}{l}\text { L- of S-type pitotbuis } \\
\text { met druksensor }\end{array}$ & $0-10 \mathrm{hPa}$ & $\pm 0,03 \mathrm{hPa}$ \\
\hline Vochtgehalte & $\begin{array}{l}\% \\
\mathrm{~g} / \mathrm{m}^{3}\end{array}$ & $\begin{array}{l}\text { Capacitieve sensor } \\
\text { K-type thermokoppels }\end{array}$ & $\begin{array}{l}0 \ldots 100 \% \text { RV } \\
-40 \ldots 260^{\circ} \mathrm{C}\end{array}$ & $\begin{array}{l} \pm 2 \% R V(2 \ldots 98 \% R V) \\
\pm 1,1^{\circ} \mathrm{C}\end{array}$ \\
\hline Temperatuur & ${ }^{\circ} \mathrm{C}$ & K-type thermokoppel & $-40 \ldots 260^{\circ} \mathrm{C}$ & $\pm 1,1^{\circ} \mathrm{C}$ \\
\hline Drukverschil & $\mathrm{hPa}$ & Druksonde & $\pm 100 \mathrm{hPa}$ & $\pm 0,1 \mathrm{hPa}(0 \ldots 20 \mathrm{hPa})$ \\
\hline Absolute druk & $\mathrm{hPa}$ & Precisie barometer & $908 \ldots 1062 \mathrm{hPa}$ & $\pm 0,8 \mathrm{hPa}$ \\
\hline
\end{tabular}

Volgens de norm ISO 10780 is een meetonzekerheid van minder dan 5\% haalbaar indien aan alle randvoorwaarden in de norm wordt voldaan. In de praktijk is vaak geen sprake van de meest ideale omstandigheden waardoor een meetonzekerheid van $10 \%-20 \%$ gehanteerd wordt.

Om na te gaan of het meetvlak voldoet aan de randvoorwaarden die in ISO 10780 voor debietmetingen worden gesteld zijn voorafgaand aan de metingen temperatuur- en luchtsnelheidsmetingen uitgevoerd. De criteria voor ongestoorde profielen is in tabel C.2 gegeven.

Tabel B.2 Criteria meetvlakbeoordeling debietmetingen

\begin{tabular}{ll}
\hline Parameter & Criterium \\
\hline Gassnelheid & $>3 \mathrm{~m} / \mathrm{s}$ \\
Richting gasstroom van kanaal & $<15^{\circ}$ t.o.v. lengteas van kanaal \\
Fluctuaties drukverschil per meetpunt & $\leq 24 \mathrm{~Pa}$ \\
Dynamische en statische druk & $\mathrm{P}>0,5 \mathrm{~mm} \mathrm{H} \mathrm{O}(\mathrm{P}>5 \mathrm{~Pa})$ \\
Verdeling gassnelheid & Afwijking gem. snelheid per as $<5 \%$ van totale gemiddelde \\
Richting & Geen "negatieve" luchtsnelheden \\
Temperatuurafwijkingen & $\leq 5 \%$ van het gemiddelde \\
\hline
\end{tabular}




\section{Meetmethode ammoniak}

De ammoniakconcentratie (berekend als ammoniak) in de afgassen is gemeten conform NEN 2826, 1999: Luchtkwaliteit. Uitworp door stationaire puntbronnen. Monsterneming en bepaling van het gehalte aan gasvormig ammoniak.

Voor de monstername van ammoniak wordt bij warme afgassen gebruik gemaakt van een verwarmde monsternameleiding. De monsterlucht is isokinetisch aangezogen en eerst door een filterhouder geleid om vervolgens via de monsternameleiding naar drie gekoelde wasflessen gevuld met $0,05 \mathrm{M} \mathrm{H}_{2} \mathrm{SO}_{4}$ en door een droogkolom gevuld met silicagel geleid te worden. Een monsternamepomp zoog de bemonsterde lucht met ongeveer 1 liter per minuut door de wasflessen en de droogkolom. Hierna is de lucht door een gekalibreerde droge gasmeter geleid. Figuur C.1 toont een schematisch overzicht van de meetopstelling. De monsternameleidingen zijn na afloop van de metingen gespoeld met $0,05 \mathrm{M} \mathrm{H}_{2} \mathrm{SO}_{4}$ en het spoelmonster is bij bij de eerste wasfles gevoegd.

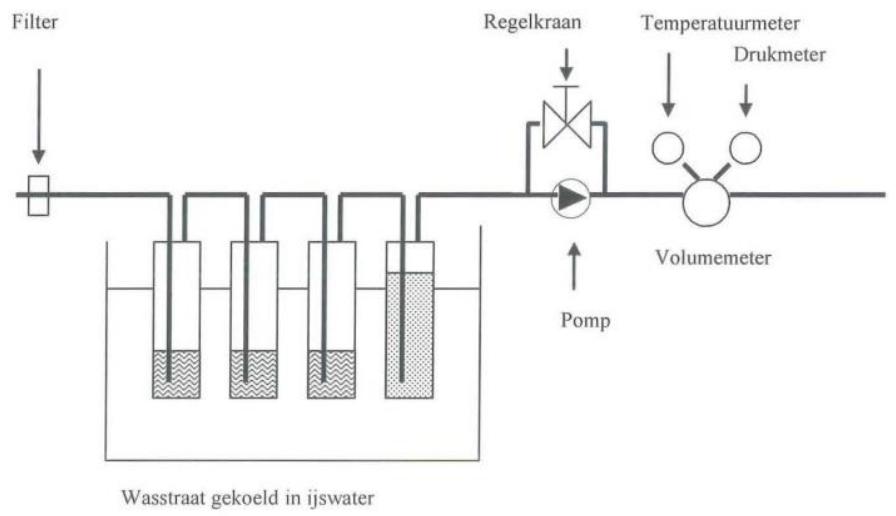

Figuur C.1 Schematisch overzicht van de meetopstelling voor ammoniak

$\mathrm{Na}$ afloop van de meting wordt de inhoud van de eerste en de tweede wasfles bij elkaar gevoegd. De inhoud van de derde wasfles wordt apart aan het laboratorium ter analyse aangeboden. Indien de concentratie in dit monster hoger is dan $5 \%$ dan de concentratie in de eerste twee wasflessen, dan is er sprake van doorslag en wordt de meting afgekeurd.

De impingervloeistoffen zijn door het geaccrediteerde laboratorium Al-West in Deventer geanalyseerd. 


\section{D.1 Technische gegevens Van de Beek in Putten}

In Figuur D.1.1 is een foto van de meetsituatie bij Van de Beek in Putten gegeven.

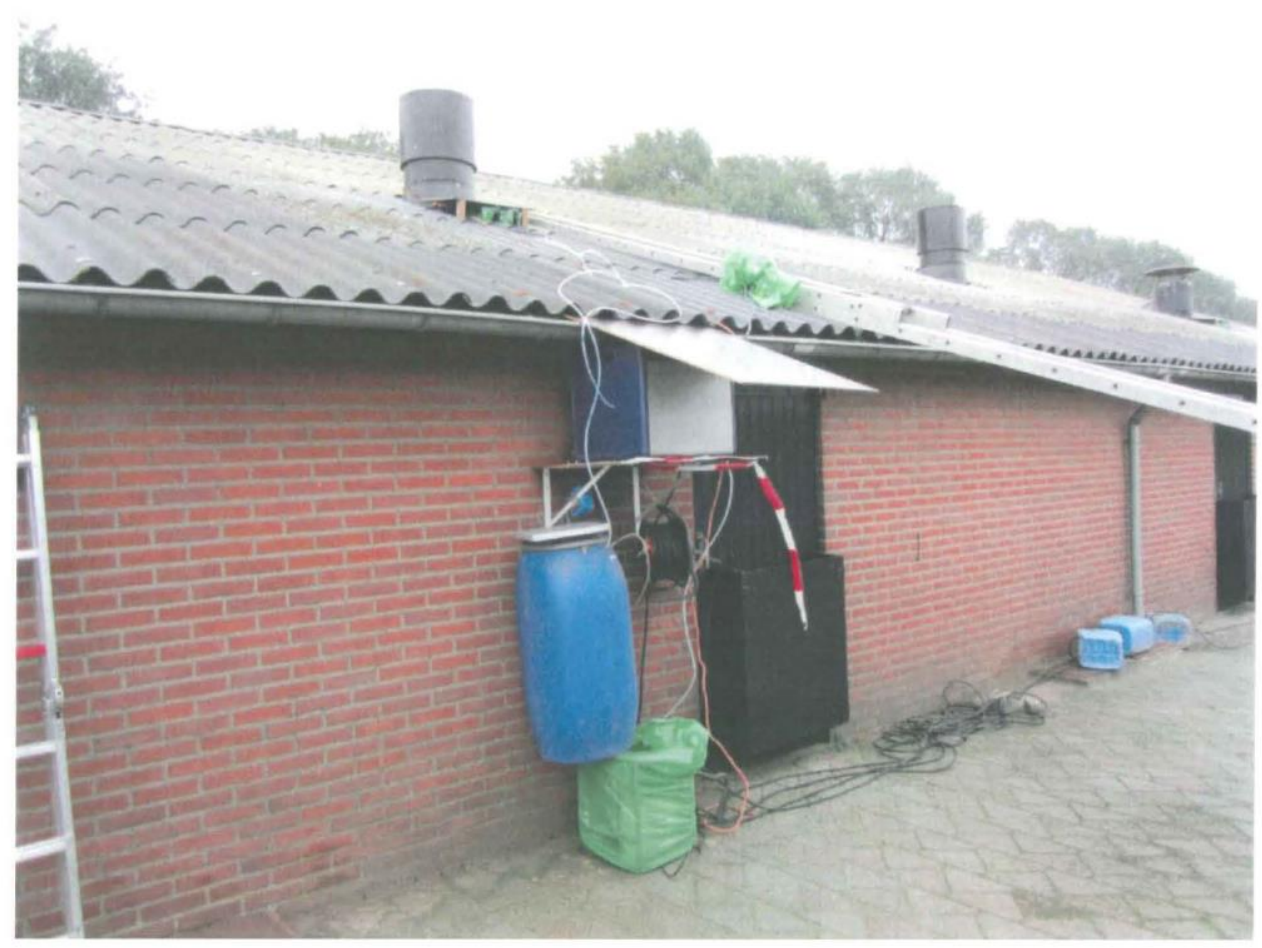

Figuur D.1.1. Foto van de stal van Van de Beek

\section{Afmetingen stal}

De stal van $v d$ Beek bestaat uit vijf afdelingen. Iedere afdeling is 6,55 meter breed en 12,60 meter diep. Iedere afdeling bestaat uit $2 * 4$ hokken met een middenpad. De totale stal is 35 meter lang en 14,7 meter breed.

\section{Mestoppervlak in de mestkelder}

Het emitterende mestoppervlak is $35 \mathrm{~m} 2$ per afdeling.

De kelder onder de ligplaatsen is afgesloten.

\section{Ventilatie instelling}

Op basis van een temperatuur thermostaat per afdeling.

\section{Temperatuurinstelling}

De temperatuur is ingesteld op 22 graden Celsius op de thermostaat.

\section{Verwarming}

Ventilatie systeem zuigt warme lucht tussen dakplaten en isolatieplaten uit. 
Voersysteem en voersoorten

Droogvoerbakken die worden dagelijks met de voerkar gevuld

Voersoorten zijn groei- en afmestbrok

Voeraanbod, voertijden

Eenmaal per dag krijgen de dieren een dagdosering.

Drinksysteem

1 Drinknippel in elke droogvoerbak

\section{Lichtregiem}

De lichten branden 9,5 uur per dag.

In tabel D.1.1 zijn de technische gegevens van lokaal 3 gegeven.

\begin{tabular}{|c|c|c|c|c|}
\hline Gemeten ronde & 1 & 2 & 3 & 4 \\
\hline Datum opleg & $8-4-2011$ & $8-7-2011$ & $14-9-2011$ & $21-12-2011$ \\
\hline Aantal varkens in & 80 & 80 & 80 & 80 \\
\hline Lengte productieronde (dagen) & 139 & 130 & 139 & 113 \\
\hline Aflevergewicht (kg) & 113 & 114 & 121 & 117 \\
\hline Aantal uitgevallen dieren & 4 & 1 & 1 & 0 \\
\hline Bezettingsgraad ( $/ \mathrm{m}^{2} /$ dier $)$ & 0,9 & 0,9 & 0,9 & 0,9 \\
\hline Aantal dieren per hok & 10 & 10 & 10 & 10 \\
\hline Groei per dag (g) & 779 & 788 & 749 & 796 \\
\hline Samenstelling voer g RE/EW & $160 / 105$ & $160 / 105$ & $160 / 105$ & $160 / 105$ \\
\hline Uitval (\%) & 5 & 1,25 & 1,25 & $0 \%$ \\
\hline Water/voer-verhouding & $?$ & $?$ & $?$ & $?$ \\
\hline Totale hoeveelheid verstrekt voer & 23.962 & 26.185 & 29.257 & 19.851 \\
\hline Totale hoeveelheid verbruikt water & Ad lib & Ad lib & Ad lib & Ad lib \\
\hline $\begin{array}{l}\text { veterinaire behandelingen op } \\
\text { koppelniveau }\end{array}$ & ОтС & OTC & ОтС & OTC \\
\hline $\begin{array}{l}\text { schatting van de hoeveelheid } \\
\text { verbruikt schoonmaakwater } \\
\text { inclusief het restant in de mestput. }\end{array}$ & ? & $?$ & $?$ & $?$ \\
\hline $\begin{array}{l}\text { tijdstippen van verwijderen van } \\
\text { (drijf)mest uit de mestput }\end{array}$ & Niet & Niet & Niet & Niet \\
\hline
\end{tabular}




\section{blauw}

In tabel D.1.2 zijn de technische gegevens van lokaal 5 gegeven.

\begin{tabular}{|c|c|c|c|c|}
\hline Gemeten ronde & 1 & 2 & 3 & 4 \\
\hline Datum opleg & $22-4-2011$ & 29-6-2011 & $29-9-2011$ & $7-12-2011$ \\
\hline Aantal varkens in & 80 & 80 & 80 & 80 \\
\hline Lengte productieronde (dagen) & 125 & 139 & 124 & 118 \\
\hline Aflevergewicht (kg) & 111 & 117 & 120 & 113 \\
\hline Aantal uitgevallen dieren & 2 & 1 & 1 & 0 \\
\hline Bezettingsgraad (/m²/dier) & 0,9 & 0,9 & 0,9 & 0,9 \\
\hline Aantal dieren per hok & 10 & 10 & 10 & 10 \\
\hline Groei per dag (g) & 797 & 792 & 777 & 726 \\
\hline Samenstelling voer g RE/EW & $160 / 105$ & $160 / 105$ & $160 / 105$ & $160 / 105$ \\
\hline Uitval (\%) & 2,5 & 1,25 & 1,25 & 0 \\
\hline Water/voer-verhouding & $?$ & $?$ & $?$ & $?$ \\
\hline $\begin{array}{l}\text { Totale hoeveelheid verstrekt } \\
\text { voer }\end{array}$ & 24.721 & 27.391 & 24.235 & 19.079 \\
\hline $\begin{array}{l}\text { Totale hoeveelheid verbruikt } \\
\text { water }\end{array}$ & Ad lib & Ad lib. & Ad lib. & Ad lib. \\
\hline $\begin{array}{l}\text { veterinaire behandelingen op } \\
\text { koppelniveau }\end{array}$ & OTC & OTC & OTC & OTC \\
\hline $\begin{array}{l}\text { schatting van de hoeveelheid } \\
\text { verbruikt schoonmaakwater } \\
\text { inclusief het restant in de } \\
\text { mestput. }\end{array}$ & $?$ & $?$ & $?$ & $?$ \\
\hline $\begin{array}{l}\text { tijdstippen van verwijderen van } \\
\text { (drijf)mest uit de mestput }\end{array}$ & Niet & Niet & Niet & Niet \\
\hline
\end{tabular}




\section{D.2 Technische gegevens Van de Brandhof in Ede}

\section{Afmetingen}

Afmeting afdeling 9 bij 10 meter, 4 hokken aan beide zijden met een voergang in het midden hokken 2.5 breed en 4 meter diep.

\section{Mestoppervlak}

Rooster oppervlak $2 * 10$ maal 2 is 40 vierkante meter per afdeling is tevens mestoppervlak

\section{Ventilatie}

Temperatuur minimum, maximum

$\begin{array}{llcr} & & \text { Ventilatie } & \text { ventilatie } \\ \text { Dag } 0 & 25 & 5 \% & 35 \% \\ \text { Dag } 7 & 24 & 5 \% & 50 \% \\ \text { Dag } 50 & 23 & 5 \% & 75 \% \\ \text { Dag } 99 & 21 & 5 \% & 85 \%\end{array}$

\section{Vloerverwarming}

Gaat aan zodra de temperatuur onder de instelling komt

\section{Voersysteem}

Driemaal daags wordt brij gevoerd

\section{Voersoort}

2 fasen. Start- en vleesvarkens voer

\section{Voeraanbod}

De varkens worden om 6.00 uur 13.00 uur en 18.00 uur beperkt gevoerd volgens voerschema

\section{Drinksysteem}

Drinknippel

\section{Licht}

Via de ramen 40 lux. Natuurlijke verlichting. 
In tabel D.2.1 zijn de technische gegevens van lokaal 23 gegeven.

\begin{tabular}{|l|c|c|}
\hline Gemeten ronde & 1 & $\mathbf{2}$ \\
\hline Datum opleg & $5-7-2011$ & $2-11-2011$ \\
\hline Aantal varkens in & 96 & 96 \\
\hline Lengte productieronde (dagen) & 118 & 124 \\
\hline Aflevergewicht (gesl. kg) & 92,06 & 92,1 \\
\hline Aantal uitgevallen dieren & 1 & 3 \\
\hline Bezettingsgraad (/m²/dier) & 0,8 & 0,8 \\
\hline Aantal dieren per hok & 12 & 12 \\
\hline Groei per dag (g) & 830 & 777 \\
\hline Samenstelling voer g RE/EW & $170 / 115$ & $170 / 115$ \\
\hline $\begin{array}{l}\text { Uitval (\%) } \\
\text { Water/voer-verhouding }\end{array}$ & 1 & 3 \\
\hline $\begin{array}{l}\text { Totale hoeveelheid verstrekt } \\
\text { voer }\end{array}$ & 21.601 & 22.684 \\
\hline $\begin{array}{l}\text { Totale hoeveelheid verbruikt } \\
\text { water }\end{array}$ & 57.027 & 59.886 \\
\hline $\begin{array}{l}\text { veterinaire behandelingen op } \\
\text { koppelniveau }\end{array}$ & - & - \\
\hline $\begin{array}{l}\text { schatting van de hoeveelheid } \\
\text { inclusief het restant in de } \\
\text { mestput. }\end{array}$ & 0 & 0 \\
\hline $\begin{array}{l}\text { tijdstippen van verwijderen van } \\
\text { (drif)mest uit de mestput }\end{array}$ & Aug. & April \\
\hline
\end{tabular}


In tabel D.2.2 zijn de technische gegevens van lokaal 21 gegeven.

\begin{tabular}{|l|c|c|}
\hline Gemeten ronde & $\mathbf{1}$ & $\mathbf{2}$ \\
\hline Datum opleg & $13-7-2011$ & $9-11-2011$ \\
\hline Aantal varkens in & 96 & 96 \\
\hline Lengte productieronde (dagen) & 118 & 112 \\
\hline Aflevergewicht (gesl. kg) & 93,7 & 89,1 \\
\hline Aantal uitgevallen dieren & 1 & 4 \\
\hline Bezettingsgraad (/m 2 /dier) & 0,8 & 0,8 \\
\hline Aantal dieren per hok & 12 & 12 \\
\hline Groei per dag (g) & 834 & 813 \\
\hline Samenstelling voer g RE/EW & $170 / 115$ & $170 / 115$ \\
\hline $\begin{array}{l}\text { Uitval (\%) } \\
\text { Water/voer-verhouding }\end{array}$ & 1 & 4 \\
\hline $\begin{array}{l}\text { Totale hoeveelheid verstrekt } \\
\text { voer }\end{array}$ & 21.659 & 20.735 \\
\hline $\begin{array}{l}\text { Totale hoeveelheid verbruikt } \\
\text { water }\end{array}$ & 57.180 & 54.740 \\
\hline $\begin{array}{l}\text { veterinaire behandelingen op } \\
\text { koppelniveau } \\
\text { schatting van de hoeveelheid } \\
\text { inclusief hehoonmaakwater } \\
\text { mestput. }\end{array}$ & - & - \\
\hline $\begin{array}{l}\text { tijdstippen van verwijderen van } \\
\text { (drijf)mest uit de mestput }\end{array}$ & Aug. & Febr \\
\hline
\end{tabular}




\section{blauw}

\section{E.1 Gedetailleerde gegevens metingen Van de Beek Putten}

\begin{tabular}{|c|c|c|c|c|c|c|c|}
\hline Meting & & $\begin{array}{c}1 \\
\text { Onbehandeld } \\
\text { Lokaal } 3\end{array}$ & $\begin{array}{c}1 \\
\text { 8ehandeld } \\
\text { Lokaal } 5\end{array}$ & $\begin{array}{c}2 \\
\text { Onbehandeld } \\
\text { Lokaal } 3\end{array}$ & $\begin{array}{c}2 \\
\text { Behandeld } \\
\text { Lokaal } 5\end{array}$ & $\begin{array}{c}3 \\
\text { Onbehandeld } \\
\text { Lokaal } 3\end{array}$ & $\begin{array}{c}3 \\
\text { Behandeld } \\
\text { Lokaal } 5\end{array}$ \\
\hline \multicolumn{8}{|l|}{ Ammoniak } \\
\hline Concentratie & {$\left[\mathrm{mg} / \mathrm{m}_{0}{ }^{3}\right]$} & 30,7 & 32,7 & 26,7 & 20,1 & 31,9 & 22,5 \\
\hline Debiet & {$\left[m_{0}{ }^{3} /\right.$ uur] } & 2833 & 1876 & 2049 & 1760 & 2251 & 1936 \\
\hline Datum & [dd-mm-ijij] & $26-07-11$ & 26.07 .11 & $12-09-11$ & $12-09-11$ & $17-10-11$ & $17 \cdot 10-11$ \\
\hline Deel van cyclus & {$[-]$} & 4 & 4 & 2 & 2 & 5 & 5 \\
\hline Emissie & [g/uur] & 87 & 61 & 55 & 35 & 72 & 43 \\
\hline Aantal dieren & {$[-]$} & 80 & 80 & 80 & 80 & so & 80 \\
\hline Emissie per dier & [ $g /$ dier/uur] & 1,09 & 0,77 & 0,68 & 0,44 & 0,90 & 0,54 \\
\hline Aantal dagen per jaar & {$[-]$} & 329 & 329 & 329 & 329 & 329 & 329 \\
\hline Emissie per dier per jaar & [g/dierrjaar] & 8597 & 6051 & 5398 & 3483 & 7087 & 4290 \\
\hline Emissie per dier per jaar & [kg/dier/jaar] & 8,6 & 6,1 & 5,4 & 3,5 & 7,1 & 4,3 \\
\hline Rendement & [\%] & & $30 \%$ & & $35 \%$ & & $39 \%$ \\
\hline Temperatuur afgas & {$\left[{ }^{\circ} \mathrm{C}\right]$} & 26,4 & 28,7 & 27,6 & 27,6 & 25,9 & 25,4 \\
\hline Relatieve luchtvochtigheid afgas & {$[\%]$} & 65,3 & 71,2 & 69,4 & 67,6 & 73,4 & 64,0 \\
\hline Droge stof & [g DS/kg] & 123 & 95 & 133 & 98 & 123 & 70 \\
\hline Ruwe as & [g RAS/kg] & 31 & 20 & 34 & 23 & 33 & 21 \\
\hline Organische stof & {$[\mathrm{g} O S / \mathrm{kg}]$} & 92 & 75 & 99 & 75 & 90 & 49 \\
\hline Stikstof & [g N/kg] & 8,7 & 7,6 & 9,1 & 7,4 & 9.0 & 7,0 \\
\hline CN ratio & {$[H$} & 5 & 4 & 5 & 5 & 4 & 3 \\
\hline Stikstof-ammoniak & {$\left[\mathrm{g} \mathrm{N}-\mathrm{NH}_{2} / \mathrm{kg}\right]$} & 4,9 & 4,2 & 4,6 & 4,1 & 5,1 & 4,7 \\
\hline Stikstof-organisch & [g N-org/kg] & 3,8 & 3,4 & 4,5 & 3,3 & 3,9 & 2,3 \\
\hline Fosfor & [g P/kg] & 2,9 & 2,3 & 3,3 & 2,1 & 3,0 & 1,7 \\
\hline Fosfaat & {$\left[\mathrm{g} \mathrm{P}_{2} \mathrm{O}_{z} / \mathrm{kg}\right]$} & 6,6 & 5,4 & 7,6 & 4,7 & 6,9 & 3,9 \\
\hline Kalium & [g K/kg] & 6,0 & 4,7 & 6,2 & 4,8 & 6,1 & 4,6 \\
\hline Kali & [ $\mathrm{g} \mathrm{K}_{2} \mathrm{O} / \mathrm{kg}$ ] & 7,2 & 5,7 & 7,5 & 5,8 & 7,3 & 5,5 \\
\hline Magnesium & [g Mg/kg] & 1,1 & 1,3 & 2,0 & 1,3 & 2,0 & 1,1 \\
\hline Magnesia & [g MgO/kg] & 1,8 & 2,2 & 3,3 & 2,2 & 3,3 & 1,8 \\
\hline Natrium & [g Na/kg] & 0,7 & 0,9 & 1,4 & 1,1 & 1,4 & 1,2 \\
\hline Natron & [g Na $\left.{ }_{2} \mathrm{O} / \mathrm{kg}\right]$ & 0,9 & 1,2 & 1,9 & 1,5 & 1,9 & 1,6 \\
\hline$\rho H$ & & 8,0 & 7,8 & 8,0 & 7,8 & 8,1 & 7,8 \\
\hline Methaan & [ppm] & 103 & 177 & 147 & 166 & 155 & 141 \\
\hline Concentratie & {$\left[\mathrm{mg} / \mathrm{mo}^{3}\right]$} & 74 & 127 & 105 & 119 & 111 & 101 \\
\hline Debiet & [ $m_{0}^{3} /$ uur] & 2833 & 1876 & 2049 & 1760 & 2251 & 1936 \\
\hline Emissie & [g/uur] & 209 & 238 & 216 & 209 & 250 & 195 \\
\hline Aantal dieren & {$[H$} & so & 80 & 80 & 80 & 80 & 80 \\
\hline Emissie per dier & [g/dierfiuur] & 3 & 3 & 3 & 3 & 3 & 2 \\
\hline Aantal dagen per jaar & {$[-]$} & 329 & 329 & 329 & 329 & 329 & 329 \\
\hline Emissie per dier per jaar & [g/dietfjaar] & 20624 & 23471 & 21290 & 20649 & 24660 & 19293 \\
\hline Emissie per dier per jaar & [kg/dier/jaar] & 21 & 23 & 21 & 21 & 25 & 19 \\
\hline Lachgas & [ppm] & 0,311 & 0,448 & 0,345 & 0,408 & 0,482 & 0,540 \\
\hline Concentratie & {$\left[\mathrm{mg} / \mathrm{m}^{3}\right]$} & 0,61 & 0,88 & 0,68 & 0,80 & 0,95 & 1,06 \\
\hline Debiet & {$\left[\mathrm{m}_{0}{ }^{3 / u v r}\right]$} & 2833 & 1876 & 2049 & 1760 & 2251 & 1936 \\
\hline Emissie & [g/uur] & 1,73 & 1,65 & 1,39 & 1,41 & 2,13 & 2,05 \\
\hline Aantal dieren & {$[-]$} & 80 & 80 & so & 80 & so & so \\
\hline Emissie per dier & [g/dier/uur] & 0,0216 & 0,0206 & 0,0174 & 0,0176 & 0,0266 & 0,0257 \\
\hline Aantal dagen per jaar & H] & 329 & 329 & 329 & 329 & 329 & 329 \\
\hline Emissie per dier per jaar & [g/dier/jaar] & 170,86 & 163,00 & 137,10 & 139,25 & 210,40 & 202,73 \\
\hline Emissie per dier per jaar & [kg/dier/jaar] & 0,171 & 0,163 & 0,137 & 0,139 & 0,210 & 0,203 \\
\hline
\end{tabular}




\section{E.1 Vervolg gedetailleerde meetgegevens Van de Beek Putten}

\begin{tabular}{|c|c|c|c|c|c|c|c|}
\hline \multirow[t]{2}{*}{ Meting } & & $\begin{array}{c}4 \\
\text { Onbehandeld }\end{array}$ & $\begin{array}{c}4 \\
\text { Behandeid }\end{array}$ & $\begin{array}{c}5 \\
\text { Onbehandeld }\end{array}$ & $\begin{array}{c}5 \\
\text { Behandeld }\end{array}$ & $\begin{array}{c}6 \\
\text { Onbehandelc }\end{array}$ & $\begin{array}{c}6 \\
\text { Behandeld }\end{array}$ \\
\hline & & Lokaal 3 & Lokaal 5 & Lokaal 3 & Lokaal 5 & Lokaal 3 & Lokaal 5 \\
\hline \multicolumn{8}{|l|}{ Ammoniak } \\
\hline Concentratie & {$\left[\mathrm{mg} / \mathrm{m}_{0}{ }^{3}\right]$} & 26,3 & 22,2 & 34,6 & 26,4 & 21,0 & 13,9 \\
\hline Debiet & {$\left[\mathrm{m}_{0}{ }^{3 / \mathrm{uur}}\right]$} & 2184 & 1937 & 1792 & 1768 & 2275 & 2139 \\
\hline Datum & [dd-mm-jij] & 23-11-11 & $23-11-11$ & 3-01-12 & $3-01-12$ & $5-03-12$ & 5-03-12 \\
\hline Deel van cyclus & {$[-]$} & 1 & 1 & 5 & 5 & 3 & 3 \\
\hline Emissie & [g/uur] & 58 & 43 & 62 & 47 & 48 & 30 \\
\hline Aantal dieren & {$[-]$} & 80 & 80 & 80 & 80 & 80 & 80 \\
\hline Emissie per dier & [g/dier/uur] & 0,72 & 0,54 & 0.77 & 0,58 & 0,60 & 0,37 \\
\hline Aantal dagen per jaar & {$[H]$} & 329 & 329 & 329 & 329 & 329 & 329 \\
\hline Emissie per dier per jaar & [g/dier/jaar] & 5678 & 4245 & 6113 & 4598 & 4713 & 2940 \\
\hline Emissie per dier per jaar & [kg/dier/jaar] & 5,7 & 4,2 & 6,1 & 4,6 & 4,7 & 2,9 \\
\hline Rendement & {$[\%]$} & & $25 \%$ & & $25 \%$ & & $38 \%$ \\
\hline Temperatuur afgas & {$\left[{ }^{\circ} \mathrm{C}\right]$} & 25,0 & 24,0 & 24,1 & 23,9 & 21,5 & 21,2 \\
\hline Relatieve luchtrochtigheid afgas & {$[\%]$} & 65,6 & 62,5 & 79,0 & 78,4 & 57,2 & 53,6 \\
\hline Droge stof & [g DS/kg] & 112 & 111 & 116 & 105 & 119 & 86 \\
\hline Ruwe as & [g RAS/kg] & 30 & 27 & 31 & 25 & 30 & 22 \\
\hline Organische stof & [g OS $/ \mathrm{kg}]$ & 82 & 84 & 85 & 80 & 89 & 64 \\
\hline Stikstof & [g N/kg] & 8,7 & 8,2 & 9,3 & 8,2 & 9,5 & 7,1 \\
\hline$C / N$ ratio & {$[H]$} & 4 & 5 & 4 & 4 & 4 & 4 \\
\hline Stikstof-ammoniak & [g N-NH$/ / \mathrm{kg}]$ & 5,0 & 4,5 & 5,4 & 4,5 & 5,4 & 4,2 \\
\hline Stikstof-organisch & [g N-org/kg] & 3,7 & 3,7 & 3,9 & 3,7 & 4,1 & 2,9 \\
\hline Fosfor & [g P/kg] & 2,8 & 2,7 & 2,9 & 2,6 & 2,9 & 2,2 \\
\hline Fosfaat & {$\left[g \mathrm{P}_{2} \mathrm{O}_{5} / \mathrm{kg}\right]$} & 6,3 & 6,1 & 6,5 & 5,9 & 6,6 & 5,1 \\
\hline Kalium & [g K/kg] & 5,7 & 4,7 & 5,6 & 4,4 & 5,6 & 3,8 \\
\hline Kali & {$[\mathrm{g} \mathrm{K} 2 \mathrm{O} / \mathrm{kg}]$} & 6,9 & 5,7 & 6,7 & 5,3 & 6,7 & 4,6 \\
\hline Magnesium & [g Mg/kg] & 1,8 & 1,8 & 1,9 & 1,7 & 1,8 & 1,5 \\
\hline Magnesia & {$[\mathrm{g} \mathrm{MgO} / \mathrm{kg}]$} & 3,0 & 3,0 & 3,2 & 2,8 & 3,0 & 2,5 \\
\hline Natrium & [g Na/kg] & 1,3 & 1,1 & 1,4 & 1,1 & 1,3 & 0,9 \\
\hline Natron & {$\left[\mathrm{g} \mathrm{Na}_{2} \mathrm{O} / \mathrm{kg}\right]$} & 1,8 & 1,5 & 1,9 & 1,5 & 1,8 & 1,2 \\
\hline pH & & 8,0 & 7,8 & 7,8 & 7,7 & 7,9 & 7,7 \\
\hline Methaan & [ppm] & 92 & 134 & 189 & 144 & 146 & 126 \\
\hline Concentratie & {$\left[\mathrm{mg} / \mathrm{m}_{0}{ }^{3}\right]$} & 66 & 96 & 135 & 103 & 105 & 90 \\
\hline Debiet & {$\left[\mathrm{m}_{0}{ }^{3} / \mathrm{uur}\right]$} & 2184 & 1937 & 1792 & 1768 & 2275 & 2139 \\
\hline Emissie & [g/uur] & 144 & 186 & 242 & 182 & 238 & 193 \\
\hline Aantal dieren & {$[-]$} & 80 & 80 & 80 & 80 & 80 & 80 \\
\hline Emissie per dier & [g/dier/uur] & 2 & 2 & 3 & 2 & 3 & 2 \\
\hline Aantal dagen per jaar & {$[H$} & 329 & 329 & 329 & 329 & 329 & 329 \\
\hline Emissie per dier per jaar & [g/dier/jaar] & 14203 & 18341 & 23932 & 17992 & 23479 & 19049 \\
\hline Emissie per dier per jaar & [kg/dier/jaar] & 14 & 18 & 24 & 18 & 23 & 19 \\
\hline Lachgas & [ppm] & 0,419 & 0,534 & 0,459 & 0,516 & 0,360 & 0,398 \\
\hline Concentratie & {$\left[\mathrm{mg} / \mathrm{m}_{0}{ }^{3}\right]$} & 0,82 & 1,05 & 0,90 & 1,01 & 0,71 & 0,78 \\
\hline Debiet & {$\left[\mathrm{m}_{0}{ }^{3} / \mathrm{uur}\right]$} & 2184 & 1937 & 1792 & 1768 & 2275 & 2139 \\
\hline Emissie & [g/uur] & 1,80 & 2,03 & 1,62 & 1,79 & 1,61 & 1,67 \\
\hline Aantal dieren & {$[\cdot]$} & 80 & 80 & 80 & 80 & 80 & 80 \\
\hline Emissie per dier & [g/dier/uur] & 0,0225 & 0,0254 & 0,0202 & 0,0224 & 0,0201 & 0,0209 \\
\hline Aantal dagen per jaar & $\mathrm{H}$ & 329 & 329 & 329 & 329 & 329 & 329 \\
\hline Emissie per dier per jaar & [g/dier/jaar] & 177,48 & 200,54 & 159,47 & 176,89 & 158,85 & 165,09 \\
\hline Emissie per dier per jaar & [kg/dier/jaar] & 0,177 & 0,201 & 0,159 & 0,177 & 0,159 & 0,165 \\
\hline
\end{tabular}




\section{blauw}

\section{E.2 Gedetailleerde meetgegevens Van de Brandhof Ede}

\begin{tabular}{|c|c|c|c|c|c|c|c|}
\hline Meting & [dd-mm-jij] & $\begin{array}{c}1 \\
\text { Onbehandeld } \\
\text { Lokaal } 23 \\
27-07-11 \\
\end{array}$ & $\begin{array}{c}1 \\
\text { Behandeld } \\
\text { Lokaal } 21 \\
27-07-11 \\
\end{array}$ & $\begin{array}{c}2 \\
\text { Onbehandeld } \\
\text { Lokaal } 23 \\
14-09-11 \\
\end{array}$ & \begin{tabular}{c|}
2 \\
Behandeld \\
Lokaal 21 \\
$14-09-11$ \\
\end{tabular} & $\begin{array}{c}3 \\
\text { Onbehandeld } \\
\text { Lokaal } 23 \\
13-10-11 \\
\end{array}$ & $\begin{array}{c}3 \\
\text { Behandeld } \\
\text { Lokaal } 21 \\
13-10-11 \\
\end{array}$ \\
\hline \multicolumn{8}{|l|}{ Ammoniak } \\
\hline Concentratie & {$\left[\mathrm{mg} / \mathrm{m}_{0}{ }^{3}\right]$} & 11,0 & 10,6 & 8,9 & 8,9 & 14,2 & 11,9 \\
\hline Debiet & {$\left[\mathrm{m}_{0}{ }^{3} / \mathrm{uur}\right]$} & 1571 & 1191 & 2639 & 2063 & 2587 & 2308 \\
\hline Emissie & [giuur] & 17,3 & 12,7 & 23,4 & 18,4 & 36,7 & 27,5 \\
\hline Aantal dieren & {$[-]$} & 96 & 96 & 96 & 96 & 96 & 96 \\
\hline Emissie per dier & [g/dier/uur] & 0,18 & 0,13 & 0,24 & 0,19 & 0,38 & 0,29 \\
\hline Aantal dagen per jaar & {$[-]$} & 329 & 329 & 329 & 329 & 329 & 329 \\
\hline Emissie per dier per jaar & [g/dier/jaar] & 1420 & 1043 & 1925 & 1512 & 3020 & 2266 \\
\hline Emissie per dier per jaar & [kg/dier/jaar] & 1,4 & 1,0 & 1,9 & 1,5 & 3,0 & 2,3 \\
\hline Rendement & [\%] & & $27 \%$ & & $21 \%$ & & $25 \%$ \\
\hline Temperatuur afgas & {$\left[{ }^{\circ} \mathrm{C}\right]$} & 27,1 & 27,4 & 25,4 & 25,9 & 24,0 & 23,4 \\
\hline Relatieve luchtvochtigheid afgas & {$[\%]$} & 72,6 & 76,4 & 61,4 & 62,6 & 67,6 & 65,1 \\
\hline Droge stof & [g DS/kg] & 125 & 139 & 136 & 130 & 130 & 124 \\
\hline Ruwe as & [g RAS/kg] & 26 & 30 & 26 & 26 & 26 & 26 \\
\hline Organische stof & [g OS/kg] & 99 & 109 & 110 & 104 & 104 & 98 \\
\hline Stikstof & [g N/kg] & 8,1 & 9,0 & 8,8 & 8,5 & 8,6 & 9,6 \\
\hline C/N ratio & {$[-]$} & 5 & 5 & 6 & 6 & 5 & 5 \\
\hline Stikstof-ammoniak & [g N-NH$/ / k g]$ & 4,7 & 5,0 & 4,6 & 4,3 & 4,8 & 4,9 \\
\hline Stikstof-organisch & [g N-org/kg] & 3,4 & 4,0 & 4,2 & 4,2 & 3,8 & 3,7 \\
\hline Fosfor & [g P/kg] & 2,0 & 2,2 & 1,9 & 2,1 & 2,1 & 2,1 \\
\hline Fosfaat & {$\left[\mathrm{g} \mathrm{P}_{2} \mathrm{O}_{3} / \mathrm{kg}\right]$} & 4,7 & 5,0 & 4,4 & 4,8 & 4,9 & 4,8 \\
\hline Kalium & [g K/kg] & 4,8 & 5,1 & 5,0 & 5,1 & 5,1 & 5,5 \\
\hline Kali & [g K $\mathrm{K}_{2} \mathrm{O} / \mathrm{kg}$ ] & 5,8 & 6,1 & 6,0 & 6,1 & 6,1 & 6,6 \\
\hline Magnesium & [g Mg/kg] & 1,4 & 1,4 & 1,2 & 1,5 & 1,5 & 1,5 \\
\hline Magnesia & [g MgO/kg] & 2,3 & 2,3 & 2,0 & 2,5 & 2,5 & 2,5 \\
\hline Natrium & [g Na/kg] & 1,0 & 0,9 & 1,2 & 1,1 & 1,2 & 1,2 \\
\hline Natron & [g Na $\left.\mathrm{Na}_{2} \mathrm{O} / \mathrm{kg}\right]$ & 1,3 & 1,2 & 1,6 & 1,5 & 1,6 & 1,6 \\
\hline $\mathrm{pH}$ & & 7,5 & 7,2 & 7,3 & 7,4 & 7,1 & 7,2 \\
\hline Methaan & {$[p p m]$} & 17,8 & 14.8 & 15,9 & 15,3 & 21,5 & 24,8 \\
\hline Concentratie & {$\left[\mathrm{mg} / \mathrm{mo}^{3}\right]$} & 13 & 11 & 11 & 11 & 15 & 18 \\
\hline Debiet & {$\left[\mathrm{m}_{0}{ }^{3 / \text { tuur }]}\right.$} & 1571 & 1191 & 2639 & 2063 & 2587 & 2308 \\
\hline Emissie & [g/uur] & 20 & 13 & 30 & 23 & 40 & 41 \\
\hline Aantal dieren & {$[-]$} & 96 & 96 & 96 & 96 & 96 & 96 \\
\hline Emissie per dier & [g/dier/uur] & 0 & 0 & 0 & 0 & 0 & 0 \\
\hline Aantal dagen per jaar & {$[-]$} & 329 & 329 & 329 & 329 & 329 & 329 \\
\hline Emissie per dier per jaar & [g/dier/jaar] & 1647 & 1038 & 2471 & 1859 & 3276 & 3371 \\
\hline Emissie per dier per jaar & [kg/dier/jaar] & 1,6 & 1,0 & 2,5 & 1,9 & 3,3 & 3,4 \\
\hline Lachgas & [ppm] & 0,393 & 0,400 & 0,354 & 0,346 & 0,459 & 0,474 \\
\hline Concentratie & {$\left[\mathrm{mg} / \mathrm{mo}_{0}{ }^{3}\right]$} & 0,77 & 0,79 & 0,70 & 0,68 & 0,90 & 0,93 \\
\hline Debiet & {$\left[m_{0}{ }^{3} /\right.$ uur] } & 1571 & 1191 & 2639 & 2063 & 2587 & 2308 \\
\hline Emissie & [g/uur] & 1,21 & 0,94 & 1,84 & 1,40 & 2,33 & 2,15 \\
\hline Aantal dieren & 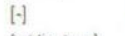 & 96 & 96 & 96 & 96 & 96 & 96 \\
\hline Emissie per dier & [g/dier/uur] & 0,0126 & 0,0097 & 0,0191 & 0,0146 & 0,0243 & 0,0224 \\
\hline Aantal dagen per jaar & {$[\cdot]$} & 329 & 329 & 329 & 329 & 329 & 329 \\
\hline Emissie per dier per jaar & [g/dier/jaar] & 99,79 & 76,96 & 150,97 & 115,33 & 191,92 & 176,78 \\
\hline Emissie per dier per jaar & [kg/dier/jaar] & 0,100 & 0,077 & 0,151 & 0,115 & 0,192 & 0,177 \\
\hline
\end{tabular}




\section{blauw}

\section{E.2 Vervolg gedetailleerde meetgegevens Van de Brandhof Ede}

\begin{tabular}{|c|c|c|c|c|c|c|c|}
\hline Meting & [dd-mm-jjj] & \begin{tabular}{|c|}
4 \\
Onbehandeld \\
Lokaal 23 \\
$7-12-11$ \\
\end{tabular} & $\begin{array}{c}4 \\
\text { Behandeld } \\
\text { Lokaal } 21 \\
7-12-11 \\
\end{array}$ & $\begin{array}{c}5 \\
\text { Onbehandeld } \\
\text { Lokaal } 23 \\
5-01-12 \\
\end{array}$ & $\begin{array}{c}5 \\
\begin{array}{c}\text { Behandeld } \\
\text { Lokaal } 21 \\
5-01-12 \\
\end{array} \\
\end{array}$ & \begin{tabular}{|c}
6 \\
Onbehandeld \\
Lokaal 23 \\
$10-02-12$ \\
\end{tabular} & $\begin{array}{c}6 \\
\text { Behandeld } \\
\text { Lokaal } 21 \\
10-02-12 \\
\end{array}$ \\
\hline Ammoniak & & & & & & & \\
\hline Concentratie & {$\left[\mathrm{mg} / \mathrm{m}_{0}{ }^{3}\right]$} & 10,9 & 14,5 & 9,3 & 11,4 & 20,9 & 20,2 \\
\hline Debiet & {$\left[m_{0}{ }^{3} /\right.$ uur] } & 1257 & 875 & 1791 & 1322 & 1200 & 1097 \\
\hline Emissie & [g/uur] & 13,7 & 12,7 & 16,7 & 15,1 & 25,0 & 22,2 \\
\hline Aantal dieren & {$[-]$} & 96 & 96 & 96 & 96 & 96 & 96 \\
\hline Emissie per dier & [g/dier/uur] & 0,14 & 0,13 & 0,17 & 0,16 & 0,26 & 0,23 \\
\hline Aantal dagen per jaar & {$[-]$} & 329 & 329 & 329 & 329 & 329 & 329 \\
\hline Emissie per dier per jaar & [g/dier/jaar] & 1124 & 1043 & 1375 & 1240 & 2059 & 1826 \\
\hline Emissie per dier per jaar & [kg/dier/jaar] & 1,1 & 1,0 & 1,4 & 1,2 & 2,1 & 1,8 \\
\hline Rendement & {$[\%]$} & & $7 \%$ & & $10 \%$ & & $11 \%$ \\
\hline Temperatuur afgas & {$\left[{ }^{\circ} \mathrm{C}\right]$} & 24,4 & 24,8 & 24,4 & 23,7 & 21,6 & 21,4 \\
\hline Relatieve luchtvochtigheid afgas & [\%] & 70,3 & 63,1 & 70,4 & 55,6 & 57,8 & 57,7 \\
\hline Droge stof & {$[g D S / \mathrm{kg}]$} & 144 & 127 & 129 & 130 & 125 & 141 \\
\hline Ruwe as & [g RAS $/ \mathrm{kg}]$ & 30 & 26 & 27 & 30 & 27 & 28 \\
\hline Organische stof & {$[g$ OS $/ \mathrm{kg}]$} & 114 & 101 & 102 & 100 & 98 & 113 \\
\hline Stikstof & [g N/kg] & 8,7 & 8,9 & 8,6 & 8,7 & 9,0 & 9,0 \\
\hline C/N ratio & {$[-]$} & 6 & 5 & 5 & 5 & 5 & 6 \\
\hline Stikstof-ammoniak & {$\left[\mathrm{g} \mathrm{N}-\mathrm{NH}_{3} / \mathrm{kg}\right]$} & 4,8 & 5,1 & 4,8 & 4,9 & 4,9 & 4,9 \\
\hline Stikstof-organisch & [g N-org $/ \mathrm{kg}]$ & 3,9 & 3,8 & 3,8 & 3,8 & 4,1 & 4,1 \\
\hline Fosfor & [g P/kg] & 2,4 & 2,2 & 2,3 & 2,3 & 2,4 & 2,5 \\
\hline Fosfaat & {$\left[g \mathrm{P}_{2} \mathrm{O}_{2} / \mathrm{kg}\right]$} & 5,5 & 5,1 & 5,2 & 5,3 & 5,6 & 5,7 \\
\hline Kalium & {$[\mathrm{g} K / \mathrm{kg}]$} & 5,3 & 5,5 & 5,5 & 5,5 & 6,0 & 6,1 \\
\hline Kali & {$\left[\mathrm{g} \mathrm{K}{ }_{2} \mathrm{O} / \mathrm{kg}\right]$} & 6,4 & 6,6 & 6,6 & 6,6 & 7,2 & 7,3 \\
\hline Magnesium & [g Mg/kg] & 1,6 & 1,4 & 1,5 & 1,6 & 1,3 & 1,4 \\
\hline Magnesia & [ $\mathrm{g} \mathrm{MgO} / \mathrm{kg}$ ] & 2,7 & 2,3 & 2,5 & 2,7 & 2,2 & 2,3 \\
\hline Natrium & [g Na/kg] & 1,3 & 1,2 & 1,4 & 1,3 & 1,2 & 1,1 \\
\hline Natron & [g Na $\mathrm{Na}_{2} \mathrm{O} / \mathrm{kg}$ ] & 1,8 & 1,6 & 1,9 & 1,8 & 1,6 & 1,5 \\
\hline $\mathrm{pH}$ & & 7,3 & 7,4 & 7,2 & 7,4 & 7,3 & 7,2 \\
\hline Methaan & [ppm] & 52,6 & 37,0 & 31,1 & 20,9 & 60,6 & 32,0 \\
\hline Concentratie & {$\left[\mathrm{mg} / \mathrm{mo}_{0}{ }^{3}\right]$} & 38 & 26 & 22 & 15 & 43 & 23 \\
\hline Debiet & {$\left[\mathrm{m}_{0}{ }^{3} / \mathrm{uur}\right]$} & 1257 & 875 & 1791 & 1322 & 1200 & 1097 \\
\hline Emissie & [g/uur] & 47 & 23 & 40 & 20 & 52 & 25 \\
\hline Aantal dieren & {$[-]$} & 96 & 96 & 96 & 96 & 96 & 96 \\
\hline Emissie per dier & [g/dier/uur] & 0 & 0 & 0 & 0 & 1 & 0 \\
\hline Aantal dagen per jaar & {$[-]$} & 329 & 329 & 329 & 329 & 329 & 329 \\
\hline Emissie per dier per jaar & [g/dier/jaar] & 3893 & 1908 & 3280 & 1628 & 4283 & 2068 \\
\hline Emissie per dier per jaar & [kg/dier/jaar] & 3,9 & 1,9 & 3,3 & 1,6 & 4,3 & 2,1 \\
\hline Lachgas & {$[\mathrm{ppm}]$} & 0,536 & 0,480 & 0,507 & 0,532 & 0,416 & 0,424 \\
\hline Concentratie & {$\left[\mathrm{mg} / \mathrm{mo}_{0}{ }^{3}\right]$} & 1,05 & 0,94 & 1,00 & 1,05 & 0,82 & 0,83 \\
\hline Debiet & {$\left[\mathrm{m}_{0}{ }^{3} /\right.$ uur] } & 1257 & 875 & 1791 & 1322 & 1200 & 1097 \\
\hline Emissie & [g/uur] & 1,32 & 0,83 & 1,78 & 1,38 & 0,98 & 0,91 \\
\hline Aantal dieren & {$[\mathrm{H}$} & 96 & 96 & 96 & 96 & 96 & 96 \\
\hline Emissie per dier & [g/dier/uur] & 0,0138 & 0,0086 & 0,0186 & 0,0144 & 0,0102 & 0,0095 \\
\hline Aantal dagen per jaar & {$[-]$} & 329 & 329 & 329 & 329 & 329 & 329 \\
\hline Emissie per dier per jaar & [g/dier/jaar] & 108,86 & 67,90 & 146,71 & 113,68 & 80,67 & 75,18 \\
\hline Emissie per dier per jaar & [kg/dier/jaar] & 0,109 & 0,068 & 0,147 & 0,114 & 0,081 & 0,075 \\
\hline
\end{tabular}




\section{blauw}

\section{F Resultaten ammoniakconcentratiemetingen met een ammoniakmeter}

\begin{tabular}{|c|c|c|c|c|c|c|}
\hline & \multicolumn{2}{|l|}{ 25-aug } & \multicolumn{2}{|l|}{ 15-nov } & \multicolumn{2}{|l|}{ 1-feb } \\
\hline & Afd 3 & .5 & Afd 3 & Afd 5 & Afd 3 & Afd 5 \\
\hline Hok 1 (voor tegen muur) & 66 & 49 & 45 & 16 & 48 & 12 \\
\hline Hok 1 (tegen de muur) & & & 28 & 23 & 39 & 9 \\
\hline Hok 2 (tegen de muur) & 39 & 19 & 18 & 14 & 35 & 17 \\
\hline Hok 3 (tegen de muur) & & & 16 & 7 & 20 & 20 \\
\hline Hok 4 (tegen de muur) & 20 & 8 & 11 & 3 & 15 & 15 \\
\hline Hok 4 (achter tegen de muur) & & & 3 & 2 & 13 & 10 \\
\hline Hok 5 (tegen de voormuur) & 100 & 31 & 51 & 15 & 33 & 22 \\
\hline Hok 5 (tegen de zijmuur) & & & 29 & 16 & 59 & 18 \\
\hline Hok 6 (tegen de muur) & 43 & 17 & 20 & 11 & 34 & 15 \\
\hline Hok 7 (tegen de muur) & & & 18 & 7 & 24 & 11 \\
\hline Hok 8 (tegen de muur) & 13 & 7 & 12 & 4 & 25 & 13 \\
\hline Hok 8 (achter tegen de muur) & & & 8 & 3 & 55 & 9 \\
\hline Middenpad ( 1,5 meter) & 25 & 11. & 17 & 12 & 33 & 11 \\
\hline Gemiddeld & 44 & 20 & 21 & 10 & 33 & 14 \\
\hline Reductie & & $54 \%$ & & $52 \%$ & & $58 \%$ \\
\hline
\end{tabular}

v d Brandhof, Ede

\begin{tabular}{l|r|r}
\cline { 2 - 3 } & \multicolumn{2}{c}{ 1-nov } \\
\cline { 2 - 3 } & Afd 23 & Afd. 21 \\
\hline Hok 1 (voor tegen muur) & 32 & 30 \\
\hline Hok 2 ( tegen de muur) & 31 & 35 \\
\hline Hok 3 (in het midden) & 14 & 12 \\
\hline Hok 4 (achter tegen de muur) & 31 & 30 \\
\hline Hok 5 (tegen de voormuur) & 40 & 39 \\
\hline Hok 6 (tegen de muur) & 33 & 23 \\
\hline Hok 7 (tegen de muur) & 14 & 17 \\
\hline Hok 8 (achter tegen de muur) & 18 & 20 \\
\hline Middenpad (1,5 meter) & 25 & 6 \\
\hline Gemiddeld & 26 & 24 \\
\hline Reductie & & $11 \%$ \\
\hline Middenpad (1,5 meter) & & \\
\hline Reductie middenpad & & $76 \%$ \\
\hline
\end{tabular}




\section{VERANTWOORDING}

\begin{tabular}{|c|c|}
\hline Rapporttitel & $\begin{array}{l}\text { ONDERZOEK AMMONIAKEMISSIEREDUCTIE DOOR INSTALLATIE VAN } \\
\text { MESTBEWERKING }\end{array}$ \\
\hline Subtitel & Case -control metingen bij 2 bedrijven \\
\hline \multirow[t]{2}{*}{ Rapportnummer } & BL2012.5216.02-V04 \\
\hline & Deze versie vervangt eventueel eerder uitgebrachte versies in zijn geheel \\
\hline Documentnaam & BL2012_5216_02_V04.docx \\
\hline Trefwoorden & Ammoniak, emissie, rendement, vleesvarkens, mestbewerkingsinstalltie; RAV \\
\hline Opdrachtgever & Rinagro Piaam \\
\hline Contactpersoon & dhr. A. Dijkstra \\
\hline Uitvoerders & Raoul van Onzenoort, ing. K. van Setten, Peter Gerritzen, ir. J.W. Winters \\
\hline Controleur & Ir. F.B.H. de Bree \\
\hline Datum & 27 maart 2013 \\
\hline
\end{tabular}




\section{blauw \\ onderzoeken advies}

Nude 54-6702 DN Wageningen

telefoon 0317466699 - fax 0317426111

email info@buroblauw.nl - internet www.buroblauw.nl 


\section{Onderzoek naar de invloed van Agri-Mest op mest en gras}

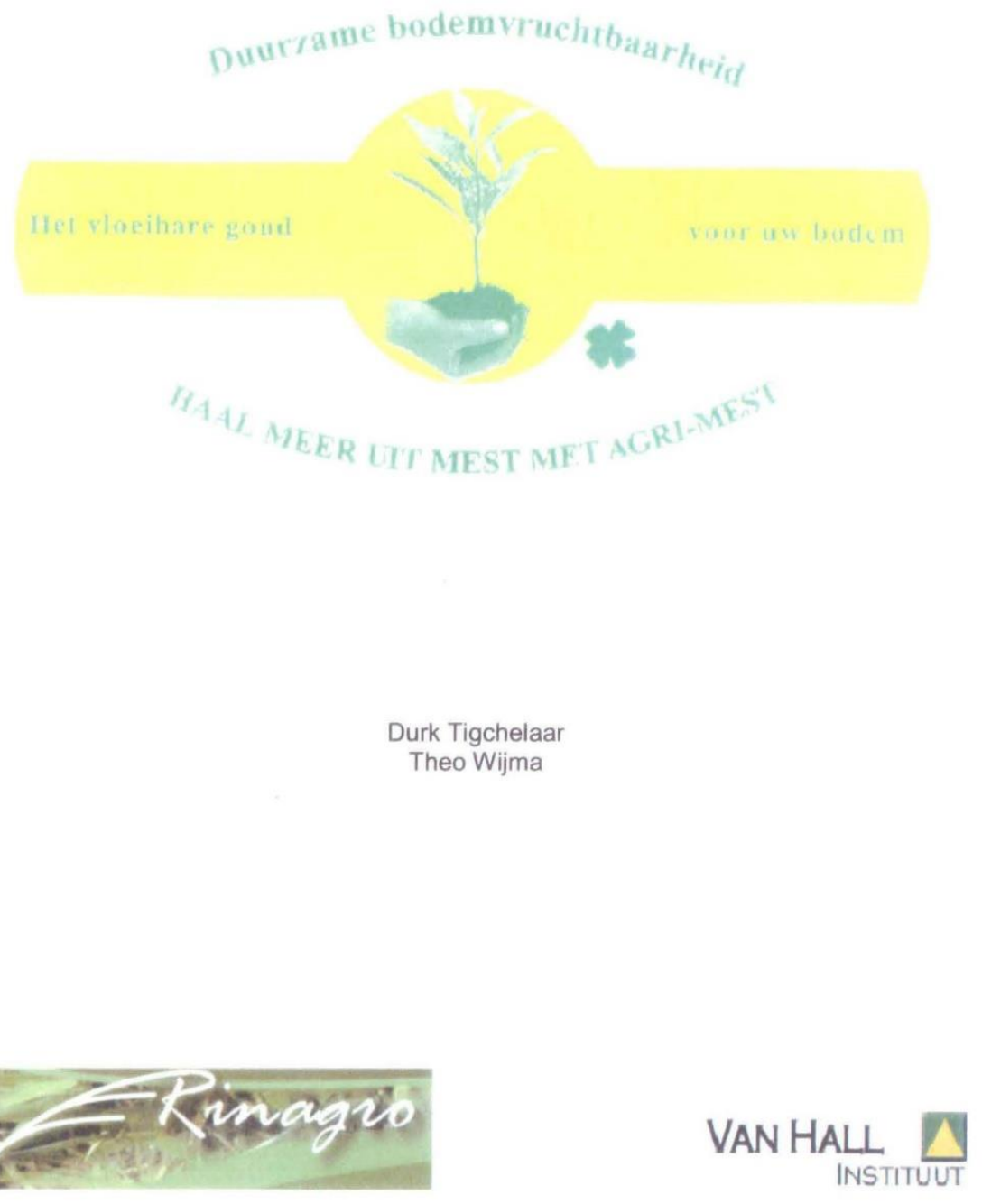


Onderzoek naar de invloed van Agri-Mest op mest en gras

\section{Maart 2005}

Auteurs:

Durk Tigchelaar

Theo Wijma

Onder begeleiding van:

Dhr. H.W. Stegink

Dhr. H. Fokkema

In opdracht van:

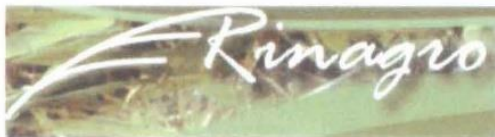

VAN HALL $\triangle$

INSTITUUT 


\section{Samenvatting}

Door de strenger wordende wet- en regelgeving wordt het steeds belangrijker om de beschikbare mest van het bedrijf zelf zo efficiënt mogelijk te benutten.

Een goede bodemvruchtbaarheid en een microbieel milieu waarin omzettingsprocessen worden gestimuleerd worden steeds belangrijker. Deze aspecten leiden tot een kringloop op het bedrijf waarbij elk onderdeel het andere verbetert. Een grond met goede vruchtbaarheid produceert goed en gezond voer, die leidt tot een gezonde koe die goed kan produceren, wat leidt tot goede mest, welke weer tot een goede bodemvruchtbaarheid leidt.

\section{Methodiek.}

Voor het mestonderzoek worden twee vaten opgezet met elk 100 liter mest. Hiervan word een mestanalyse gemaakt. Eèn van de vaten wordt behandeld met Agri-Mest, de ander niet. $\mathrm{De} \mathrm{pH}$ en het droge stof gehalte worden gedurende het onderzoek gevolgd Aan het eind van het onderzoek wordt van beide vaten een mestanalyse gemaakt voor een vergelijking.

Voor de grasproef zijn zes melkveebedrijven geselecteerd, waarvan drie het product Agri-Mest gebruiken. Bij iedere veehouder zijn de proefvelden aangelegd, waarop drijfmest is aangewend. De gebruikte mestsoorten zijn van een bedrijf dat Agri-Mest heeft gebruikt en mest van een bedrijf dag geen Agri-Mest heeft gebruikt. Bij elke veehouder bevinden zich twee veldjes met Agri-Mest en twee veldjes zonder Agri-Mest. ledere week wordt de lichtreflectie, suikerpercentage en droge stof opbrengst gemeten. Net voor de eerste snede zijn de proefvelden gemaaid. Er zijn mengmonsters van het verse gras genomen en geanalyseerd.

\section{Resultaten.}

In de met Agri-Mest behandelde mest blijft 0,3 kg/ton ammoniakale stikstof bespaart ten opzichte van onbehandelde mest. Bij onbehandelde mest ligt de verhouding $\mathrm{N}_{\text {amm }}: \mathrm{N}_{\text {org }}$ op 1,7:3,1. Bij behandelde mest is de verhouding $2: 2,8$. Ook de $\mathrm{C} / \mathrm{N}$ verhouding verandert. Deze is voor onbehandelde mest 7,9 en voor behandelde 7,3 . Duidelijk te merken is ook dat de behandelde mest beter mixt dan onbehandelde mest en de behandelde mest heeft een minder scherpe geur.

PPM-metingen van de grasproef lieten een afnemende waarde zien voor alle proefvelden. De waarden begonnen in het begin van het onderzoek met PPM 80 en eindigden aan het eind van het onderzoek rond een waarde van PPM 45. Voor PPM is er geen verschil tussen behandelde mest en onbehandelde mest Het suikerpercentage is op alle proefvelden bij de Agri-Mest gebruikers lager. Voor de droge stof opbrengsten was het moment van mesttoediening niet op het juiste moment. Agri-Mest zou een extra opbrengst moeten geven, maar dit komt niet uit het onderzoek naar voren.

Op het maaitijdstip zijn monsters genomen van het verse gras. Uit de analyse hiervan blijkt dat er binnen de bedrijven op de verschillende proefvelden geen aannemelijk verschil is in ruw eiwit en suiker. Wanneer de gegevens opgesplitst worden in Agri-Mest gebruikers en niet gebruikers, dan is er wel verschil waar te nemen. Het blijkt dat bij Agri-Mest gebruik over meerdere jaren een hoger ruw eiwit geeft en een lager suikergehalte. Ruw eiwit en suiker zijn aan elkaar gekoppeld. Tevens valt op dat niet Agri-Mest gebruikers een lager of zelfs negatief Onbestendig Eiwit Balans hebben. 


\section{Conclusie.}

Geconcludeerd kan worden dat mest behandeld met Agri-Mest stikstof bevat, welke sneller beschikbaar komt voor de plant. De mest is beter mixbaar doordat de droge stof afneemt

Voor de grasproef kan als conclusie worden gegeven dat Agri-Mest een licht verbeterend effect heeft op de voederwaarde in de vorm van ruw eiwit. 


\section{Conclusie}

\section{Mestproef.}

$\mathrm{Na}$ vergelijking van de analyse van het uitgangsmateriaal met de analyse van de monsters uit de tiende week kan geconcludeerd worden dat de analyse van het uitgangsmateriaal onbetrouwbaar is. Er is maar één monster genomen en zo kunnen de waarden te veel uitersten bevatten. Ditzelfde geldt voor de monsters na afloop van de proefopzet.

Het beeld dat echter met de analyses van de monsters uit de tiende week verkregen is, geeft wel degelijk een trend aan.

Het droge stof percentage neemt met ongeveer 8 procent af, dit resulteert in een betere mixbaarheid. Deze afname kwam zowel uit de eigen meting als de analyses naar voren Zeer duidelijk is dat er een verschuiving van organische stikstof naar ammoniakale stikstof plaatsvindt. De stikstof blijft gemakkelijker in de vloeibare oplossing, waardoor de stikstof sneller beschikbaar komt.

Uit de proefopzet blijkt dat met het gebruik van Agri-Mest 0,3 kg minerale stikstof per kubieke meter. Bij een drijfmestgift van 30 kubieke meter komt er $9 \mathrm{~kg}$ minerale stikstof extra beschikbaar voor de plant. Dit betekent dat bij kunstmestgift van bijvoorbeeld $70 \mathrm{~kg}$ stikstof ongeveer 13 procent minder kan worden gestrooid.

Met deze feiten voldoet Agri-mest aan de verwachtingen vanuit de vraagstelling.

$\mathrm{De} \mathrm{pH}$ van de mest blijft volgens dit onderzoek nagenoeg gelijk. Agri-mest heeft dus op de $\mathrm{pH}$ weinig invloed.

\section{Grasproef.}

\section{Perceelsniveau}

PPM-metingen.

Algemeen gezien is er geen verschil in de PPM-metingen waar te nemen tussen de verschillende proefvelden. Het meerjarige gebruik van Agri-Mest geeft ook geen verschil in de PPM waarden.

Dat bij de PPM waarden "zand niet" en "klei wel" lage meetwaarden hebben kan komen door het feit dat het fosfaat (P-AL) getal in de bodem zeer laag is.

Bij de grondanalyses zijn "Zand niet" (met een waarde van $18 \mathrm{gr} / \mathrm{kg}$ ) en "Klei wel" (met een waarde van $26 \mathrm{gr} / \mathrm{kg}$ ), de gronden met de laagste fosfaatwaarden van de groep. Bi de andere bedrijven zijn de waarden vaak twee maal zo hoog.

\section{Suikermetingen.}

Bij de zelf verrichte metingen voor het suikergehalte in het gras, zijn er binnen de proefvelden op de bedrijven geen verschillen waar genomen. Bij vergelijking van de gegevens over het gebruik en niet gebruik van Agri-mest over meerdere jaren, is er wel verschil.

Agri-mest geeft op de lange termijn een lager suikergehalte in het gewas. Deze conclusie komt niet overeen met de gestelde vraag in bij de onderzoeksvragen. Dat er tussen de proefvelden binnen de bedrijven geen verschil is geconstateerd heeft waarschijnlijk te maken met het feit dat de periode tussen het aanwenden van de mestsoorten en het oogsttijdstip van te korte duur zijn geweest. 
Droge stof opbrengst.

Over de uitkomsten van de droge stof opbrengst kan gezegd worden dat Agri-mest geen invloed heeft gehad in deze proef. De verhoudingen liggen scheef vanwege de grote uitschieters op vooral de zandgronden. Als oorzaak is aan te dragen dat ook hier het moment van mestaanwending te veel uit elkaar ligt en de groeiperiode te kort is geweest.

Ruw eiwit en suiker.

Bij het ruw eiwit valt te vermelden dat de invloed van Agri-mest op het ruw eiwit gelijkblijvend of een verbeterend effect heeft. Geheel volgens verwachting gedraagt het suikergehalte zich tegenovergesteld. Het suiker is hierdoor gelijk of een licht verlagend effect. Bij koppeling van deze uitkomst naar de onderzoeksvragen kan geconcludeerd worden dat Agri-mest geen verbeterend effect heeft op het suikerpercentage.

\section{Lange termijn niveau}

Meerjarig Agri-Mest gebruik

Bij de vergelijking tussen de proefvelden binnen de bedrijven zijn de effecten klein, maar bij vergelijking tussen de Agri-mest gebruikers en de niet Agri-mest gebruikers zijn de verschillen groter.

Uit die verschillen kan opgemaakt worden, dat na vergelijking met de Friese gemiddelden (bron: BLGG, Oosterbeek), de Agri-mest gebruikers gras hebben dat vergelijkbaar is met de gemiddelden. De niet Agri-mest gebruikers hebben een zeer vreemde combinatie van voederwaarden vertoond.

Over het algemeen kan men er van uit gaan dat met het gebruik van Agri-Mest het ruw eiwit in vers gras stijgt met 3 tot 3.5 procent (zie blz. 31). Hiertegenover staat de daling van het suikerpercentage met ongeveer 3 procent bij het gebruik van Agri-Mest. Deze getallen zijn tot stand gekomen door de extreem uitschietende waarden van de bedrijven op zandgrond weg te laten uit de berekening. Het beeld blijft echter hetzelfde, alleen minder extreem.

Opvallend is vooral de lage onbestendig eiwit balans en het lage nitraat $\left(\mathrm{NO}_{3}\right)$ gehalte van $0.3 \mathrm{gr} / \mathrm{kg}$ droge stof t.o.v. $1.2 \mathrm{gr} / \mathrm{kg}$ droge stof van de Agri-mest gebruikers. Na het weglaten van de uitschietende waarden van "zand wel" en "zand niet" zijn de verschillen minder groot, maar het beeld blijft gelijk.

Het hoge nitraat getal in vers gras is tot stand gekomen doordat de opname van stikstof in de vorm van nitraat sneller verloopt in de plant, dan de omzetting naar eiwitten. Op basis van deze wetenschap kan bij Agri-Mest gebruik de kunstmestgift omlaag, zodat de ophoping van stikstof in de vorm van nitraat afneemt. Welke gevolgen dit voor ruw eiwit en suiker zal hebben is niet bekend.

\section{Algemeen.}

Uit de resultaten van de grasproef kan opgemaakt worden dat Agri-Mest een lichte verbetering van de graskwaliteit oplevert. Ten opzichte van de droge stof opbrengst heeft Agrimest geen verbeterend effect. 


\subsection{Analyseresultaten bij meerjarig Agri-Mest gebruik}

Omdat bij beoordeling van de individuele meetwaarden in voorgaande tabellen en figuren geen grote verschillen waarneembaar waren, zijn de meetwaarden nu onderverdeeld in Agri-Mest gebruikers en niet gebruikers. Op deze manier komt het meerjarige gebruik boven.

Tabel 13: Gemiddelde waarden opgedeeld in Agri-Mest gebruikers en niet gebruikers.

\begin{tabular}{|c|c|c|c|c|c|c|}
\hline & & $\mathrm{RE}$ & suiker & $\mathrm{NO}_{3}$ & DVE & OEB \\
\hline & \multirow{3}{*}{$\begin{array}{l}\text { Zand wel, proefveld A } \\
\text { Veen wel, proefveld A } \\
\text { Klei wel, proefveld A }\end{array}$} & 163 & 152 & 1,5 & 96 & 0 \\
\hline & & 168 & 144 & 0,8 & 95 & 6 \\
\hline & & 173 & 146 & 1,2 & 96 & 10 \\
\hline \multirow[t]{4}{*}{1} & Gem. Proefveld A, Agri-Mest gebruikers & 168 & 147 & 1,17 & 96 & 5 \\
\hline & Zand niet, proefveld $A$ & 94 & 299 & 0 & 86 & -61 \\
\hline & Veen niet, proefveld A & 141 & 179 & 0,5 & 91 & -17 \\
\hline & Klei niet, proefveld A & 146 & 169 & 0,6 & 93 & -14 \\
\hline 2 & Gem. Proefveld A, niet Agri-Mest gebruikers & 127 & 216 & 0,37 & 90 & -31 \\
\hline
\end{tabular}

\begin{tabular}{|c|c|c|c|c|c|c|}
\hline & \multirow{3}{*}{$\begin{array}{l}\text { Zand wel, proefveld B } \\
\text { Veen wel, proefveld B } \\
\text { Klei wel, proefveld B }\end{array}$} & 151 & 151 & 0,9 & 90 & -7 \\
\hline & & 169 & 166 & 0,9 & 97 & 5 \\
\hline & & 174 & 134 & 1,3 & 96 & 12 \\
\hline \multirow[t]{4}{*}{3} & Gem. Proefveld B, Agri-Mest gebruikers & 165 & 150 & 1,03 & 94 & 3 \\
\hline & Zand niet, proefveld B & 93 & 305 & 0 & 86 & -62 \\
\hline & Veen niet, proefveld B & 142 & 176 & 0,3 & 91 & -17 \\
\hline & Klei niet, proefveld B & 137 & 185 & 0,4 & 91 & -21 \\
\hline 4 & Gem. Proefveld B, niet Agri-Mest gebruikers & 124 & 222 & 0,23 & 89 & -33 \\
\hline
\end{tabular}

\begin{tabular}{|c|c|c|c|c|c|c|}
\hline & Zand wel, perceel & 179 & 153 & 1,4 & 100 & 12 \\
\hline & Veen wel, perceel & 198 & 169 & 1,3 & 104 & 28 \\
\hline & Klei wel, perceel & 172 & 129 & 1,3 & 95 & 10 \\
\hline \multirow[t]{4}{*}{5} & Gem. perceel, Agri-Mest gebruikers & 183 & 150 & 1,33 & 100 & 17 \\
\hline & Zand niet & 87 & 311 & 0 & 84 & -66 \\
\hline & Veen niet & 121 & 231 & 0 & 92 & -38 \\
\hline & Klei niet & 158 & 133 & 0,9 & 91 & 0 \\
\hline 6 & Gem. perceel, niet Agri-Mest gebruikers & 122 & 225 & 0,3 & 89 & -35 \\
\hline
\end{tabular}

In tabel 13, welke grafisch is uitgebeeld in figuur 10, is duidelijk verschil waarneembaar bij enkele kenmerken. Zo is het ruw eiwit $\pm 40 \mathrm{gr} / \mathrm{kg}$ hoger bij de Agri-Mest gebruikers dan bij de niet gebruikers. Als het ruw eiwit omhoog gaat, gaat het suiker omlaag. Ook het darm verteerbaar eiwit (DVE) en de onbestendig eiwit balans (OEB) is bij de AgriMest gebruikers hoger dan bij de niet-gebruikers.

Opvallend is het hoge nitraat gehalte $\left(\mathrm{NO}_{3}\right)$ in de grasanalyses van de Agri-Mest gebruikers. Het is wel bekend dat als een bodem wordt bemest, lever je een stikstofvoorraad voor de plant, die deels in de vorm van nitraat opgenomen wordt. De plant zet nitraten om in eiwitten voor zijn groei. Als er meer nitraten worden opgenomen dan omgezet, ontstaat er een overmaat aan nitraat in de plant. (Bron: www.bioforum.be) 
Haalbaarheidsonderzoek verbeterde

vergisting door Rinagro producten 


\section{Rapport \\ Haalbaarheidsonderzoek \\ Verbeterde vergisting \\ door \\ Rinagro producten}

Juli 2007

Van Hall Instituut 
Titel

Doel

Projektnummer

Kennisvoucher

Startdatum

Einddatum

Auteurs

Medewerkers

Projectleiding
Haalbaarheidsonderzoek

Verbeterde vergisting door

Rinagro producten.

Initial type testing NEN-EN 12566-3

3202. 57010

SenterNovem nr. G062928

22 mei 2006

19 juni 2007

Dhr ing. G. J. P. Truijen

Dhr drs. G. Bril

Dhr. A. van der Meer

Dhr. H. Reenders

Dhr drs. G. Bril

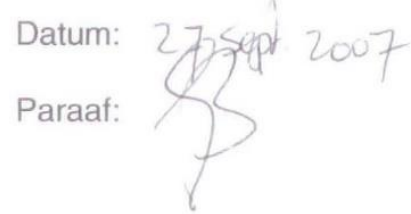




\section{Inhoudsopgave}

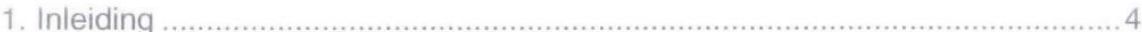

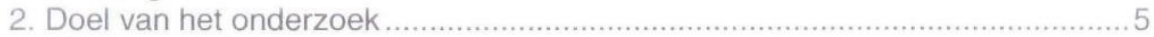

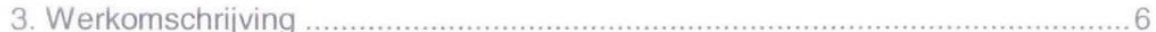

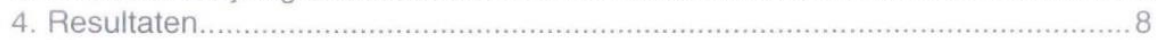

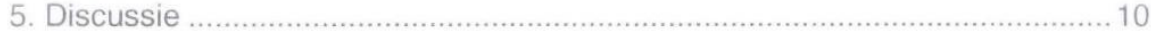

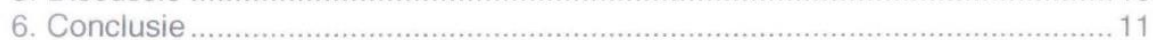

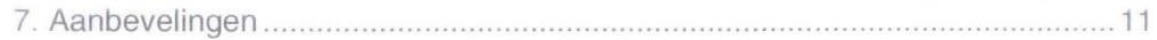




\section{Inleiding}

Rinagro BV heeft al jaren het product Agrimest ${ }^{\circledR}$ in het assortiment.

Agrimest ${ }^{\circledast}$ is een natuurlijk mineralenmengsel dat in drijfmest belangrijke biologische processen op gang brengt.

In de informatie aangeleverd door het bedrijf staat dat het middel wordt toegediend aan de drijfmest. In de mest stimuleert het middel de groei van microorganismen waardoor de mest beter vloeibaar blijft, minder geurt en meer stikstof bevat in de vorm van gebonden ammonium. Dit effect is gunstig voor bodem en gewas.

Rinagro wil graag onderzocht hebben of het gebruik van Agrimest ${ }^{\circledR}$ een gunstig effect heeft op de vergisting van de drijfmest. Naast het mineralenmengsel Agrimest ${ }^{\circledR}$ heeft Rinagro ook het product Agrimest ${ }^{\circledR}$ met $\mathrm{MO}$ (micro-organismen) Deze twee producten zullen in dit onderzoek vergeleken worden met runderdrijfmest zonder toevoeging van de genoemde producten van Rinagro. 


\section{Doel van het onderzoek}

Het toetsen of rundvee drijfmest met Agrimest $^{\circledR}$ en mest met Agrimest $^{\circledR}$ met micro-organismen een betere vergisting geeft dan drijfmest zonder toevoegingen. De verwachting is dat door het toedienen van de producten de volgende verbeteringen kunnen optreden:

verhoogde gasproductie;

versnelling van het opstarten van het vergistingsproces. 


\section{Werkomschrijving}

Voor het toetsen van de mogelijke werking van deze producten wordt gebruik gemaakt van een batchopstelling (zie figuur 1).

Figuur 1. Principetekening van de batchopstelling.

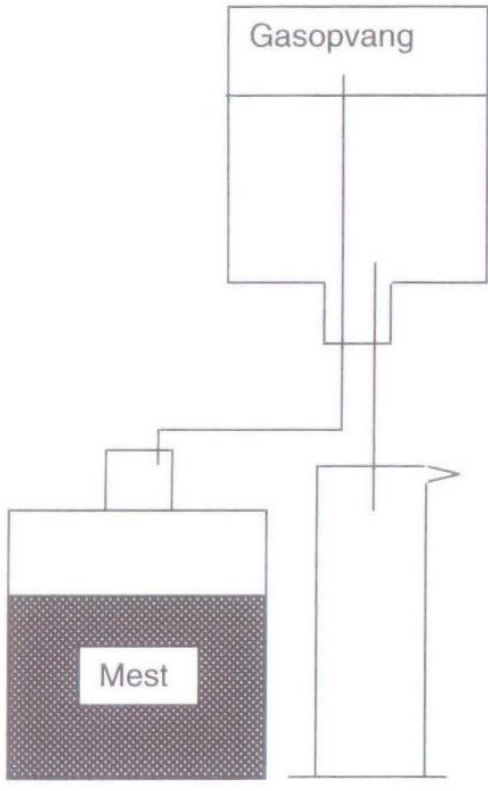

De vergelijking bestond uit de volgende series:

$$
\begin{array}{ll}
\text { - } & \text { drijfmest zonder Agrimest } \\
\text { drijfmest met Agrimest } \\
\text { - } & \text { drijfmest met Agrimest met micro-organismen. }
\end{array}
$$

Deze drie series in triplo uitgevoerd. 
In deze proef is gewerkt met zo vers mogelijke mest, afkomstig van PTC te Oenkerk. Deze mest bevatte een hoog droge stofgehalte en te weinig ureum ten opzichte van de gemiddelde literatuurwaarden voor drijfmest.

De verse mest is zodanig aangepast dat deze overeenkwam met het landelijke gemiddelde voor drijfmest voor wat betreft de verhouding $C, N, P$.

Alle batchopstellingen zijn gevuld met deze drijfmest. De opstellingen zijn in bedrijf gehouden onder mesofiele omstandigheden $\left(37^{\circ} \mathrm{C} \pm 2{ }^{\circ} \mathrm{C}\right)$.

De dosering van Agrimest en Agrimest met micro-organisme is volgens opgave van Rinagro toegediend in een verhouding van 1:36.000.

Per serie is, voordat deze in bedrijf genomen werd, een analyse gemaakt van de karakteristieken van de mest. Op dezelfde parameters zijn de series aan het eind van de test nogmaals geanalyseerd. In tabel 1 staan de parameters en de gebruikte analysemethoden.

Tabel 1. Parameters en de gebruikte analysemethoden.

\begin{tabular}{|l|l|}
\hline Parameters & Methode \\
\hline \hline Droge stof (ds) & NEN \\
\hline Organische stof (os) & NEN \\
\hline Chemisch Zuurstof Verbruik (CZV) & Dr. Lange \\
\hline Ammonium ( $\left.\mathrm{N}-\mathrm{NH}_{4}\right)$ & Stoomdestillatie \\
\hline Stikstof Totaal $(\mathrm{N}$-totaal) & Dr. Lange \\
\hline Gasvolume & Weging \\
\hline Zuurgraad $(\mathrm{pH})$ & $\mathrm{pH}$ meter \\
\hline
\end{tabular}

Het gasvolume is elke werkdag gemeten. 


\section{Resultaten}

De start van de vergisting was op 22 mei 2007. Einde van de experimenten was op 19 juli 2007.

De karakteristieken van de drijfmest bij aanvang van de vergisting, na de vergisting en de verschillen staan resp. weergegeven in de Tabellen 2, 3 en 4.

Tabel 2.
\begin{tabular}{|l||c||c||c|}
\hline Parameter & Mest & Mest met Agrimest & $\begin{array}{c}\text { Mest met Agrimest } \\
\text { en micro-organisme }\end{array}$ \\
\hline \hline droge stof & $3,0 \%$ & $3,2 \%$ & $3,6 \%$ \\
\hline $\mathrm{N}-\mathrm{NH} 4$ & $2133 \mathrm{mg} / \mathrm{l}$ & $2187 \mathrm{mg} / \mathrm{l}$ & $2036 \mathrm{mg} / 1$ \\
\hline $\mathrm{N}$-totaal & $4333 \mathrm{mg} / \mathrm{l}$ & $3977 \mathrm{mg} / \mathrm{l}$ & $3930 \mathrm{mg} / 1$ \\
\hline P-totaal & $299 \mathrm{mg} / \mathrm{l}$ & $282 \mathrm{mg} / 1$ & $277 \mathrm{mg} / 1$ \\
\hline $\mathrm{CZV}$ & $34,4 \mathrm{~g} / \mathrm{l}$ & $38,2 \mathrm{~g} / \mathrm{l}$ & $36,5 \mathrm{~g} / 1$ \\
\hline $\mathrm{pH}$ & 8,1 & 8,1 & 8,1 \\
\hline
\end{tabular}

Deze series werden in triplo ingezet. $\mathrm{Na}$ twee weken is de $\mathrm{pH}$ gecontroleerd van 1 van elke serie. $\mathrm{De} \mathrm{pH}$-waarde van alle drie series was $8,5 \pm 0,1$.

Tabel 3. Karakteristieken van de drijfmest per serie na vergisting.
\begin{tabular}{|l||c|c||c|c||c|c|}
\hline \multicolumn{1}{|c||}{ Parameter } & \multicolumn{2}{c||}{ Mest } & \multicolumn{2}{|c||}{ Mest met Agrimest } & \multicolumn{2}{|c|}{$\begin{array}{c}\text { Mest met Agrimest } \\
\text { en micro-organisme }\end{array}$} \\
\hline \hline droge stof (\%) & 2,5 & 2,4 & 2,7 & 2,5 & 2,5 & 2,7 \\
\hline N-NH4 (mg/l) & 2026 & 2176 & 2242 & 2236 & 2055 & 2013 \\
\hline N-totaal (mg/l) & 3860 & 3970 & 3680 & 3730 & 3740 & 3690 \\
\hline P-totaal (mg/l) & 282 & 283 & 266 & 301 & 256 & 253 \\
\hline $\mathrm{CZV}(\mathrm{g} / \mathrm{l})$ & 31,8 & 31,5 & 30,6 & 27,8 & 29,6 & 29,3 \\
\hline $\mathrm{pH}$ & 8,0 & 8,0 & 8,0 & 8,1 & 8,1 & 8,1 \\
\hline
\end{tabular}

\begin{tabular}{|c|c|c|c|c|c|c|}
\hline \multirow{2}{*}{$\frac{\text { Parameter }}{\text { droge stof }(\%)}$} & \multicolumn{2}{|c|}{ Mest } & \multicolumn{2}{|c|}{ Mest met Agrimest } & \multicolumn{2}{|c|}{$\begin{array}{l}\text { Mest met Agrimest } \\
\text { en micro-organisme }\end{array}$} \\
\hline & 17,67 & 18,7 & 17,19 & 23,1 & 29,44 & 26,1 \\
\hline $\mathrm{N}-\mathrm{NH} 4(\%)$ & 5,00 & $-2,0$ & $-2,53$ & $-2,3$ & $-0,91$ & 1,2 \\
\hline $\mathrm{N}$-totaal (\%) & 10,92 & 8,4 & 7,46 & 6,2 & 4,84 & 6,1 \\
\hline P-totaal $(\%)$ & 5,55 & 5,2 & 5,75 & $-6,6$ & 7,56 & 8,6 \\
\hline CZV $(\%)$ & 7,46 & 8,3 & 19,96 & 27,3 & 18,79 & 19,6 \\
\hline $\mathrm{pH}(\%)$ & 1,36 & 1,7 & 0,99 & 0,1 & 0,37 & 0,2 \\
\hline
\end{tabular}


Op elke werkdag is de geproduceerde hoeveelheid gas gemeten. Deze is uitgedrukt in $\mathrm{ml}$ per gram droge stof en uitgezet in grafiek 1 voor de eerste serie en in grafiek 2 voor de tweede serie.

\section{Grafiek 1. Eerste serie}

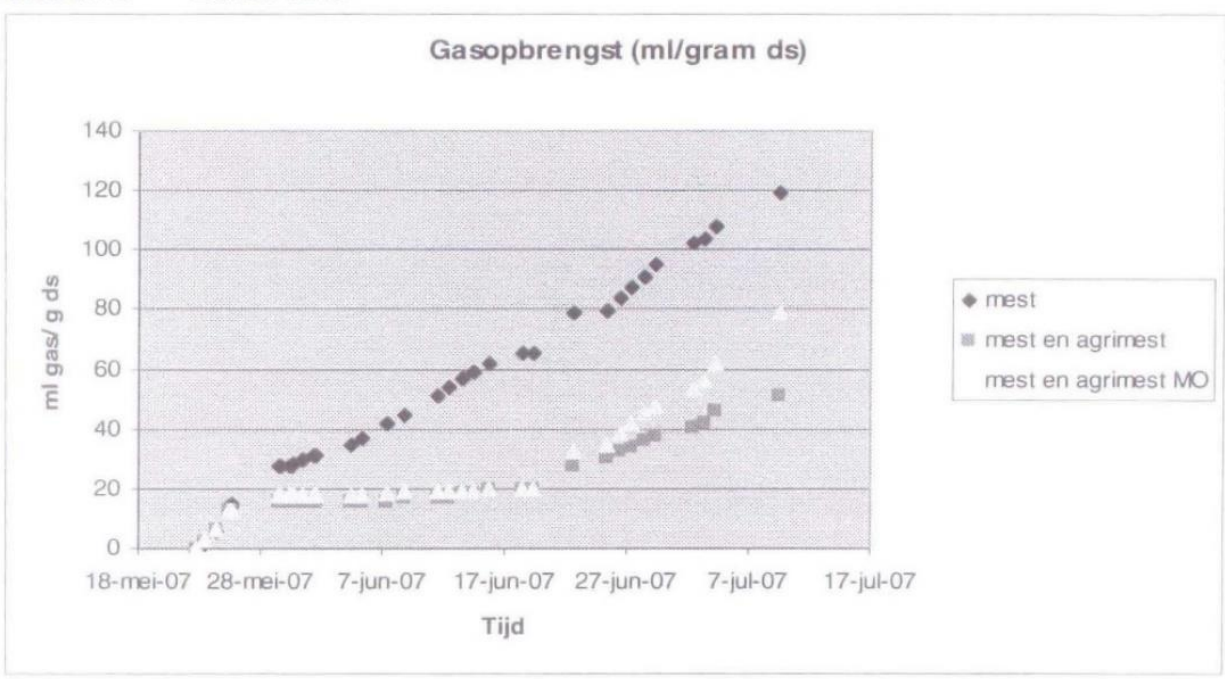

Grafiek 2. Tweede serie

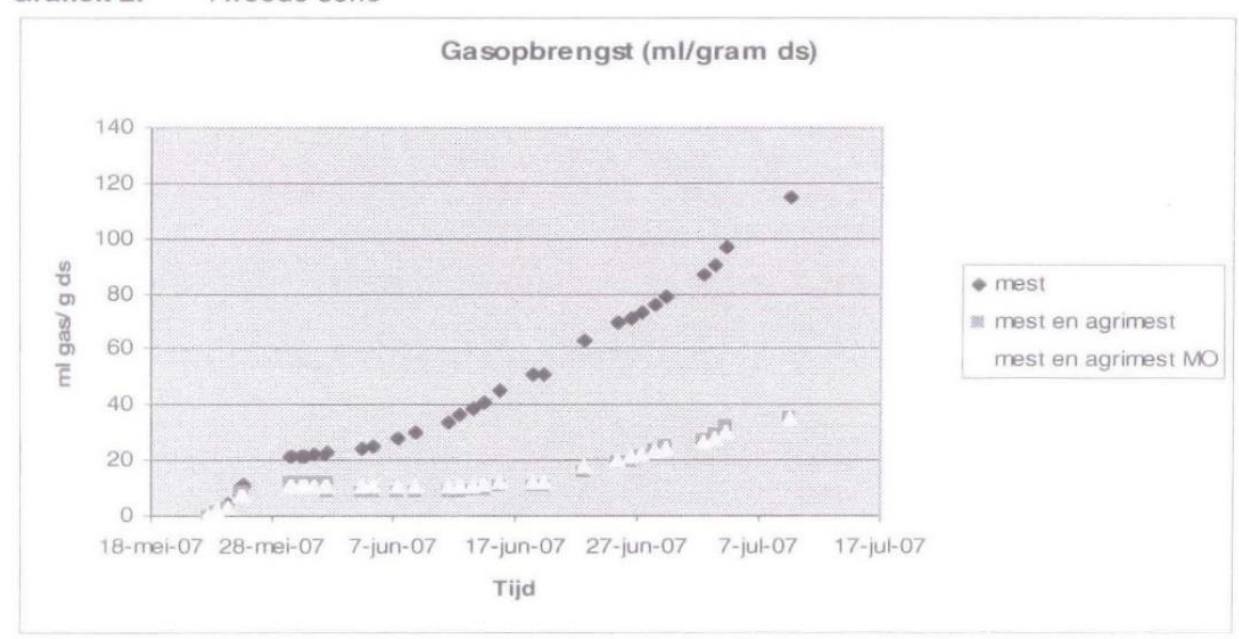




\section{Discussie}

De hoeveelheid gas die per gram droge stof wordt geproduceerd bij de vergisting van drijfmest met Agrimest en Agrimest met micro-organismen is beduidend minder dan bij mest zonder een van de producten.

In vergelijking met mest zonder toevoegingen blijkt dat de mest met toevoeging van Agrimest (al dan niet met micro-organismen) zelfs een remmende werking heeft op de gasproductie. De remming is zeer sterk in de eerste drie weken. Er is dan ook geen versnelde werking van de producten op de vergisting geconstateerd.

Uit de analyses blijkt echter wel dat de hydrolyserende fase, ondanks de geremde gasproductie, goed is. De droge stof afname is gelijk of zelfs hoger dan de vergistende mest zonder toevoegingen. Dit duidt op een remmende werking van de producten op uitsluitend de gasvormende (methanogene) fase van het vergistingsproces.

De remmende werking in alleen de methanogene fase biedt nieuwe perspectieven in de richting van andere toepassingen van de producten. 


\section{Conclusie}

- De producten Agrimest en Agrimest met micro-organismen geven, bij toepassing in drijfmest, geen verhoogde gasproductie ten opzichte van de controle.

- Agrimest en Agrimest met micro-organismen geeft een sterke remming van de methanogene fase (gasproductie) van de vergisting gedurende de eerste drie weken.

- De producten Agrimest en Agrimest met micro-organismen veroorzaken, bij toepassing in drijfmest, geen versnelling van het opstartproces van de vergisting.

\section{Aanbevelingen}

De remmende werking in de methanogene fase biedt nieuwe perspectieven in de richting van andere toepassingen van de producten.

Op welke wijze deze producten ingezet kunnen worden in nieuwe toepassingsgebieden zal nader onderzocht moeten worden. 


\section{Scientific Paper}

\section{Referentie:}

P.C.J. van Viiet, J. Bloem, R.G.M. de Goede, Microbial diversity, nitrogen loss and grass production after addition of Effective Micro-organisms $($ (EM) to slurry manure, Applied Soil Ecology, Volume 32, Issue 2, June 2006, Pages 188-198, ISSN 0929-1393, http://dx.doi.org/10.1016/j.apsoil.2005.07.001.

(http://www.sciencedirect.com/science/article/pii/S092913930500123X)

\section{Abstract:}

In this study, we used a DNA fingerprinting technique (PCR-DGGE) to investigate if bacteria present in an activated EM suspension (EM-A) were able to maintain or reach significant relative abundances after addition to slurry manure. We also investigated effects of the addition of EM-A to slurry manure on nitrogen losses from the manure and grass biomass production after application of the manure as

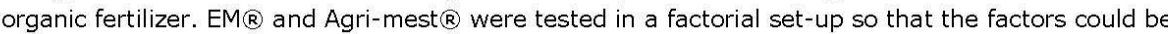
distinguished. Effective Organisms (EM) is a mixture of several effective, disease-depressing microorganisms. Agri-mest contains energized minerals, which will influence biochemical processes occurring in the manure.

Different EM-stocks, and EM-Active suspensions prepared by different users showed large variation in bacterial community structure and, thus, low reproducibility. Through the addition of Agri-mest to the slurry manure, loss of inorganic nitrogen from the slurry manure appeared to be reduced. Moreover, after application of such Agri-mest slurry as an organic fertilizer, nitrogen uptake by grass was reduced. Addition of EM-A had no measurable effects on the bacterial diversity and the chemical composition of the slurry manure. In a pot experiment, also no effects of EM on nitrogen uptake and grass biomass production were recorded.

Keywords: Bacterial diversity; Slurry manure; Manure quality; Effective Micro-organisms; DNA fingerprinting 
Effectieve Micro-organismen verhogen de kwaliteit van drijfmest waardoor minder stikstof verloren gaat, claimt de leverancier. De micro-organismen zouden de microbiële samenstelling van de mest veranderen en de emissie van ammoniak verminderen. De claims worden niet gestaafd door onderzoek van Wageningen Universiteit \& Researchcentrum.

\section{Effectieve Micro-organismen verbeteren kwaliteit runderdrijfmest niet}

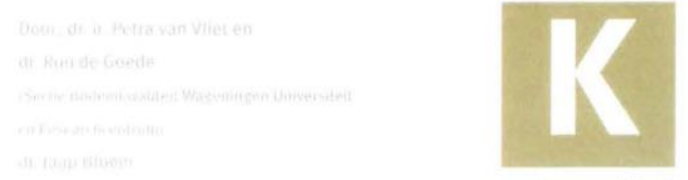
leven miliarden bacterien die wel in stat zijn de plantenvezels af te breken. De plantenresten die niet worden afgebroken, worden uitgescheiden in de mest. Er wordt in de mest nog een groot deel van de voedingsstoffen uit het gras terug. gevonden. Koeien benutten slechts 24 procent van de stikstof uit het gras en de overige 76 procent wordt uitgescheiden via mest en urine. Mest is aldus een rijke voedselbron voor planter Net als in de koe zijn het ook daar weer voora bacteriën die zorgen voor het vrijmaken van de resterende voedingsstoffen uit de mest.

Een groot deel van de urine- $\mathrm{N}$ wordt als ureum uitgescheiden; dit kan al op de stalvloer omgezet worden in ammoniak en kan dan direct vervluchtigen. Daarnaast worden in de mest aanwezige organische stikstofhoudende verbindingen door micro-organismen omgezet waarbi stikstof als ammonium kan vrijkomen. Gebeurt dit tijdens de opslag van de mest, dan kan de ammonium verloren gaan en vervluchtigen in de vorm van ammoniak; dat is ongewenst.

Sleutelen aan de bacteriegemeenschap Bacteriën spelen bij dit alles dus een cruciale rol. Daarom lijkt het aanpassen van de samenstel. ling van de bacteriegemeenschap in de mest een interessante optie om het aanbod van opneem. bare stikstofverbindingen voor planten te optima liseren. Ook kan zo de emissie van ammoniak uit de mestopslag worden beperkt. Volgens de leverancier kunnen Effectieve Micro-organismen (EM) hierbij helpen. Dit product betreft een mengsel van diverse soorten microscopische organismen (zie kader), voornamelijk bacterièn. die na toevoeging aan de mest een belangriike rol spelen in onder meer het vrijmaken en vastleggen van stikstof.

\section{Onderzoek}

In ons onderzoek zijn we uitgegaan van het in de handel verkrijgbare product 'Effectieve Micro organismen-EM: Met DNA-onderzoek is een schatting gemaakt van het aantal aanwezige bacteriesoorten. Bij bacterièn is het onderscheid tussen soorten een lastig begrip. Daarom wordt hier met 'soort' in feite genotype bedoeld. Een type met een bepaalde genetische samenstelling die kan worden onderscheiden van andere typen.

EM kan niet direct aan de mest worden toege. voegd. Door er water en melasse aan toe te voe gen gaan de micro-organismen zich vermeerderen en ontstaat na zeven dagen het zogeheten EM-Actief. Vervolgens werd de EM-Actief toegevoegd aan drijfmest: $2 \mathrm{ml}$ EM-Actief bij to liter drijfmest. Omdat de producent adviseert om naast EM-Actief ook Agri-Mest toe te voegen hebben we in het onderzoek EM-Actief zowel met als zonder Agri-Mest gebruikt.

Volgens leverancier Agriton (Noordwolde) bestaat Agri-Mest uit 'geënergetiseerde minera. len die een belangrijke rol spelen bij enkele gecompliceerde biochemische processen'. AgriMest kan de omstandigheden in de drijfmest zodanig beïnvloeden dat onder andere meer energie beschikbaar komt en micro-organismen een anaërobe fermentatie kunnen uitvoeren. Per behandeling waren er vier emmers met mest, die gedurende zes weken afgesloten werden bewaard (met luchtgaten in de deksel) bij $20{ }^{\circ} \mathrm{C}$. Twee keer per week werden de emmers geroerd om korstvorming te voorkomen. Na zes weken zijn er bacterie- en chemische bepalingen uitgevoerd en ten slotte is in een potproef onderzocht of EM-drijfmest effect heeft op de groei en stikstofopname van gras. 


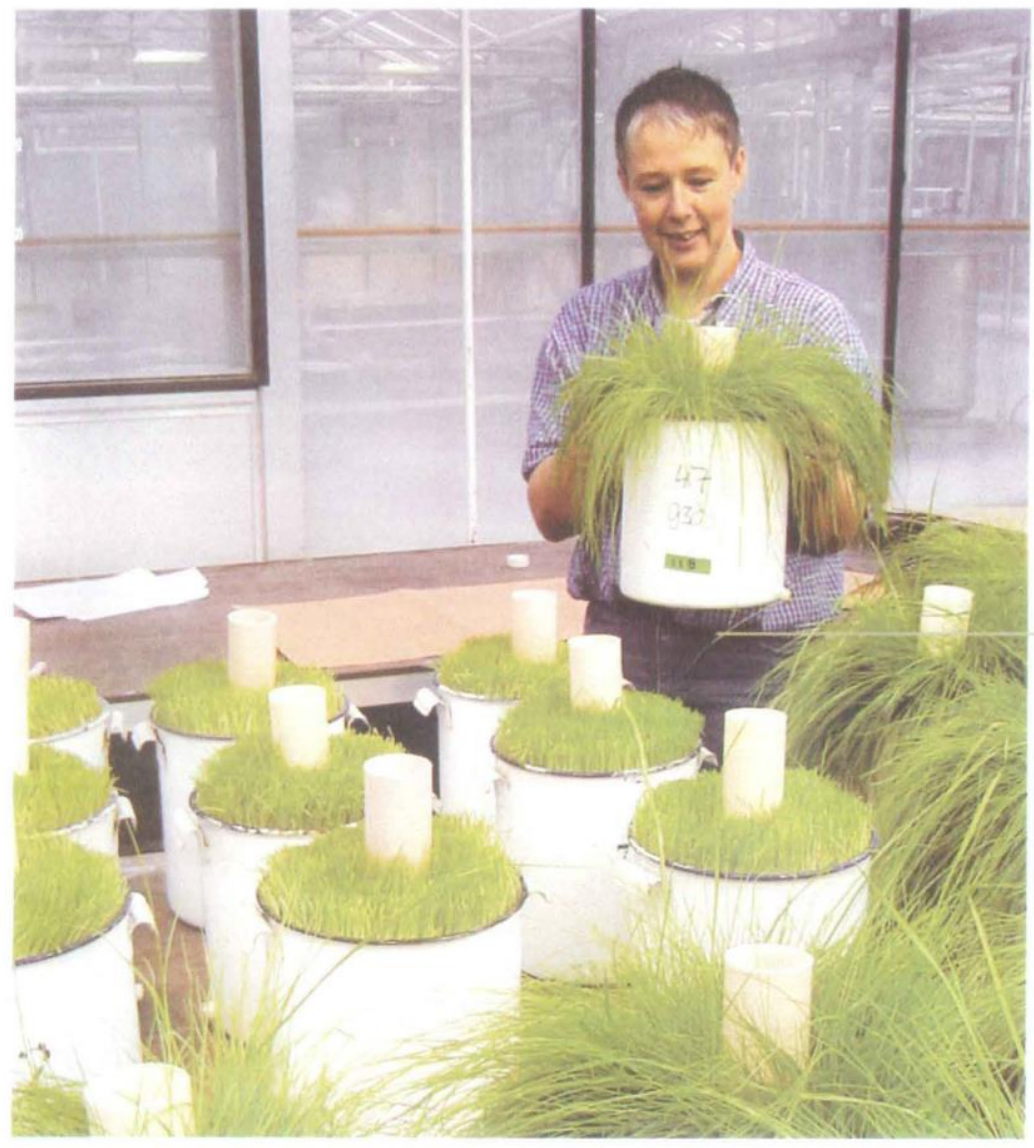

\section{POTPROEF}

De eerste snede gras wordt geoogst. In de potproef is de grasopbrengst vergeleken bij gebruik van verschillende mestcombinaties (met en zonder EM-Actief en met en zonder Agri-Mest). De grasopbrengsten bij de verschillende soorten mest verschilden niet van elkaar.

Foto: Wageningen Universitetit 8 Researchcentrum

\section{Agri-Mest versus Efectieve Micro-organismen}

Chemische gegevens van de verschillende mesten op dag o en na 56 dagen (bij $20^{\circ} \mathrm{C}$ ). A=Agri-Mest en EM=Effectieve Micro-organismen.

\begin{tabular}{|c|c|c|c|c|c|c|c|c|c|c|}
\hline Mest & Dag & $\begin{array}{l}\text { Drogestof } \\
90\end{array}$ & $\begin{array}{l}\mathrm{pH} \\
\%\end{array}$ & $\begin{array}{l}\text { Koolstof } \\
\% \text { DM }\end{array}$ & $\begin{array}{l}\text { Stikstof } \\
\text { hy proton }\end{array}$ & $\begin{array}{l}\mathrm{N}_{\text {organisch }} \\
\text { g Plyy DS }\end{array}$ & $\begin{array}{l}N_{\text {mineraal }} \\
(\mathrm{g} / \mathrm{kg} \text { ds })\end{array}$ & $\begin{array}{l}\text { Statistisch } \\
\text { verschil }\end{array}$ & $\begin{array}{c}\mathrm{N}_{\min } / \mathrm{N}_{\mathrm{org}} \\
(\mathrm{g} / \mathrm{kg} \mathrm{ds})\end{array}$ & $\begin{array}{l}\text { Statistisch } \\
\text { verschil }\end{array}$ \\
\hline$-A-E M$ & dag o & 6,24 & 7,04 & 35,45 & 4.06 & 22,61 & 17.95 & a & 0,80 & a \\
\hline$-A+E M$ & & 6,41 & 7,02 & 35,22 & 3.98 & 21,51 & 18,28 & a & 0,85 & a \\
\hline$+A-E M$ & & 6,38 & 6,99 & 35,29 & 4,05 & 22,27 & 18,25 & a & 0,83 & a \\
\hline$+A+E M$ & & 6,30 & 6,97 & 35,49 & 4,04 & 22,11 & 18,26 & a & 0,83 & a \\
\hline$-A-E M$ & dag 56 & 5,62 & 7.53 & 38,16 & 3.31 & 22,94 & 10,14 & B & 0,44 & B \\
\hline$-A+E M$ & & 5,66 & 7.51 & 36,56 & 3.77 & 23.73 & 13.97 & $A B$ & 0,60 & $A B$ \\
\hline$+A-E M$ & & 5,80 & 7.53 & 35,10 & 3.95 & 21,57 & 17,93 & A & $0,83^{\ell}$ & A \\
\hline$+A+E M$ & & 5,70 & 7.52 & 37,03 & 3.75 & 23,52 & 13,96 & $A B$ & 0,59 & $A B$ \\
\hline
\end{tabular}

Verklaringen

$-=$ zonder toevoeging mestsoort; $+=$ met toevoeging mestsoort

Het percentage drogestof, de $\mathrm{pH}$, het percentage stikstof en koolstof in de verschillende mesten verschillen niet als per datum wordt vergeleken. De hoeveelheid minerale stikstof is na zes weken het hoogst in de behandeling: +Agri-Mest -EM. Dit heeft tot gevolg dat de verhouding $\mathrm{N}_{\mathrm{mine}}$

$N_{\text {organisch }}\left(\mathrm{N}_{\mathrm{min}} / \mathrm{N}_{\text {org }}\right)$ het hoogste is in deze behandeling. De letters geven statistisch significante verschillen aan. Als er geen letters staan. waren de behandelingen statistisch gezien niet verschillend van elkaar. 


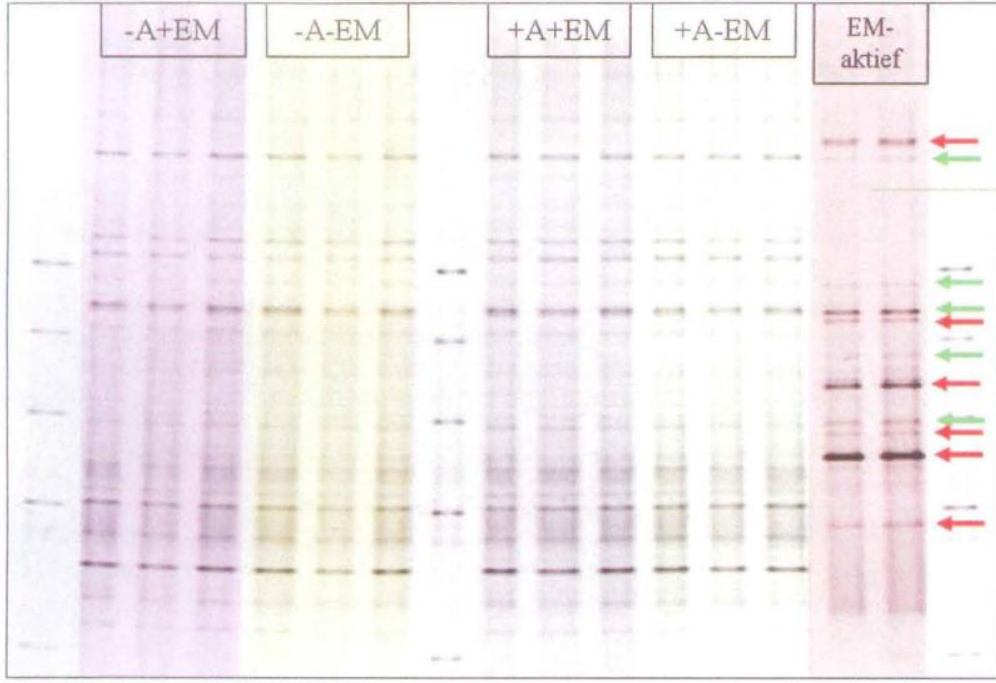

\section{Grote verschillen}

In het onderzoek werd tweemaal een EM-startoplossing verkregen van de leverancier. In de ene EM-oplossing vonden we twaalf bacteriesoorten en in de andere vijftien. De soortensamenstelling van beide oplossingen was erg verschillend. De overeenkomst was slechts 50 procent. De EM-oplossingen werden gebruikt voor het maken van EM-Actief. In één van de EM-Actief oplossingen vonden we geen bacteriesoorten terug, wat mogelijk kwam door een lage. re incubatietemperatuur $\left(12^{\circ} \mathrm{C}\right)$ dan wenselijk is $\left(23^{\circ} \mathrm{C}\right)$. In twee EM-Actief oplossingen die wel bij $23^{\circ} \mathrm{C}$ waren gemaakt, werden respectieveliik gemiddeld 17 en 26 bacteriesoorten aangetroffen. De overeenkomst in soortensamenstelling tussen de beide EM-Actief oplossingen was laag (6o procent).

Uit het onderzoek blijkt dus dat er diverse soorten bacteriën in het uitgangsproduct EM aanwezig zijn, maar dat de samenstelling van het product variabel is. Activering van EM tot EM-Actief leidt tot een toename van het aantal aantoonbare soorten, mar het resultaat is erg wisselend.

\section{Gevecht om een plek}

In de drijfmest zaten van nature gemiddeld 36 soorten bacteriën. De met EM-Actief toegevoeg. de bacterièn moeten met de natuurlijke soorten concurreren om de nutriènten. We vonden echter geen enkel verschil in de soortensamenstellingen in mest, waaraan wel of juist geen Effectieve Micro-organismen waren toegevoegd. Beide mestproducten leken sterk op elkaar ( 88 procent overeenkomst). Sommige soorten bacterièn in de EM-Actief zaten van nature al in de drijfmest. Andere soorten die uniek waren voor de EM-Actief, konden na toevoeging aan de drijfmest niet meer worden teruggevonden. We vonden aldus geen aanwijzingen dat de bacterie. soorten van het Effectieve Micro-organismen mengsel zich vermenigvuldigen en handhaven in de drijfmest.

\section{Geen plek... geen effect}

Aangezien geen van de bacteriesoorten uit EMActief overduidelijk aanwezig is in de mest, lijken effecten van EM op het vastleggen van stikstof in organische vorm niet waarschijnlijk. De chemische analyses bevestigden de resultaten: er waren geen verschillen in zuurgraad $(\mathrm{pH})$, drogestofgehalte, totaal gehalte aan stikstof en koolstof, en concentraties plantopneembare stikstof (zie tabel. pagina 19).

Wel werden veranderingen aangetoond als AgriMest werd toegevoegd. Bij gebruik van AgriMest bleef het minerale stikstofgehalte in de drijfmest hoger dan in onbehandelde mest. Misschien dat de ammoniakvervluchtiging in deze mest lager was.

In een potproef werd vervolgens onderzocht of de verschillende drijfmesten effect hadden op de groei van Engels raaigras. Door de bovengrond in de pot werd het equivalent van 20 ton per ha EM-Actief op de grasgroei en de stikstofopname. Wel leidde het gebruik van Agri-Mest tot een iets lagere stikstofopname door het gras. Dit is opmerkelijk omdat bij het relatief hoge gehalte van minerale stikstof, het tegenovergestelde werd verwacht. Mogelijk wordt de minerale stikstof sterker geadsorbeerd bij gebruik van AgriMest. Daarnaast is het mogelijk dat de minerale stikstof in de grond alsnog verloren is gegaan. drijfmest gemengd. Er was geen enkel effect van

\section{N A - PROFIELEN}

DNA-profielen van mest met (+) en zonder (-) Effectieve Micro-organismen (EM) en Agri-Mest (A). Elke band is een bacteriesoort. Met de gekleurde pijlen is aangegeven of de bacteriesoorten aanwezig in de EM-actief ook in de mesten aanwezig zijn. Groene pij: de bacteriesoort is aanwezig in de EM-actief maar ook in alle mestbehandelingen. Rode pijl: de bacteriesoort is aanwezig in de EM-actief, maar niet in de mestbehandelingen waaraan de EM-actief is toegevoegd. Foto: Wageningen Universiteit \& Researchcentrum

\section{Conclusie}

Ons onderzoek vindt geen positieve effecten van het toevoegen van Effectieve Microorganismen (EM) aan mest, ook niet in combinatie met het handelsproduct Agri-Mest. Allereerst bleek de samenstelling van het uitgangsproduct (EM) zeer wisselend. Daarnaast werden de bacteriën van het EM-preparaat niet teruggevonden in de mest en hadden ze ook geen effect op de chemische samenstelling en de werking van de mest. Deze resultaten zijn niet verrassend als we de verhoudingen bekijken. Het blijkt onmogelijk om met toevoeging van slechts tweeduizendste liter van een 'uitgebalanceerd' microorganismenmengsel aan 10 liter drijfmest (verdunning 1:5.000) in zes weken tijd de samenstelling van de natuurlijke microbiële gemeenschap in driffmest te veranderen.

Dit ondarzoek werd gefinancieerd door Stichting Kemis. ontwikkeling \& Kennisoverdracht Bodem en Wageningen Universiteit \& Researchcentrum 


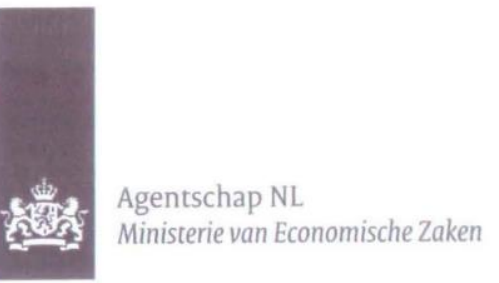

OCTROOINUMMER 2009019

NL Octrooicentrum verklaart dat op grond van octrooiaanvrage 2009019, ingediend op 15 juni 2012, octrooi is verleend aan:

Rinagro B.V. te Piaam

Uitvinder(s): Rinze Joustra te Piaam

voor:

Inrichting, gebruik van een dergelijke inrichting, en werkwijze voor het aanbrengen van een bepaalde hoeveelheid van een mestbewerking-substantie op mest, alsmede mest waarop een bepaalde hoeveelheid van een mestbewerking-substantie op aangebracht is.

Aan dit bewijs is een exemplaar van het octrooischrift gehecht met nummer 2009019 en dagtekening 3 juli 2013.

De maximale beschermingsduur van dit octrooi loopt tot en met 14 juni 2032

Uitgereikt te Den Haag, 10 juli 2013.

NL Octrooicentrum

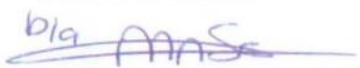

mw. C.M.A. Streng 


\subsection{Analyseresultaten bij Agri-Mest gebruik}

Vers gas Onderzueh

Tabel 13: Gemiddeide waarden opgedeeld in Agri-Mest gebruikers en niet gebruikers.

\begin{tabular}{|c|c|c|c|c|c|c|}
\hline & & RE & suiker & $\mathrm{NO}_{3}$ & DVE & OEB \\
\hline & \multirow{3}{*}{$\begin{array}{l}\text { Zand wel, proefveld A } \\
\text { Veen wel, proefveid A } \\
\text { Klei wel, proefveid A }\end{array}$} & 163 & 152 & 1.5 & 96 & 0 \\
\hline & & 168 & 144 & 0,8 & 95 & 6 \\
\hline & & 173 & 146 & 1,2 & 96 & 10 \\
\hline \multirow[t]{4}{*}{1.} & Gem. Proefveld A, AgriMlest gebrulkers & 168 & 147 & 1,17 & 96 & 5 \\
\hline & Zand niet, proefveid A & 94 & 299 & 0 & 86 & -61 \\
\hline & Veen niet, proefveid A & 141 & 179 & 0.5 & 91 & -17 \\
\hline & Kieı niet, proefveid A & 146 & 169 & 0,6 & 93 & -14 \\
\hline 2 & Gem. Proefveid A, niet Agri-Mest gebruikers & 127 & 216 & 0,37 & 90 & -31 \\
\hline
\end{tabular}

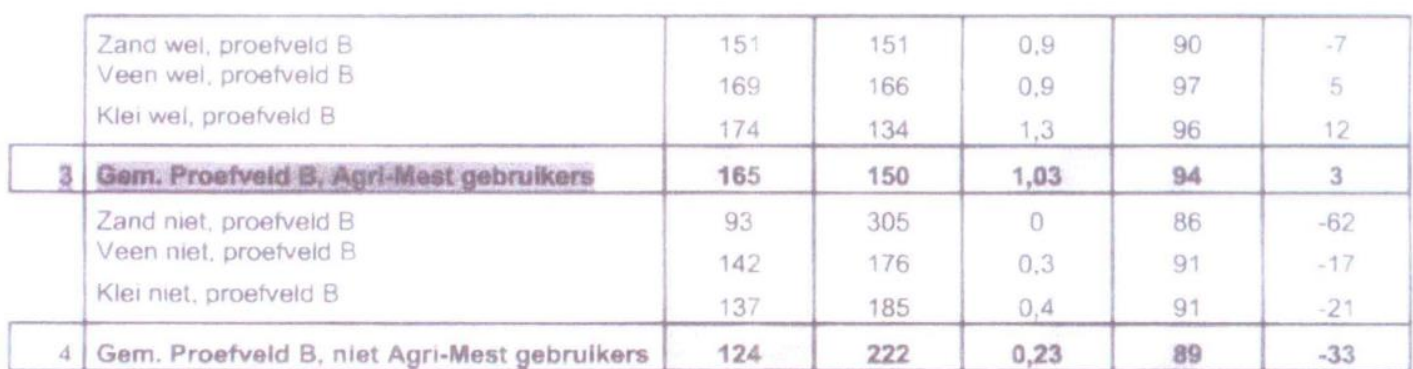

\begin{tabular}{|c|c|c|c|c|c|c|}
\hline & Zanc wei, perceel & 179 & 153 & 1.4 & 100 & 12 \\
\hline & Veen wel, perceel & 198 & 169 & 1.3 & 104 & 28 \\
\hline & Klei wel, perceel & 172 & 129 & 1,3 & 95 & 10 \\
\hline \multirow[t]{4}{*}{5} & Gem. perceel, Agri-Nest gebrulkers & 183 & 150 & 1,33 & 100 & 17 \\
\hline & Zand niet & 87 & 311 & 0 & 84 & -66 \\
\hline & Veen niet & 121 & 231 & 0 & 92 & -38 \\
\hline & Klei niet & 158 & 133 & 0,9 & 91 & 0 \\
\hline 6 & Gem. perceel, niet Agri-Mest gebrulkers & 122 & 225 & 0,3 & 89 & -35 \\
\hline
\end{tabular}

In tabel 13, welke grafisch is uitgebeeld in figuur 10 , is duidelijk verschil waarneembaar bij enkeie kenmerken. Zo is het ruw eiwit $\pm 40 \mathrm{gr} / \mathrm{kg}$ hoger bij de Agri-Mest gebruikers dan bij de niet gebruikers. Als het ruw eiwit omhoog gaat, gaat het suiker omlaag. Ook het darm verteerbaar eiwit (DVE) en de onbestendig eiwit balans (OEB) is bij de AgriMest gebruikers hoger dan bij de niet-gebruikers.

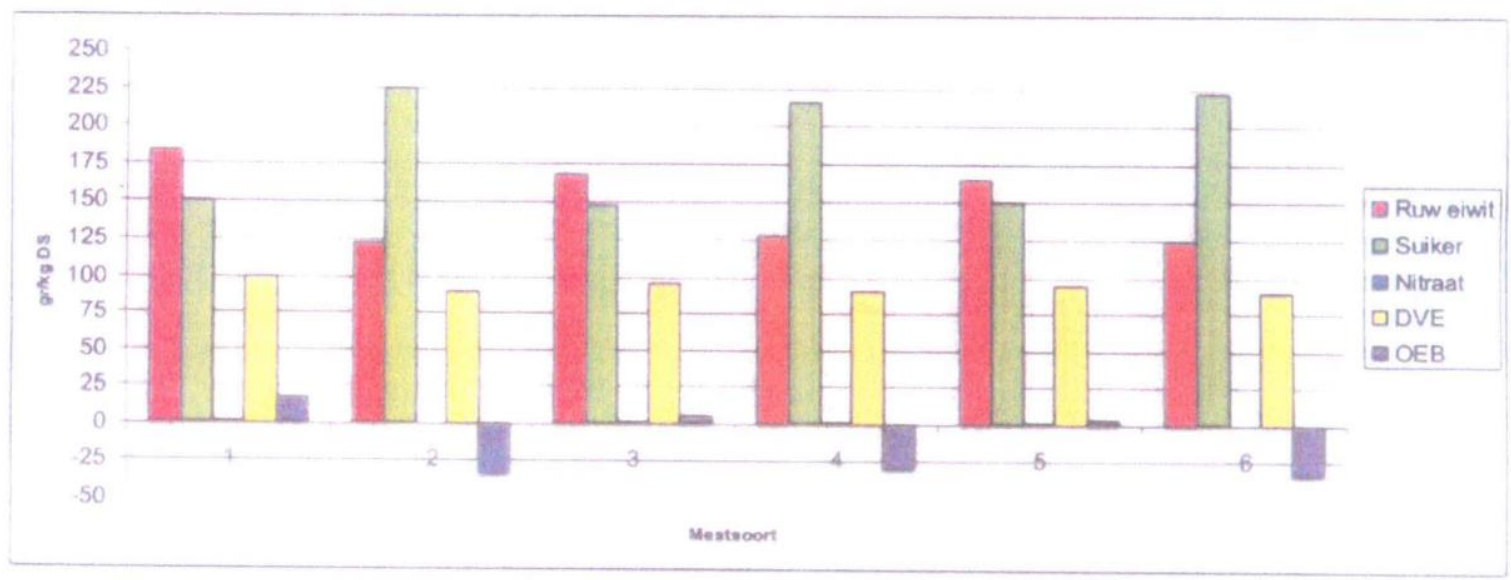


Verkenning vermindering uitstoot broeikasgassen uit opslag vaste mest

Derk van Balen

Uitgangspunten

- Vaste rundveepotstalmest

- Tijdelijke opslag op veld

- Toediening vlak voor zaai snijmais

Opzet

- Mesthoop standaard

- Mesthoop met toevoeging

- Mesthoop met $20 \mathrm{~cm}$ compost afgedekt

- Composthoop

3 meetpunten (containers) per object

6 tijdstippen gemeten (tussen 23 februari en 25 mei)

Géén herhalingen, slechts verkenning!
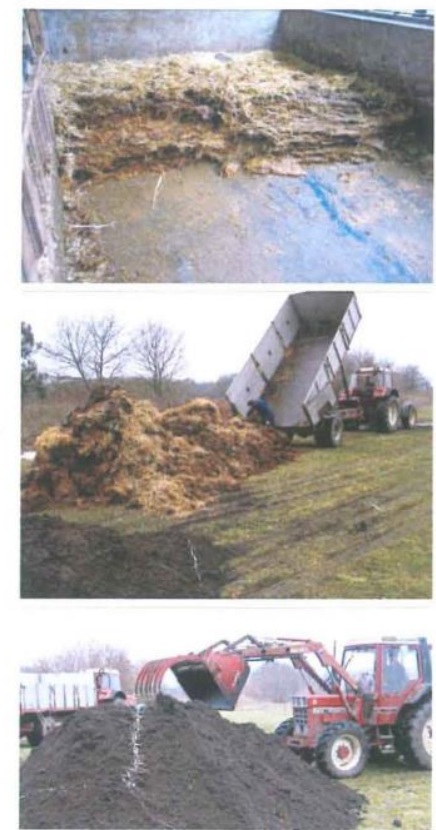

Uitstoot van broeikasgassen uitgedrukt in $\mathrm{CO} 2$ equivalenten

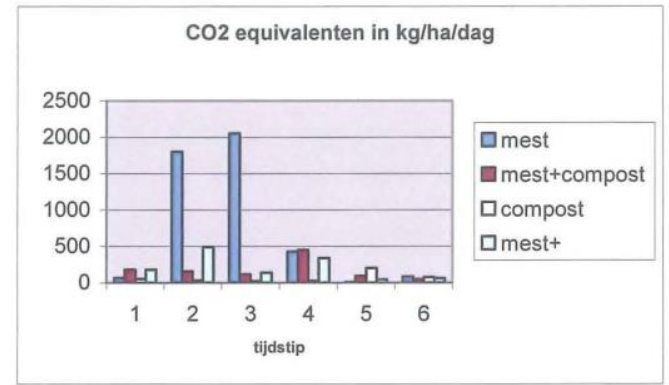

\begin{tabular}{|l|r|r|r|r|r|r|}
\hline tijdstip & 1 & 2 & 3 & 4 & 5 & 6 \\
\hline datum & 23 februari 2010 & 3 maart 2010 & 11 maart 2010 & 17 maart 2010 & 25 mei 2010 & 26 mei 2010 \\
\hline
\end{tabular}

Temperatuur gemeten in de mest/composthoop

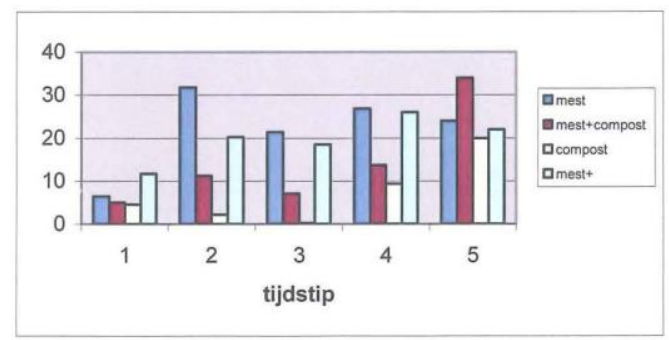

Ervaringen

- Verkenning geeft aanknopingspunten voor verder onderzoek

- Grote variatie van metingen binnen de mesthoop

- Permanente opstelling metingen wenselijk

- Compostkwaliteit sterk bepalend voor beluchting van de mesthoop

- Geen harde conclusies te trekken, verder onderzoek noodzakelijk

Deze verkenning is uitgevoerd in opdracht van de Innovatiegroep Energie en Broeikasgassen van Bioconnect 


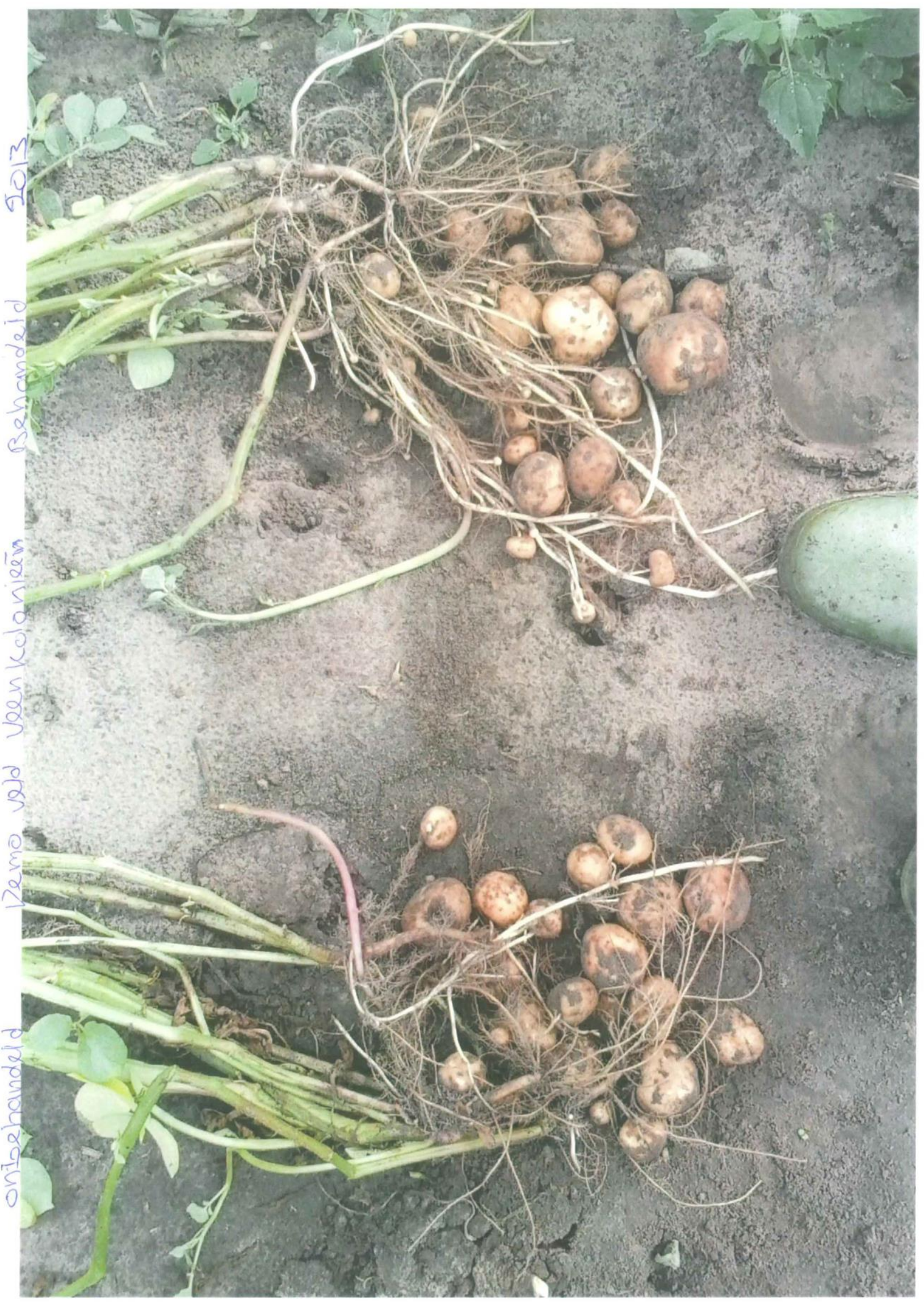




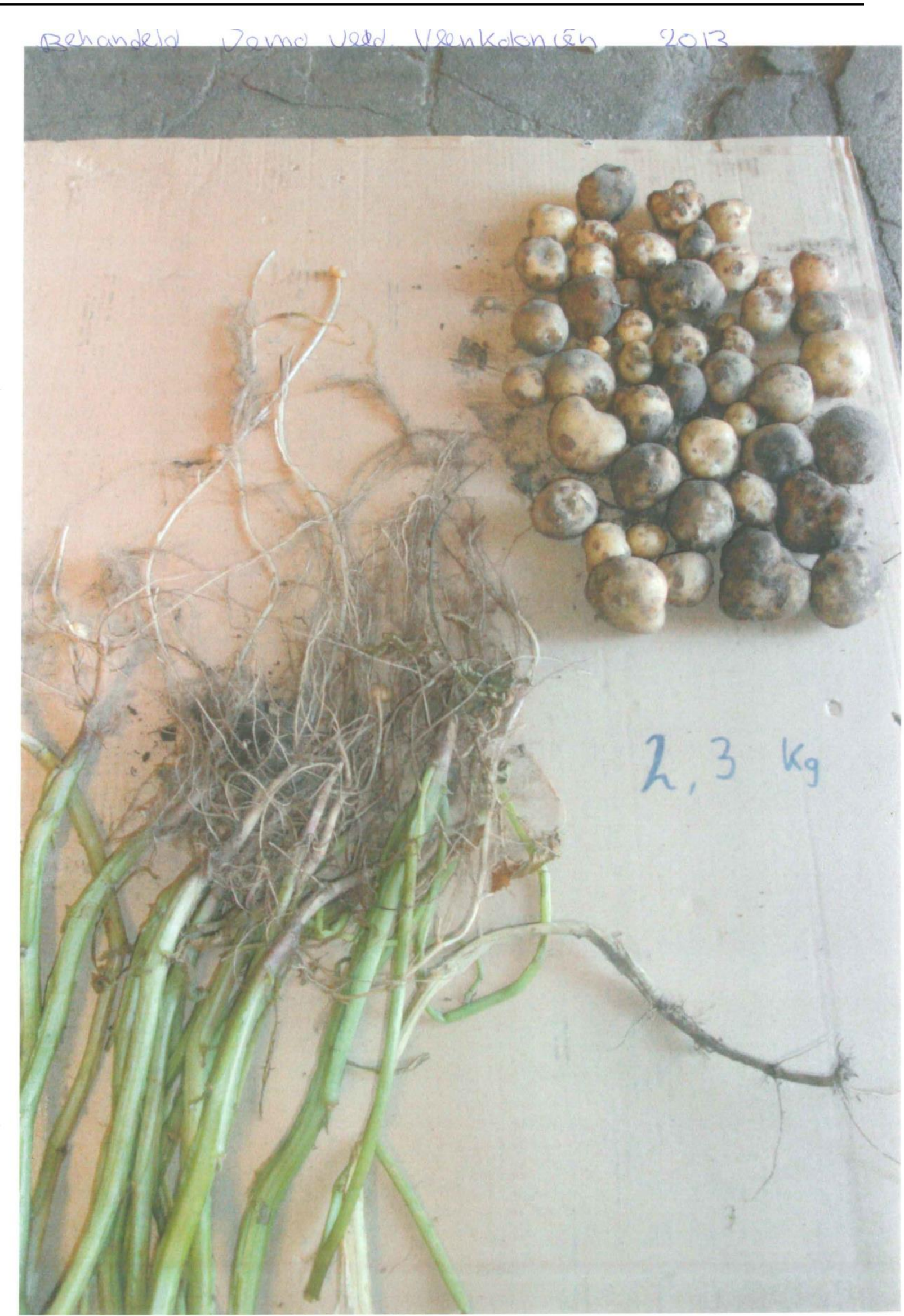




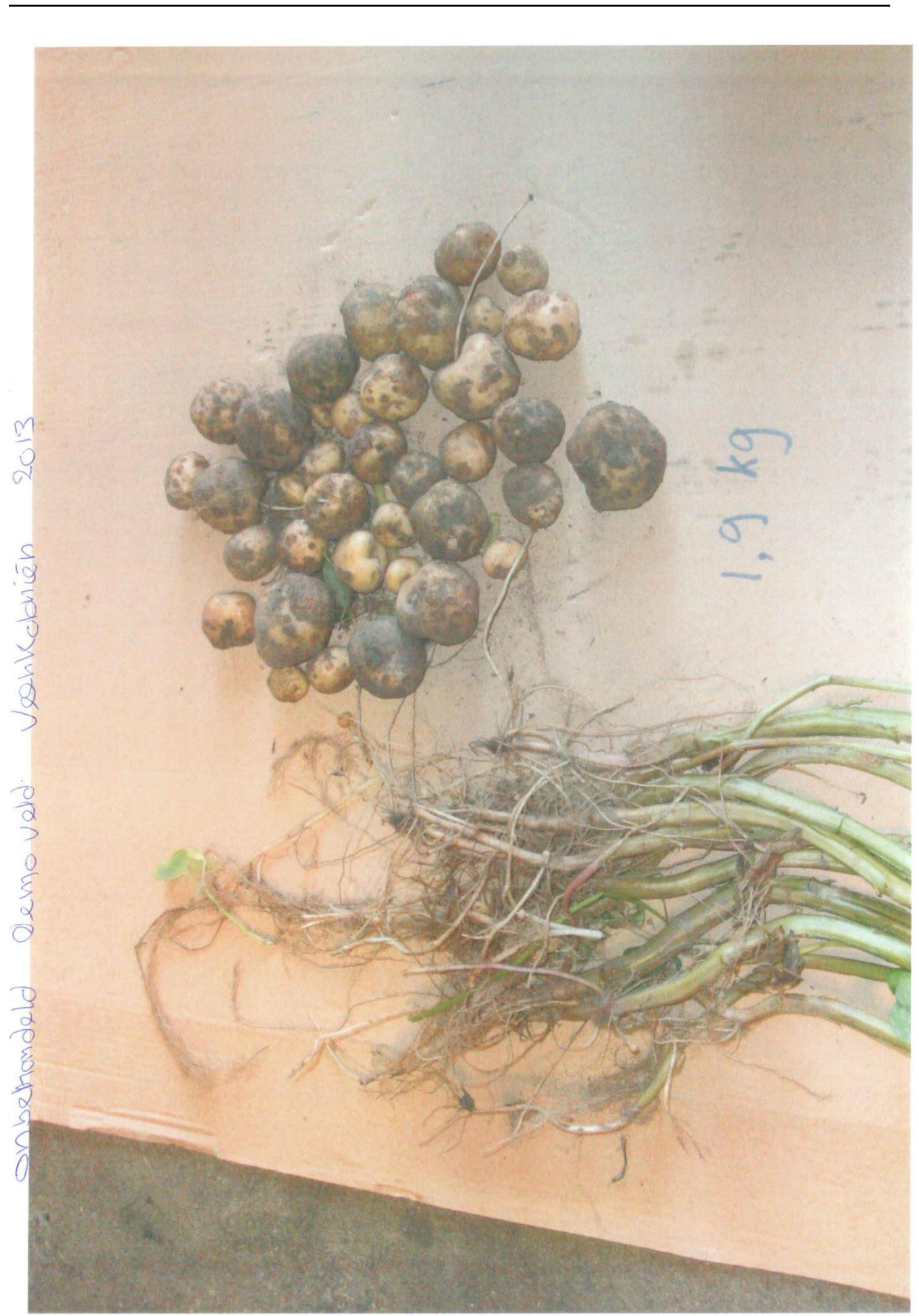




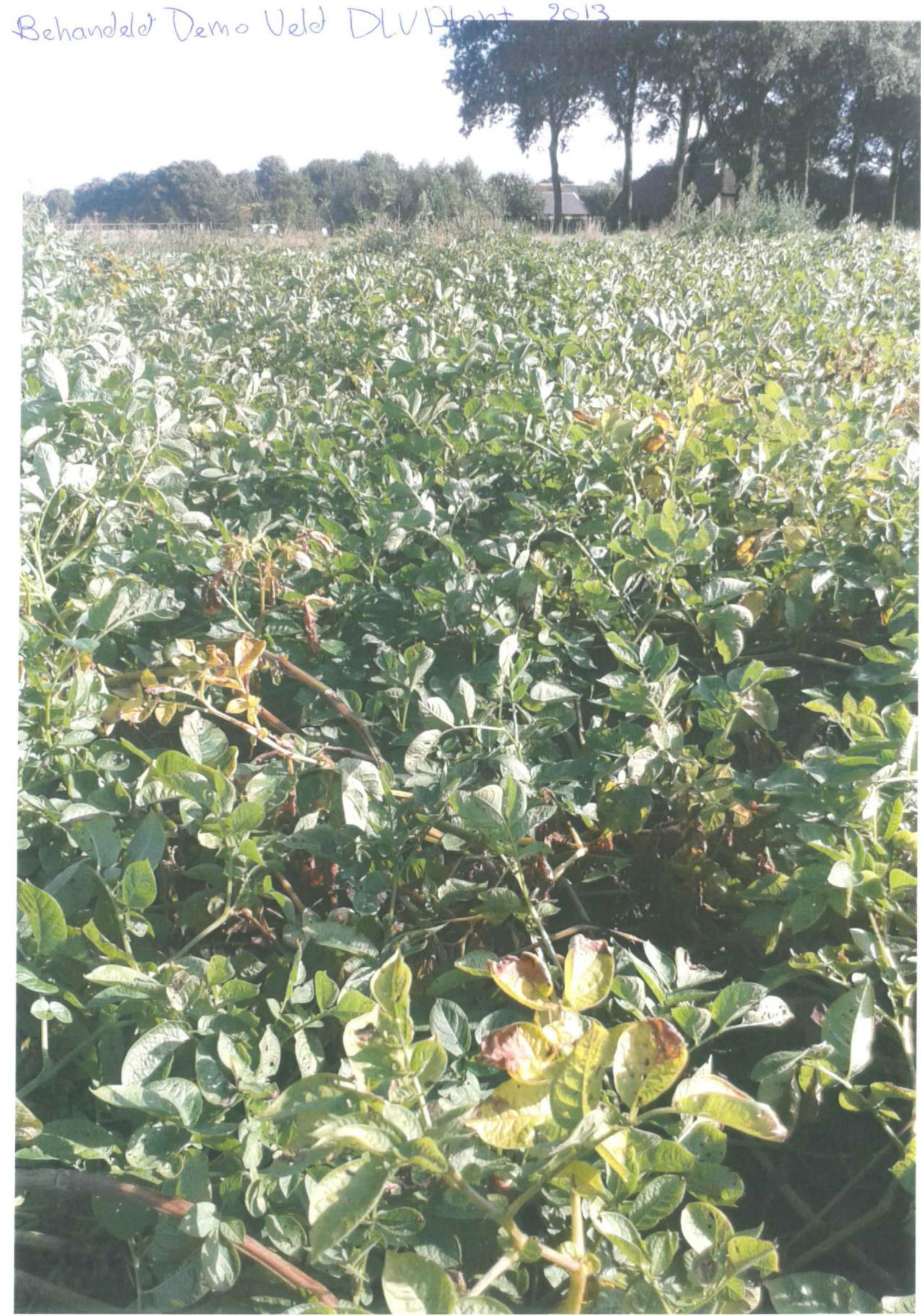


Onbehandeld Oemoveld OLV Plant 2013

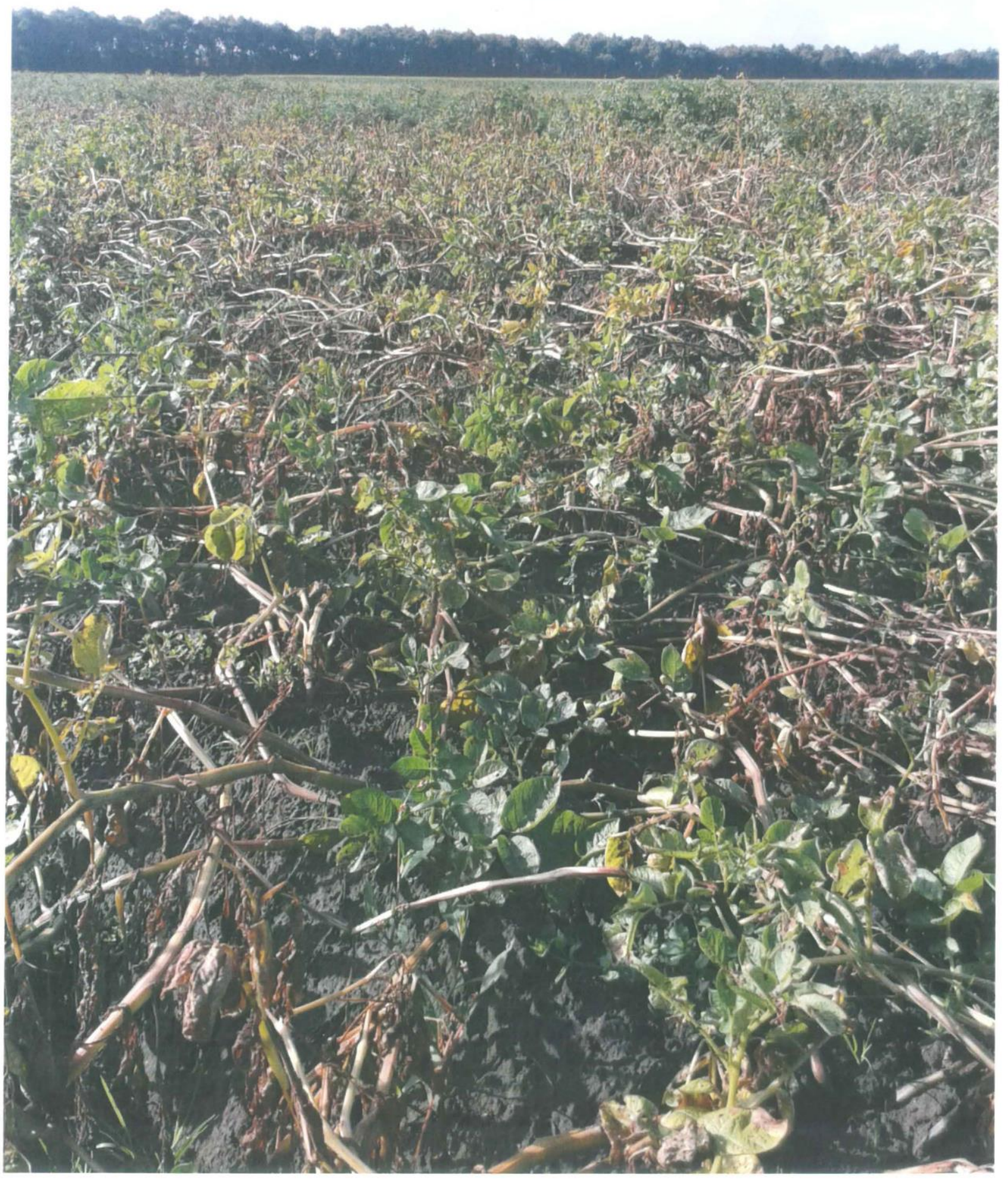


4.2 Samenvatting rapport Blauw (BL2012.5216.02-V04, maart 2013) 


\section{SAMENVATTING}

Buro Blauw heeft in opdracht van Rinagro uit Piaam een meetprogramma uitgevoerd voor het vaststellen van de ammoniakemissiereductie voor stalsystemen voor vleesvarkens met een installatie voor mestbewerking.

De doelstelling van de metingen is de ammoniakemissie van deze installatie vast te stellen die opgenomen kan worden in de Regeling Ammoniak Veehouderij (RAV). Hiertoe is door Buro Blauw een meetplan opgesteld, welke positief geadviseerd is door de Technische Advies Commissie RAV. Het meetplan bestond uit het uitvoeren van ammoniakemissiemetingen gedurende $6 * 24$ uur bij 2 stallen met 2 identieke lokalen. Dit is de zogenaamde case - control methode. De metingen zijn uitgevoerd bij de volgende veehouderij bedrijven:

1. Van de Beek - Putten

2. Van de Brandhof - Ede -

De diercategorie in de lokalen waar de metingen zijn uitgevoerd bij Van de Beek in Putten valt onder Rav code D.3.2.1.2. De door Buro Blauw gemeten emissiefactor van de referentieafdeling van Van de Beek in Putten bedraagt 6,3. $\mathrm{Kg} \mathrm{NH}_{3}$ per dier per jaar (incl. $10 \%$ leegstand). Dit is hoger dan de emissiefactor die is opgenomen in bijlage 1 van de Rav (4,0 Kg NH 3 per dier per jaar). Dit kan verklaard worden door het feit dat de varkens al zwaarder zijn als ze het lokaal in komen.

De diercategorie in de lokalen waar de metingen zijn uitgevoerd bij Van de Brandhof in Ede valt onder Rav code D.3.2.1.1. De door Buro Blauw gemeten emissiefactor van de referentieafdeling van Van de Brandhof in Ede bedraagt 1,8. $\mathrm{Kg} \mathrm{NH}$ per dier per jaar (incl. $10 \%$ leegstand). Dit is lager dan de emissiefactor die is opgenomen in bijlage 1 van de $\mathrm{Rav}(3,0 \mathrm{Kg} \mathrm{NH}$ per dier per jaar). Dit verschil wordt verklaard door de nieuwheid van de stal.

Het meetprogramma is conform het meetplan uitgevoerd in de periode juli $2011 \mathrm{t} / \mathrm{m}$ maart 2012. De metingen zijn storingsvrij verlopen. Bij de 2 bedrijven zijn metingen uitgevoerd in de zes delen van de groeicyclus van vleesvarkens. Er zijn in totaal 4 metingen in de winter, 4 metingen in de zomer en 4 metingen in het voor- of najaar uitgevoerd. De metingen op de twee locaties zijn voor wat betreft de groeifase redelijk verdeeld over de seizoenen uitgevoerd. Hiermee is voldaan aan de organisatorische vereisten voor de uitvoering van het onderzoek.

Bij beide bedrijven is sprake van een gelijk aantal dieren in de case- en controlafdeling. Ook is sprake van een klein acceptabel verschil in gewicht van de dieren in beide afdelingen. Hierbij is sprake van een geslaagde meetopzet voor de case - control methode.

Uit de metingen is een duidelijk verschil naar voren gekomen in de ammoniakemissiereductie bij de beide bedrijven. Bij Van de Beek in Putten is een gemiddelde reductie gemeten van $35 \%$ en bij Van de Brandhof in Ede van $17 \%$. Hiermee is een gemiddelde ammoniakemissiereductie van $26 \%$ aangetoond. 
Het verschil in de gemeten ammoniakemissiereductie bij van de Beek en van de Brandhof kan worden toegeschreven aan de invloed van het nieuwe beton op de mestsamenstelling bij van de Brandhof in Ede. Bovendien is bij van de Brandhof sprake van een lage ammoniak emissiefactor. Hierdoor heeft het verlagen van de putemissie door de installatie van mestbewerking nog slechts een beperkt effect op de totale emissie van de stal.

In het onderzoek zijn diverse factoren die van invloed kunnen zijn op de gemeten ammoniakemissiereductie onderzocht. Dit betreft:

- het verschil in gewicht van de dieren tussen de case en control afdeling;

- het verschil in ventilatiedebiet van de case en control afdeling;

- het verschil in de samenstelling van de mest tussen de case en control afdeling;

- het verdunnen van de mest door de installatie voor bewerking.

Uit de analyse van de meetresultaten blijkt dat de gemeten ammoniakemissiereductie niet toegeschreven kan worden aan bovengenoemde factoren.

Bij van de Beek wordt een methaanemissiereductie gemeten van $16 \%$. Er wordt geen lachgasemissiereductie gemeten. Bij Van de Brandhof wordt in de stal met de installatie voor mestbewerking een 35\% lagere methaanemissie en een $20 \%$ lagere lachgasemissie gemeten ten opzichte van de referentieafdeling. Gemiddeld is er bij beide bedrijven een methaanemissiereductie gemeten van $20 \%$ en een lachgasemissiereductie van $8 \%$.

Uit het onderzoek wordt geconcludeerd dat de gemeten emissiereductie van ammoniak, methaan en lachgas toegeschreven moet worden aan de invloed van de installatie voor mestbewerking. 


\title{
4.3 Abstract Van Vliet et al., 2006
}

\section{Referentie:}

P.C.J. van Vliet, J. Bloem, R.G.M. de Goede, Microbial diversity, nitrogen loss and grass production after addition of Effective Micro-organisms ${ }^{\circledR}(E M)$ to slurry manure, Applied Soil Ecology, Volume 32, Issue 2, June 2006, Pages 188-198, ISSN 0929-1393, http://dx.doi.org/10.1016/j.apsoil.2005.07.001.

(http://www.sciencedirect.com/science/article/pii/S092913930500123X)

\begin{abstract}
:
In this study, we used a DNA fingerprinting technique (PCR-DGGE) to investigate if bacteria present in an activated EM suspension (EM-A) were able to maintain or reach significant relative abundances after addition to slurry manure. We also investigated effects of the addition of EM-A to slurry manure on nitrogen losses from the manure and grass biomass production after application of the manure as

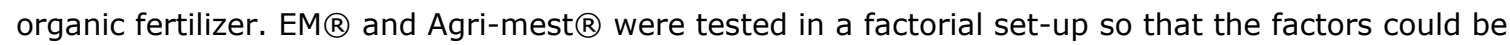
distinguished. Effective Organisms (EM) is a mixture of several effective, disease-depressing microorganisms. Agri-mest contains energized minerals, which will influence biochemical processes occurring in the manure.

Different EM-stocks, and EM-Active suspensions prepared by different users showed large variation in bacterial community structure and, thus, low reproducibility. Through the addition of Agri-mest to the slurry manure, loss of inorganic nitrogen from the slurry manure appeared to be reduced. Moreover, after application of such Agri-mest slurry as an organic fertilizer, nitrogen uptake by grass was reduced. Addition of EM-A had no measurable effects on the bacterial diversity and the chemical composition of the slurry manure. In a pot experiment, also no effects of EM on nitrogen uptake and grass biomass production were recorded.
\end{abstract}

Keywords: Bacterial diversity; Slurry manure; Manure quality; Effective Micro-organisms; DNA fingerprinting 


\title{
4.4 Abstract Van der Stelt et al., 2007
}

\section{Referentie:}

B. Van der Stelt, E.J.M. Temminghoff, P.C.J. Van Vliet, W.H. Van Riemsdijk, Volatilization of ammonia from manure as affected by manure additives, temperature and mixing, Bioresource Technology, Volume 98, Issue 18, December 2007, Pages 3449-3455, ISSN 0960-8524, http://dx.doi.org/10.1016/j.biortech.2006.11.004.

(http://www.sciencedirect.com/science/article/pii/S0960852406005918)

\begin{abstract}
:
Ammonia (NH3) volatilization decreases the $\mathrm{N}$-nutrient value of livestock manure slurries and can lead to soil acidification and eutrophication problems. In this study the effect of three manure additives

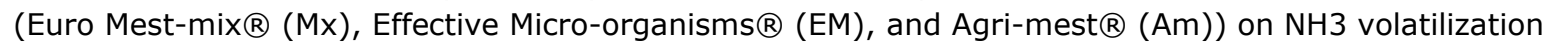
at three temperatures $\left(4,20\right.$, and $\left.35^{\circ} \mathrm{C}\right)$ was investigated. The manufacturers claim that Mx contains absorbing clay minerals and that applying Am and EM to slurry will reduce nitrogen losses, most likely by enhancing the biodegradation of manure slurry. Furthermore, the effect of mixing slurry on NH3 volatilization has been investigated. Ammonia volatilization increased with increasing temperature and mixing of the slurries. However, at $35^{\circ} \mathrm{C}$ mixing of manure reduced $\mathrm{NH} 3$ emissions compared to nonmixing, which is related to a reduced crust resistance to gaseous transport at higher temperatures for non-mixing. Moreover, mixing introduces oxygen into the anaerobic slurry environment which will slow down microbial activity. The use of additives did not change manure characteristics $(\mathrm{pH}$, dry matter, Ntotal, Nmineral, $\mathrm{C} / \mathrm{N}$, and $\mathrm{C} /$ Norganic) and did not result in a significant $(p<0.05)$ decrease in $\mathrm{NH} 3$ emissions, except that at $4^{\circ} \mathrm{C}$ and no mixing a significant decrease of $34 \%$ in $\mathrm{NH} 3$ volatilization was observed, when Am and EM together, were applied to slurry.
\end{abstract}

Keywords: Ammonia volatilization; Additives; Cattle slurry 
4.5 Patent WO 2014/104883 A1, verleend aan aanvrager / leverancier (25 pagina's)

Titel: New bacteria and consortia for the reduction of amonia and/or methane emission in manure or soil 


\section{(12) INTERNATIONAL APPLICATION PUBLISHED UNDER THE PATENT COOPERATION TREATY (PCT) (19) World Intellectual Property \\ Organization \\ International Bureau \\ (43) International Publication Date 3 July 2014 (03.07.2014)

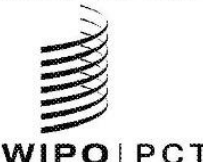 \\ WIPOIPCT

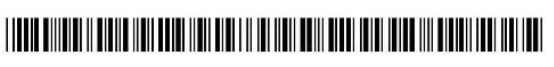 \\ (10) International Publication Number WO 2014/104883 A1}

(51) International Patent Classification:

C12N 1/20 (2006.01) CO2F 3/34(2006.01)

C12R 1/01 (2006.01) A01C 3/00(2006.01)

(21) International Application Number:

PCT/NL2013/050949

(22) International Filing Date:

(25) Filing Language:

23 December 2013 (23.12.2013)

(26) Publication Language

(30) Priority Data:

201007431 December 2012 (31.12.2012)

English

English

NL JP Piaam (NL).

(72) Inventor: JOUSTRA, Rinze; Buren 4, NL-8756 JP Piaam (NL).

(74) Agents: VAN SOMEREN, Petronella Francisca Hendrika Maria et al.; Sweelinckplein 1, NL-2517 GK Den Haag (NL).

(81) Designated States (unless otherwise indicated, for every kind of national protection available): $\Lambda \mathrm{E}, \Lambda \mathrm{G}, \mathrm{AL}, \Lambda \mathrm{M}$, $\mathrm{AO}, \mathrm{AT}, \mathrm{AU}, \mathrm{AZ}, \mathrm{BA}, \mathrm{BB}, \mathrm{BG}, \mathrm{BH}, \mathrm{BN}, \mathrm{BR}, \mathrm{BW}, \mathrm{BY}$,
$\mathrm{BZ}, \mathrm{CA}, \mathrm{CH}, \mathrm{CL}, \mathrm{CN}, \mathrm{CO}, \mathrm{CR}, \mathrm{CU}, \mathrm{CZ}, \mathrm{DF}, \mathrm{DK}, \mathrm{DM}$, DO, DZ, EC, EE, EG, ES, FI, GB, GD, GE, GH, GM, GT, HN, HR, HU, ID, IL, IN, IR, IS, JP, KE, KG, KN, KP, KR, KZ, LA, LC, LK, LR, LS, LT, LU, LY, MA, MD, ME, MG, MK, MN, MW, MX, MY, MZ, NA, NG, NI, NO, NZ, OM, PA, PE, PG, PH, PL, PT, QA, RO, RS, RU, RW, SA, SC, SD, SE, SG, SK, SL, SM, ST, SV, SY, TH, TJ, TM, TN, TR, TT, TZ, UA, UG, US, UZ, VC, VN, ZA, ZM, ZW

84) Designated States (unless otherwise indicated, for every kind of regional protection available): ARIPO (BW, GH, GM, KE, LR, LS, MW, MZ, NA, RW, SD, SL, SZ, TZ, UG, ZM, ZW), Eurasian (AM, $\Lambda Z, B Y, K G, K Z, R U, T J$, TM), European (AL, AT, BE, BG, CH, CY, CZ, DE, DK,
EE, ES, FI, FR, GB, GR, HR, HU, IE, IS, IT, LT, LU, LV, EE, ES, FI, FR, GB, GR, HR, HU, IE, IS, IT, LT, LU, LV,
MC, MK, MT, NL, NO, PL, PT, RO, RS, SE, SI, SK, SM, TR), OAPI (BF, BJ, CF, CG, CI, CM, GA, GN, GQ, GW, KM, ML, MR, NE, SN, TD, TG)

Published:

- with international search report (Art. 21(3))

- before the expiration of the time limit for amending the claims and to be republished in the event of receipt of amendments (Rule 48.2(h))

(54) Title: NEW BACTERIA ANID CONSORTIA FOR THE, REDUCTION OF AMONIA AND/OR METHANE FMISSION IN MANURE OR SOIL

Figure $1 \mathrm{~A}$

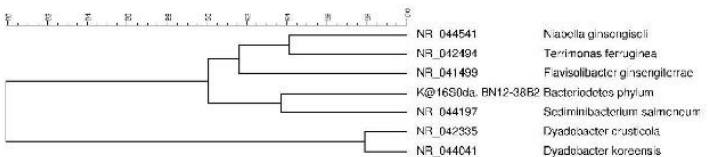

57) Abstract: The invention is related to a new bacterium comprising a partial 16S rDNA nucleic acid sequence having more than $85 \%$ sequence identity to the sequence presented as SEQ ID NO:1, or the complement thereof and a consortium of micro-organisms $85 \%$ sequence identity to the improving manure or soil. 
New Bacteria and Consortia for the reduction of ammonia and/or methane emission in manure or soil

This invention is related to new bacteria, a consortium comprising these bacteria and the use of the consortium for reduction of ammonia and/or methane emission in manure.

Manure is organic matter and can be used as organic fertilizer in agriculture. Manure contributes to the fertility of the soil by adding organic matter and

10 nutrients, such as nitrogen, that are trapped by bacteria in the soil. Manure contains nitrogen (N) in inorganic and organic forms. Organic $\mathrm{N}$ is not available for crop growth until it is mineralized to ammonium (NH4+). Ammonium $N$ is fairly building and available for plant uptake, but a

15 portion is immobilized by microbial biomass and nitrifying bacteria convert $\mathrm{NH} 4+$ to nitrate (NO3-) which is subject to loss by leaching or denitrification and subsequent loss to the atmosphere. Volatile ammonia (NH3) in manure is transformed from $\mathrm{NH} 4+$ and can be lost to the atmosphere

20 after land application. Nitrogen lost to the atmosphere is not available for crop production. In addition, ammonia (NH3) emission from livestock production causes undesirable environmental effects. Besides the undesirable effect of NH3, manure also comprises methane (CH4). Methane is a

25 greenhouse gas and it is generally known that the emission of $\mathrm{CH} 2$ in the atmosphere should be reduced.

There is thus a need for a product that can be added to manure which can improve the quality of manure by providing an increase amount of nutrients, such as nitrogen, available 30 to crops.

There is a need for a product that can be added to manure which can provide an improved fertilizing quality to crop plants. 
In addition there is a need for a product that can be added to manure which helps to reduce the ammonia and/or methane emission in manure or in soil.

It is an object of this invention, amongst other

5 objects, to provide a consortium of micro-organisms which can be added to manure, for improving the quality of manure.

Yet, it is an other object of this invention to provide a consortium of micro-organisms which can process the manure so that ammonia and/or methane emission is reduced.

Yet, it is an other object of this invention to provide a consortium of micro-organisms that can be used for improving manure so that the nitrogen availability to plants increases.

Yet, it is an object of this invention to provide a

15 consortium of micro-organims which can be added to the soil, for improving soil fertility.

It is an other object of this invention, to provide a bacteria, which forms part of the consortium that can provide the above objects.

This object, amongst other objects, is met, at least partially, if not completely by the bacteria or consortium as claimed in the annex.

Especially, this object is met at least partially, if not completely by a bacterium comprising a partial $16 \mathrm{~S}$ rDNA

25 nucleic acid sequence having more than 85\% sequence identity to the sequences presented as SEQ ID NO:1, or the complement thereof. The inventor surprisingly found a new bacterium that resides in a consortium. The bacterium in the consortium and the consortium provide an improved quality to 30 manure in a way that less ammonia and/or methane is emitted from manure, when compared with manure where this consortium is not added. 
The partial 16S rDNA can be found using the 16S rDNA sequencing method as described in Hall, L., Doerr, K.A., Wohlfiel, S.L., Roberts, G.D., 2003. Evaluation of the Microseq system for identification of mycobacteria by $16 \mathrm{~S}$

5 ribosomal DNA sequencing and its integration into a routine clinical mycobacteriology laboratory, J. Clinic. Microbiol. 4, 1447-1453, of which the reference is incorporated in its entirety. The PCR was performed on bacterial suspension with the following primers (sequences in $5^{\prime}$ to $3^{\prime}$ direction)

$1016 \mathrm{~S} 500 \mathrm{~F}$ (tggagagtttgatcctggctcag) and 16S500R (taccgcggetgctggcac).

Sequence identity, as used herein, is defined as the number of identical consecutive aligned nucleotides, or amino acids, over the full length of the present sequences

15 divided by the number of nucleotides, or amino acids, of the full length of the present sequences and multiplied by $100 \%$. For example, a sequence with $80 \%$ identity to SEQ ID No. 1 comprises over the total length of 550 amino acids of SEQ ID No. 1440 identical aligned consecutive amino acids, i.e.,

$20440 / 550 * 100 \%=80 \%$.

The invention is related to a newly found bacterium. A phylogenetic tree has been measured using the UPGMA algorithm (Unweighted Pair Group Method with Arithmetic Means) provided by the program of Bionumerics (from Applied

25 Maths) measuring the PCT ribotype band sizes. It was found that the bacterium having a $16 \mathrm{~S}$ rDNA sequence comprising SEQ ID NO: 1 belongs to the genus Bacteriodetes. In one embodiment, the invention is related to a bacterium wherein the bacteria is a bacteriodetes sp. In another embodiment the invention is related to a bacterium wherein the bacterium is as is deposited at CBS under the deposit no CBS 134116, as deposited at CBS (Centraal Bureau voor Schimmelcultures on 27 December 2012 
under the Budapest Treaty), wherein CBS 134116 is a bacteriodetes.

In yet another embodiment, the bacterium has a sequence identity which is at least 85, 86, 87, 88, 89, 90, 91, 92,

$593,94,95,96,97,98,99,100 \%$ identical with the sequence as is presented as SEQ ID NO:1. In a preferred embodiment, the bacterium has a sequence identity which is at least $99.7,99.8,99.9,100 \%$ identical with the sequence as is presented as SEQ ID NO: 1 .

In one aspect, the invention is related to a consortium comprising a bacterium as described above. The consortium may further comprise yeast of the genus Candida, preferably Candida boidinii C. Ramírez and/or Candida ethanolica Rybárová, Stros \& Kocková-Kratochvílová, and/ or may further

15 comprise the bacteria Lactobacillus rhamnosus/casei, Acetobacter pasteurianus/lovaiensus and/ or Rhodococcus facians/yunnanensis.

The consortium may further comprise other lactic acid bacteria and other acetic acid bacteria.

In one embodiment, the consortium comprises one or more bacteria selected from the group consisting of Lactobacillus rhamnosus, Lactobacillus casei, Lactobacillus ghanensis, Lactobacillus paracasei, Bacillus subtilis sensu stricto, Bacillus amyloliquefaciens, Bacillus atrophaeus, Bacillus

25 Vallismorits, Bacillus mojavensis, Bacillus tequilensis, Bacillus siamensis, and Bacillus methylotrophicus. In a preferred embodiment, the consortium comprises all these bacteria.

In one embodiment, the consortium improves manure and

30 reduces the emission of ammonia and/or methane compared with manure where no consortium according to this invention is added. With manure is understood excrements of animals, and can be in a semi liquid state, such as slurry. 
In one embodiment, the consortium improves soil and reduces the emission of ammonia and/or methane compared with soil where no consortium according to this invention is added. With soil is understood the loose covering of mineral

5 particles that thinly overlie the earth's surface, such as the soil covering farm lands where crops are grown.

In another embodiment, the invention is related to a consortium as is deposited at the CBS, and has the deposit number CBS134115 as deposited at Centraal Bureau for

10 Schimmelcultures.

In another embodiment, the consortium according to the invention further comprises a saccharide, preferably a monosaccharide and/or disaccharide. It is thought that the saccharide provides an environment for the bacteria and

15 yeast in the consortium, which provides a composition of the bacteria and yeasts with a ratio in a way that in manure the production of ammonia and/or methane decreases. It is thought that the consortium provides an environment in manure, which is not favourable for ammonia producing

20 bacteria.

In yet another embodiment, the saccharide is derived from cane source or beat source and is preferably a cane molasses.

In another aspect, the invention is related to the use

25 of SEQ ID NO:1 for detecting or identifying a bacterium having the nucleic acid sequence or at least $85 \%$ sequence identity with SEQ ID NO: 1 .

In another aspect, the invention is related to a consortium of micro-organisms that comprises micro-organisms

30 that provide reduction of the emission of ammonia and/or methane (NH3) in manure, as can be found in a consortium as is deposited at CBS under the deposit no of CBS 134115. 
In another aspect, the invention is related to the use of a bacterium according to the invention or a consortium according to the invention, for the reduction of nitrogen in manure. The use can, for example, be performed by spraying a

5 solution comprising the bacterium or the consortium according to the invention on manure. This can, for example, be performed using a method and product as described in the patent application NL 2009019 of which the reference is incorporated in its entirety.

The manure is preferably animal manure, coming from e.g. pigs, cows, poultry or horses.

In another aspect, the invention is related to the use of a bacterium according to the invention or a consortium according to the invention, for the reduction of nitrogen in

15 soil. The use can, for example, be performed by spraying a solution comprising the bacterium or the consortium according to the invention on soil.

In another aspect the invention is related to a method for reducing the emission of ammonia and/or methane in

20 manure comprising adding the bacteria or the consortium according to the invention to manure and incubating said bacteria or consortium for a sufficient time allowing to reduce the formation of ammonia and/or methane in the manure.

In another aspect the invention is related to a method for reducing the emission of ammonia and/or methane in soil comprising adding the bacteria or the consortium according to the invention to soil and incubating said bacteria or consortium for a sufficient time allowing to reduce the

30 formation of ammonia and/or methane in the soil.

Another aspect according to the invention is the use of manure according to the invention as an organic fertilizer. The consortium or the bacteria in the consortium 
7

according to the invention contribute to a reduced emission of ammonia. It is thought that more nitrogen is in a phase that can be used by plants, such as crop plants. It is surprisingly found that the consortium and the bacteria

5 according to the invention can be used for improving manure or soil and that beside the reduction of ammonia is obtained, also the fertilizing properties of the manure or soil according to the invention is improved.

The advantages and embodiments as described for several

10 aspects in the invention can be valid for the other aspects according to the invention.

The present invention will be further described in detail in the following example of preferred embodiments of the invention.

15

\section{Figure 1}

Dendrograms of Cluster analysis based on pairwise similarities of the new found bacterium Bacteroidetes phylum (figure 1A) (CBS 134116). The numbers above show the amount

20 of similarity measured using the similarity-based clustering using the method Unweighted pair-grouping (UPGMA)

\section{Example 1}

\section{Test of ammonia emission in manure of a pig farm}

In two livestock buildings for pigs, measurement of ammonia emission have been performed. In one building, the device as described in patent application NL2009019 has been used to treat the slurry coming from the pigs. The consortium as deposited at CBS under no. CBS 134115, has been sprayed on the slurry excreted by the pigs in building 
1. Building 2 comprised slurry that was not treated with the consortium.

In each building 80 pigs were kept and the measurement was performed over a period of 12 weeks. Each day a

5 composition comprising the consortium is sprayed in building 1 during 12 weeks. NH3 emission has been measured during 24 hours using the norm NEN 2826 (NEN 2826, 1999: Luchtkwaliteit. Uitworp door stationaire puntbronnen. Monsterneming en bepaling van het gehalte aan gasvormig

10 ammoniak) by taking samples using a gas washing bottle comprising an absorption liquid. The ammonia measurements were performed by performing an absorption method and wet chemical analysis.

The samples were taken during several cycli of weeks of

15 the pigs and during several months of the year. Table 1 shows the results of the emission of ammonia. The manure that was treated with the consortium as deposited at CBS under no. CBS 134115 showed an average decrease of 35\% ammonia emission in the manure compared with the manure from

20 building 2 . The measurements were taken in several seasons (summer, winter and autumn) and also on different growing stages of the pigs (12 weeks in total, and each period of two weeks counts for 1 stage).

In the setup of the measurement, the amount of animals, the

25 ages and the weight of the animals were in both animal buildings similar.

Table 1

\begin{tabular}{|c|c|c|c|}
\hline \multicolumn{4}{|c|}{ Emission of ammonia per year in $\mathrm{kg} / \mathrm{animal}$} \\
\hline St: 2.9 & P ilgget: & 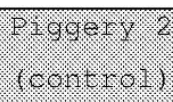 & 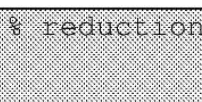 \\
\hline 4 & 6,2 & 11,3 & 45 \\
\hline 2. & 3., 5 & 3. 5 & 3. \\
\hline
\end{tabular}


9

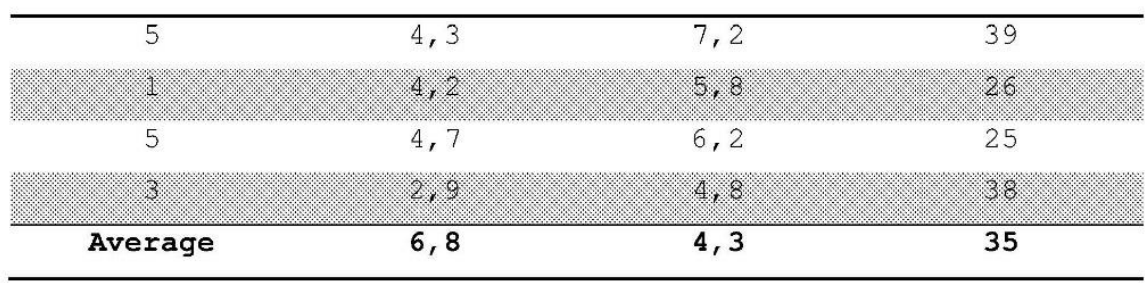

Example 2

Test of methane emission in manure for a pig form

5

A similar setup as in example 1 was performed. The methane was measured by taking a sample and using the lung method according to the norm NEN-EN, during $24 \mathrm{~h}$.

There was an average methane reduction of $19 \%$ found in 10 two different farms.

Table 2 shows the results in one farm of the methane measurement in piggery 1, where the consortium mixture was added to the manure, compared with piggery 2 (control), where no consortium mixture was added.

15

\begin{tabular}{|l|c|l|l|}
\hline \multicolumn{1}{|l|}{ Table 2 } & Piggery 1 & Piggery 2 & Stage \\
\hline Methane ppm & 14,8 & 17,8 & 1 (summer) \\
\hline $\begin{array}{l}\text { Methane } \\
\text { emission/animal/year }\end{array}$ & 1,0 & 1,6 & 1 (summer) \\
\hline
\end{tabular}


10

\begin{tabular}{|l|c|c|c|}
\hline (kg/animal/year) & 37,0 & 52,6 & 2 (winter) \\
\hline Methane ppm & 1,9 & 3,9 & 2 (winter) \\
\hline $\begin{array}{l}\text { Methane } \\
\text { erission/animal/year } \\
\text { (kg/animal/year) }\end{array}$ & 32 & 60,6 & 3 (spring) \\
\hline $\begin{array}{l}\text { Methane ppm } \\
\begin{array}{l}\text { Methane } \\
\text { erission/animal/year } \\
\text { (kg/animal/year) }\end{array}\end{array}$ & 2,1 & 4,3 & 3 (spring) \\
\hline
\end{tabular}

\section{Example 3}

\section{Identification of consortium}

A sample of the consortium as is deposited at CBS under the deposit no of NR CBS 134115 was analyzed in order to identify its components. The analysis was performed by $\mathrm{BCCM}^{\mathrm{IM}} / \mathrm{LMG}$ Identification Service in Gent, Belgium.

An aliquot of the sample (a few drops) was taken aseptically and was uniformly spread on:

- LMG medium nr. 66 (MRS) and incubated anaerobically at $37^{\circ} \mathrm{C}$ for 1 day,

- LMG medium nr. 37 (RCM) and incubated anaerobically at ${ }^{\circ} \mathrm{C}$ for 1 day,

- LMG medium nr. 13 and incubated aerobically at $28^{\circ} \mathrm{C}$ for 1 day, 
- LMG medium nr. 185 (TSA) and incubated aerobically at $28^{\circ} \mathrm{C}$ for 2 days.

On the different media, different colony types were observed which were purified for further analyses. subjected to DNA fingerprinting using $A F L P^{\mathrm{TM}}$. AFLP ${ }^{\mathrm{TM}}$ is a PCR based technique for whole genome fingerprinting via the selective amplification of restriction fragments (Vos et al., Nucleic Acids Research 23: 4407-4414 (1995)). The

10 primer combination E01/T11 (Keygene) was used.

Clusteranalysis of the AFLP ${ }^{\mathrm{TM}}$ DNA fingerprint with the reference $\mathrm{AFLP}^{\mathrm{TM}}$ DNA fingerprints of the lactic acid bacteria taxa (including bifidobacteria) identified the cultures as Lactobacillus rhamnosus (t1), Lactobacillus casei (t2),

15 Lactobacillus ghanensis (t6), and Lactobacillus paracasei (t7). It should be noted that literature data indicate that the type strain of Lactobacillus casei belongs to the species Lactobacillus zeae. However, the judicial commission of the international committee on systemics of prokaryotes

20 ruled that the name Lactobacillus zeae should not be used (Int. J. Syst. Evol. Microbiol. 58: 1764-1765, (2008)).

Two of the purified colonies ( $t 3$ and $t 4$ ) were subjected to partial 16S rDNA sequence analysis. Total DNA was prepared according to the protocol of Niemann et al. ( $\mathrm{J}$.

25 Appl. Microbiol. 82: 477-484 (1997)). A fragment of the 16S rDNA gene (corresponding to the positions 8-1541 in the Escherichia coli numbering system) was amplified by PCR using conserved primers. The PCR product was purified using the Nucleofast $\otimes^{8} 96$ PCR Clean-up kit (Macherey-Nagel,

30 Germany). Sequencing reactions were performed using the BigDye X XerminatorT Purification Kit (Applied Biosystems, 
USA). Sequence assembly was performed by using the software package BioNumerics (Applied Maths, Belgium).

Phylogenetic analysis was performed using the software package Bionumerics (Applied Maths, Belgium) after including

5 the consensus sequence in an alignment of small ribosomal subunit sequences collected from the international nucleotide sequence library EMBL.

A similarity matrix was created by homology calculation with a gap penalty of $0 \%$; unknown bases were discarded. In

10 this way, a similarity of $\geq 97 \%$, being significant for possible species identification, was found with several validly described Bacillus species. However, the high sequence similarities (99.1-100\%, based on a partial sequence) obtained with all validly described species of the

15 B.subtilis-complex (a set highly related species, currently encompassing $B$. subtilis sensu stricto, $B$. amyloliquefaciens, $B$. atrophaeus, B. vallismorits, $B$. mojavensis, $B$. tequilensis, $B$. siamensis, and $B$. methylotrophicus), indicate that that one of the cultures

20 (t3) belongs to one of these species. For the other culture, a similarity of $\geq 97 \%$, being significant for possible species identification, was found with several validly described Lactobacillus species. However, the high sequence similarities (99.6-99.7) based on a partial sequence)

25 obtained with the type strains of $L$. casei (99.7\%) and $L$. zeae (99.6\%), indicate that this culture (t4) belongs to one of these species, in particular to L. casei.

For a further analysis of the sample, an aliquot was

30 taken aseptically and a serial (decimal) dilution in 
physiological water was made. Aliquots of $0.1 \mathrm{ml}$ were uniformly spread on:

- LMG medium nr. 185 (TSA) and incubated aerobically at $28^{\circ} \mathrm{C}$ for 3 days.

5 One additional colony type (t8) was observed and purified for further analysis by partial 16S rDNA sequence analysis as described above. In this way, a similarity of 297\%, being significant for possible species identification, was found with several validly described Lactobacillus

10 species. however, the high sequence similarities (99.699.9\%, based on a partial sequence) obtained with the type strains of both subspecies of $L$. paracasei, indicate that that this culture (t8) belongs to this species. 
$<110\rangle$ Rinagro BV

<120> New bacteria for improving manure

$<130\rangle 2 \mathrm{NJ} 69$

$10<160\rangle$

$<170>$ BISSAP 1.2

$<210\rangle$

$15<211>498$

$<212>$ DNA

<213> Bacteroidetes <phylum>

$<220>$

$20<221>$ source

$<222>1 \ldots 498$

$<223>$ Jorganism="Bacteroidetes <phylum>" /mol_type-"unassigned DNA"

$25<400\rangle$

cctggctcag gatgaacgct agcggcaggc ttaatacatg caagtcgtgg ggcagcatga 60

atgtagcaat acatttgatg gcgaccggca aacgggtgcg gaacacgtac acaaccttcc $\quad 120$

30 Lataagtggg gaatagccca gagaaattlg gatlaatacc ccglaacata acgatglgge 180 atcacattgt tattatagct tcggcgctta ttgatgggtg tgcggctgat tagatagttg 240

35 gcggggtaac ggcccaccaa gtctacgatc agtagctgat gtgagagcat gatcagccac 300 acgggcactg agacacggge ccgactccta cgggaggcag cagtaaggaa tattggtcaa 360 tggacgcaag tctgaaccag ccat.gccgcg tgaaggatta aggtcctctg gatt.gtaaac 420

40 Llcllltalc Lgggacgaaa aaaggcgatl cllcglcacl lgacgglacc agalgaalaa 480 $\begin{array}{ll}\text { gcaccggeta actccgtg } & 498\end{array}$ 


\section{Claims}

1. A bacterium comprising a partial $16 \mathrm{~S}$ rDNA nucleic acid sequence having more than $85 \%$ sequence identity to the

5 sequence presented as SEQ ID NO:1, or the complement thereof.

2. Bacterium according to claim 1, wherein the bacterium has more than $99.6 \%$ sequence identity to the

10 sequence presented as SEQ ID NO:1, or the complement thereof.

3. Bacterium according to claim 1 or 2, wherein the bacteria is a bacteriodetes sp.

15

4. Bacterium according to claim 1-3, wherein the bacterium is as is deposited at CBS under the deposit no CBS 134116 .

20

5. Bacterium according to claim 1-4 having the sequence presented aS SEQ ID NO:1, or the complement thereof.

6. Consortium of micro-organisms for improving manure or soil comprising a bacterium according to claim 1-5.

25

7. Consortium according to claim 6, wherein the consortium further comprises a saccharide, preferably a monosaccharide and/or disaccharide. saccharide is derived from a cane source or beat source and is preferably a cane molasses. 
9. Use of SEQ ID NO:1 for detecting or identifying a bacterium having the nucleic acid sequence or at least $85 \%$ sequence identity to the sequence presented as SEQ ID NO:1.

10. A consortium of micro-organisms that comprises micro-organisms that reduce emission of ammonia and/or methane, as can be found in a consortium as is deposited at CBS under the deposit no of NR CBS 134115. 10, comprising one or more bacteria selected from the group consisting of Lactobacillus rhamnosus, Lactobacillus casei, Lactobacillus ghanensis, Lactobacillus paracasei, Bacillus subtilis sensu stricto, Bacillus amyloliquefaciens, Bacillus

15 atrophaeus, Bacillus vallismorits, Bacillus mojavensis, Bacillus tequilensis, Bacillus siamensis, and Bacillus methylotrophicus.

12. Consortium of micro-organisms according to claim

20 11, comprising the bacteria Lactobacillus rhamnosus, Lactobacillus casei, Lactobacillus ghanensis, Lactobacillus paracasei, Bacillus subtilis sensu stricto, Bacillus amyloliquefaciens, Bacillus atrophaeus, Bacillus vallismorits, Bacillus mojavensis, Bacillus tequilensis, 25 Bacillus siamensis, and Bacillus methylotrophicus.

13. Consortium of micro-organisms according to claim 10-12, comprising the consortium as is deposited at CBS under the deposit no CBS 134115.

30

14. Use of bacterium according to claim 1-5 or a consortium according to claim 6-8 or 10-13 for the reduction of ammonia/ and or methane emission in manure or soil. 
15. Use according to claim 14, wherein the manure is animal manure.

16. Manure comprising a bacteria according to claim 1-5 or a consortium according to claim6-8 or 10-13.

17. Method for reducing ammonia and/or methane in manure or soil comprising the steps of adding a bacteria

10 according to claim $1-5$ or a consortium according to claim 6 8 or 10-13 to manure or soil and incubating said bacteria or consortium for a sufficient time allowing to reduce the formation of ammonia and/or methane in the manure. fertilizer. 

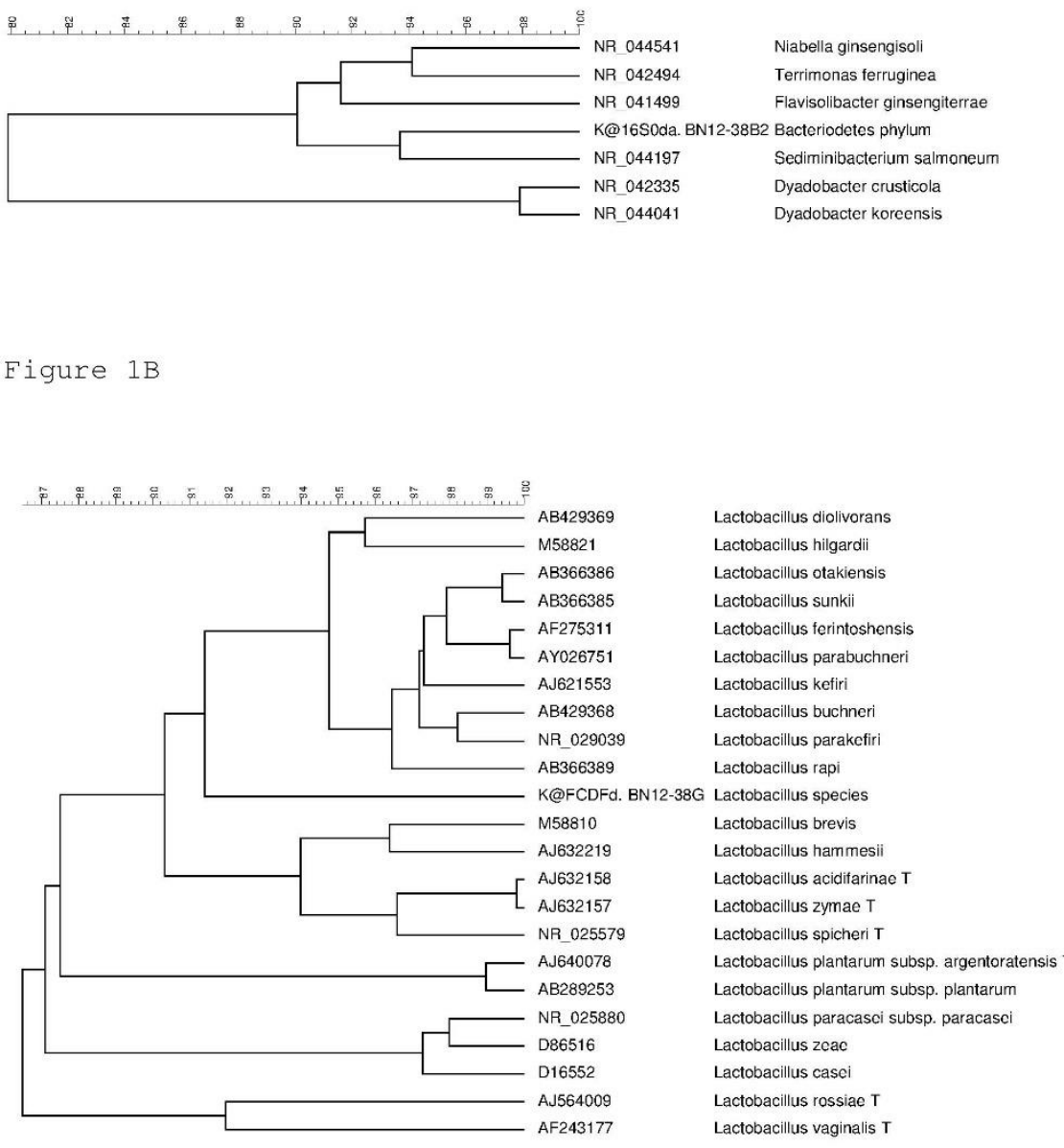
INTERNATIONAL SEARCH REPORT

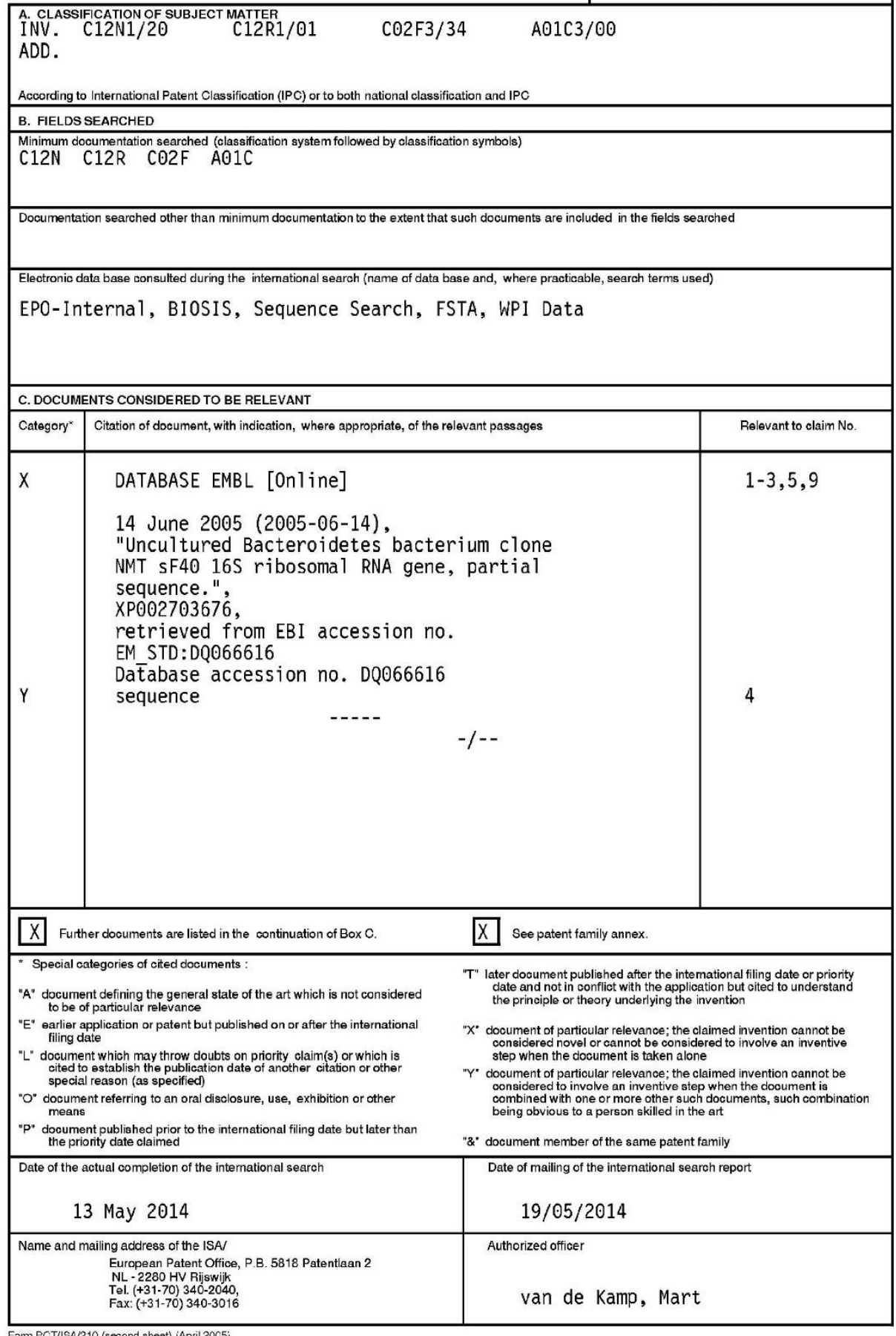


Box No. II Observations where certain claims were found unsearchable (Continuation of item 2 of first sheet)

This international search report has not been established in respect of certain claims under Article 17(2)(a) for the following reasons:

Claims Nos:

because they relate to subject matter not required to be searched by this Authority, namely:

2. $\square$ Claims Nos.

in relate to parts of the international application that do not comply with the prescribed requirements to such an extent that no meaningful international search can be carried out, specifically:

Claims Nos:

because they are dependent claims and are not drafted in accordance with the second and third sentences of Rule 6.4(a)

Box No. III Observations where unity of invention is lacking (Continuation of item 3 of first sheet)

This International Searching Authority found multiple inventions in this intemational application, as follows:

see additional sheet

1. As all required additional search fees were timely paid by the applicant, this international search report covers all searchable

2. As all searchable claims could be searched without effort justifying an additional fees, this Authority did not invite payment of additional fees.

3. As only some of the required additional search fees were timely paid by the applicant, this international search report covers only those claims for which fees were paid, specifically claims Nos. restricted to the invention first mentioned in the claims; it is covered by claims Nos:

Remark on Protest The additional search fees were accompanied by the applicant's protest and, where applicable, the payment of a protest fee.

$\square$ The additional search fees were accompanied by the applicant's protest but the applicable protest

fee was not paid within the time limit specified in the invitation.

X No protest accompanied the payment of additional search fees.

Form PCT/ISA/210 (continuation of first sheet (2)) (April 2005) 


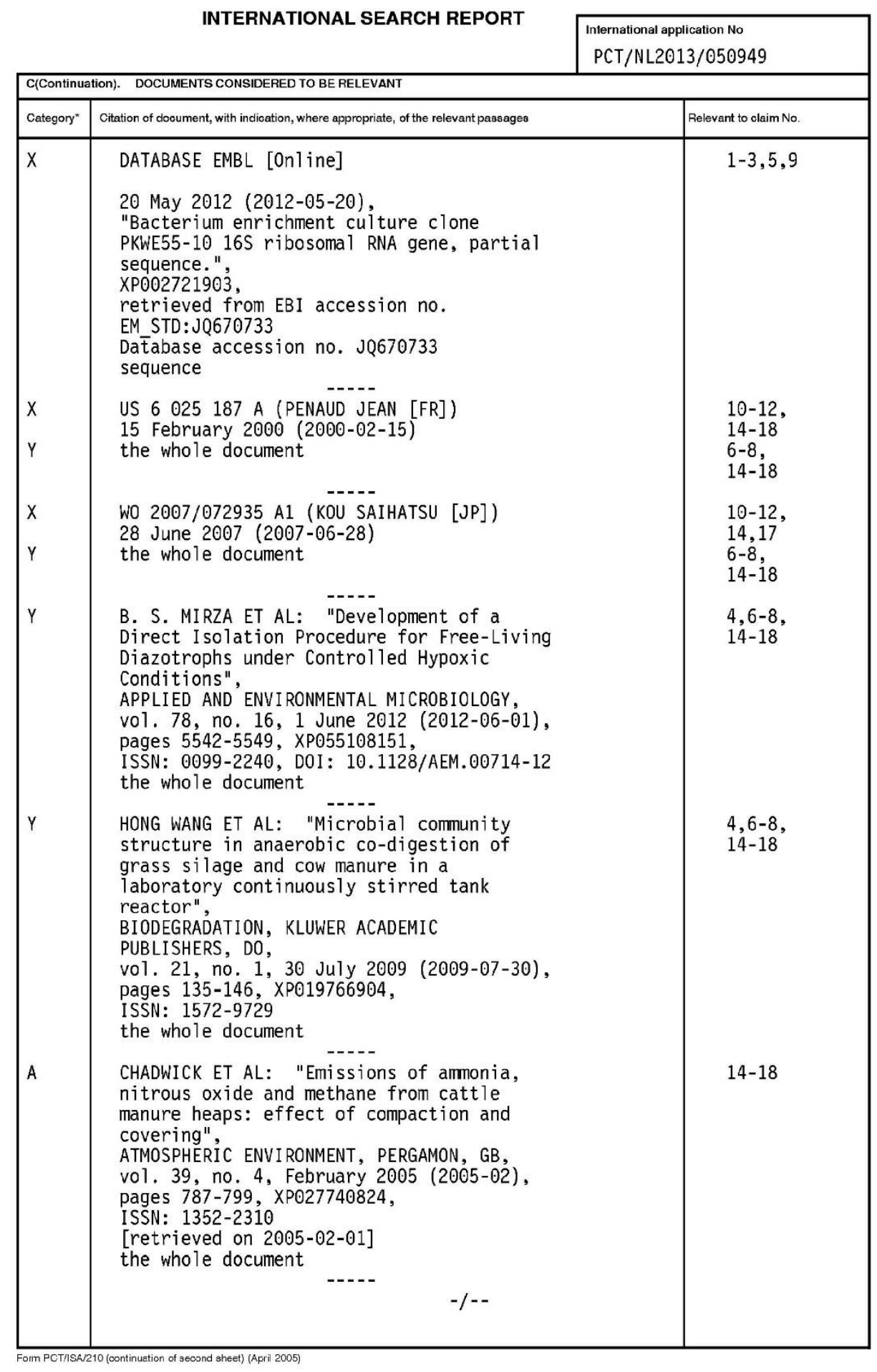




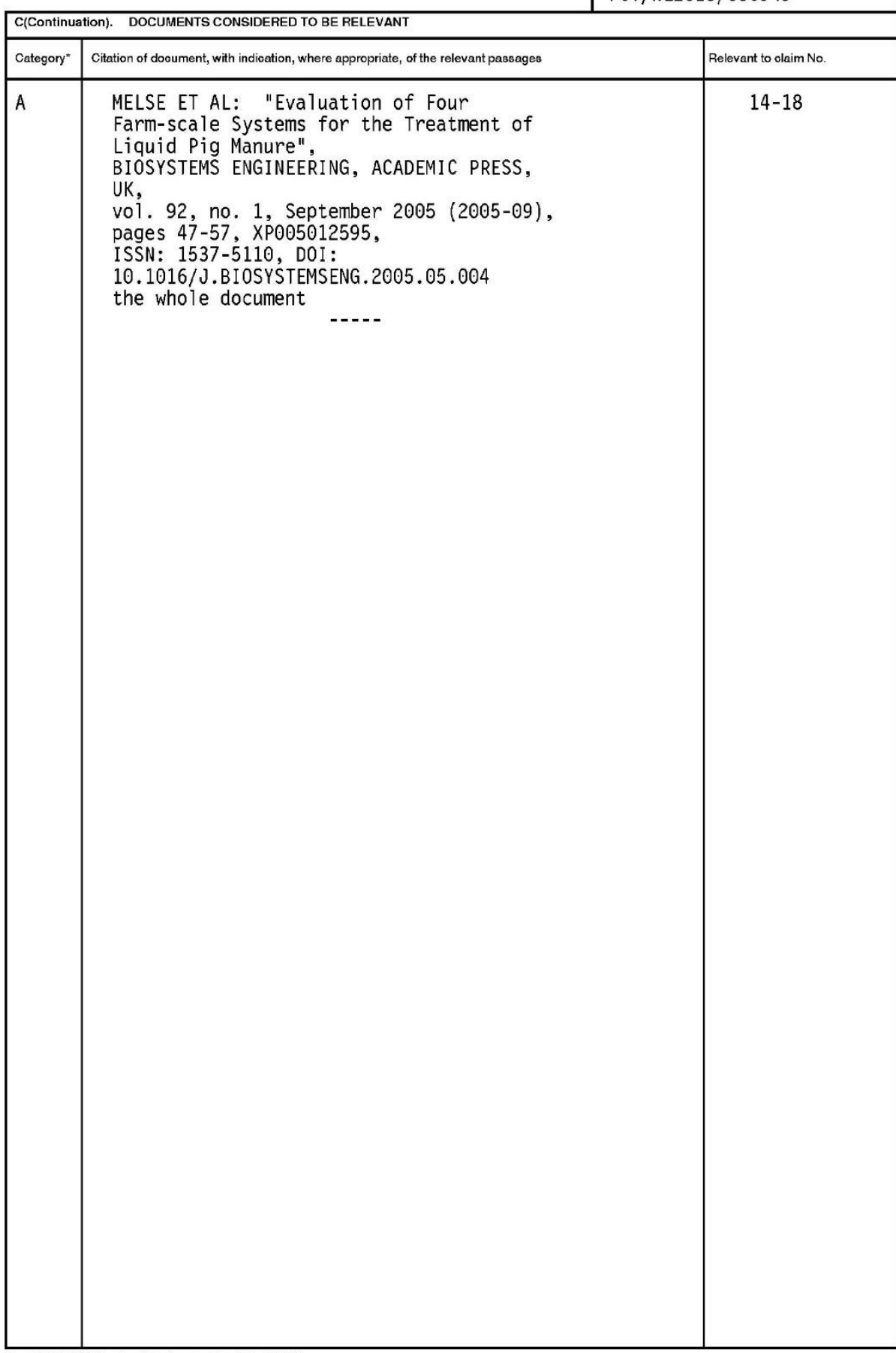


This International Searching Authority found multiple (groups of) inventions in this international application, as follows:

\section{1. claims: 1-9(completely); 14-18(partially)}

A bacterium comprising a partial 16S rDNA nucleic acid sequence having more than $85 \%$, pref. having more than $99.6 \%$, more pref. having $100 \%$ sequence identity to the sequence presented as SEQ ID N0:1, or the complement thereof, pref. a Bacteriodetes sp., pref. the bacterium as is deposited at CBS under the deposit no CBS 134116. Consortium of micro-organisms for improving manure or soil comprising said bacterium. Use of SEQ ID N0:1 for detecting or identifying a bacterium having the nucleic acid sequence or at least $85 \%$ sequence identity to the sequence presented as SEQ ID NO:1. Use of said bacterium or said consortium for the reduction of ammonia and/or methane emission in manure or soil. Manure comprising said bacterium or said consortium, and use thereof as an organic fertilizer. Method for reducing ammonia and/or methane in manure or soil comprising the steps of adding said bacterium or said consortium to manure or soil and incubating said bacterium or consortium for a sufficient time allowing to reduce the formation of ammonia and/or methane in the manure.

$$
\text { --- }
$$

\section{2. claims: 10-13(completely); 14-18(partially)}

A consortium of micro-organisms that comprises micro-organisms that reduce emission of ammonia and/or methane, as can be found in a consortium as is deposited at CBS under the deposit no of NR CBS 134115. Use of said consortium for the reduction of ammonia and/or methane emission in manure or soil. Manure comprising said consortium, and use thereof as an organic fertilizer. Method for reducing ammonia and/or methane in manure or soil comprising the steps of adding said consortium to manure or soil and incubating said consortium for a sufficient time allowing to reduce the formation of ammonia and/or methane in the manure. 


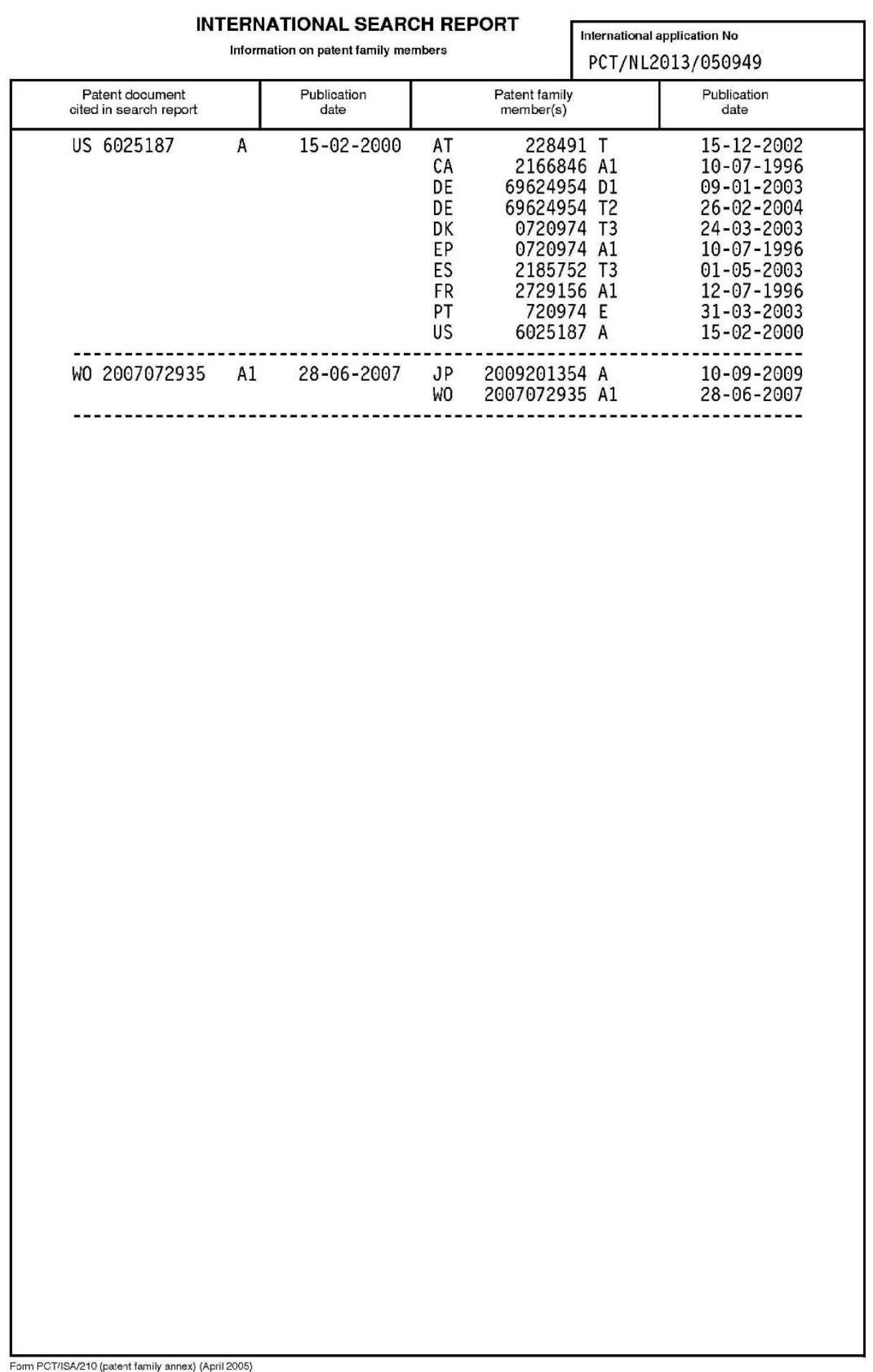



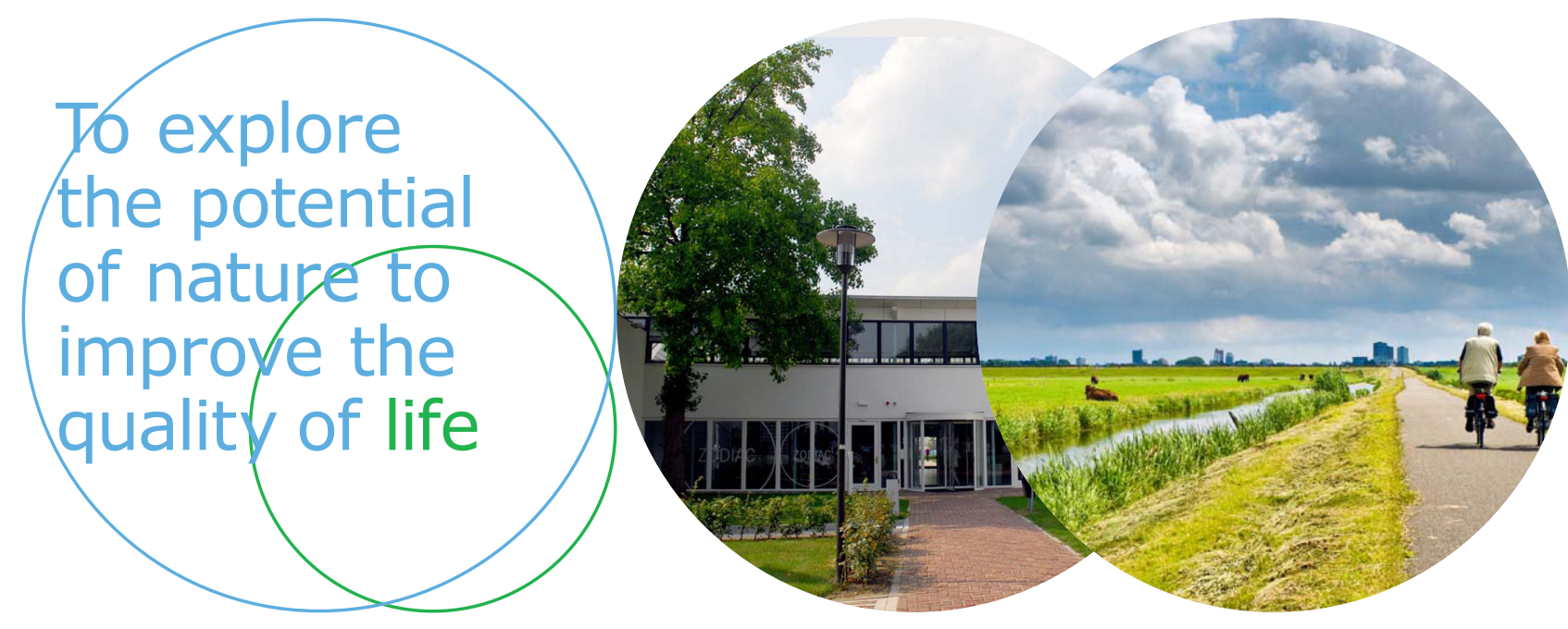

Wageningen Livestock Research Postbus 338

Wageningen Livestock Research ontwikkelt kennis voor een zorgvuldige en $6700 \mathrm{AH}$ Wageningen

T 0317483953

renderende veehouderij, vertaalt deze naar praktijkgerichte oplossingen en innovaties, en zorgt voor doorstroming van deze kennis. Onze wetenschappelijke E info.livestockresearch@wur.nl www.wur.nl/ livestock-research kennis op het gebied van veehouderijsystemen en van voeding, genetica, welzijn en milieu-impact van landbouwhuisdieren integreren we, samen met onze klanten, tot veehouderijconcepten voor de 21 e eeuw.

De missie van Wageningen University \& Research is 'To explore the potential of nature to improve the quality of life'. Binnen Wageningen University \& Research bundelen 9 gespecialiseerde onderzoeksinstituten van Stichting Wageningen Research en Wageningen University hun krachten om bij te dragen aan de oplossing van belangrijke vragen in het domein van gezonde voeding en leefomgeving. Met ongeveer 30 vestigingen, 6.500 medewerkers en 10.000 studenten behoort Wageningen University \& Research wereldwijd tot de aansprekende kennisinstellingen binnen haar domein. De integrale benadering van de vraagstukken en de samenwerking tussen verschillende disciplines vormen het hart van de unieke Wageningen aanpak. 